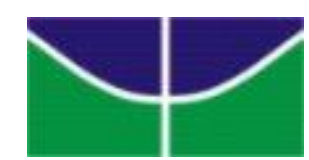

Universidade de Brasília - UnB

Faculdade de Direito

LUIZA KHARMANDAYAN

\begin{abstract}
A RELAÇÃO ENTRE O DIREITO E A TEORIA ECONÔMICA NA JURISPRUDÊNCIA DO CADE SOBRE TABELAS MÉDICAS
\end{abstract}

Brasília

2015 
UNIVERSIDADE DE BRASÍLIA

FACULDADE DE DIREITO

\section{A RELAÇÃO ENTRE O DIREITO E A TEORIA ECONÔMICA NA JURISPRUDÊNCIA DO CADE SOBRE TABELAS MÉDICAS}

Autora: Luiza Kharmandayan

Orientadora: Prof. Dra. Ana Frazão

Dissertação apresentada como requisito parcial à obtenção do grau de Mestre, no Programa de Pós-Graduação da Faculdade de Direito da Universidade de Brasília, linha de pesquisa "Globalização, Transformações do Direito e Ordem Econômica”.

Brasília, 2015. 


\section{Resumo}

O objetivo do presente trabalho é analisar a relação entre direito e teoria econômica na aplicação do direito concorrencial brasileiro. Para tanto, utiliza-se a jurisprudência do Cade sobre tabelamento sugestivo ou impositivo de preços de honorários médicos, mais comumente referido como tabelas médicas. A análise dessa jurisprudência, porém, é precedida por um referencial teórico o qual começa por fazer uma breve retrospectiva histórica do controle antitruste, desde de sua origem, tendo o Sherman Act como marco. Após apresentar como o papel da teoria econômica e do direito, no controle antitruste, variaram ao longo da história, o trabalho se volta a analisar, com base na teoria dos sistemas de Niklas Luhmann, como é possível que essas disciplinas mantenham sua autonomia, a despeito de sua constante e inexorável relação na seara concorrencial. Em seguida, o trabalho busca explorar tanto os benefícios, quanto os limites dessa relação. Nesse sentido, ele apresenta como a interdisciplinaridade, ao mesmo tempo em que pode servir ao mútuo aprendizado e mesmo ao fortalecimento do direito e da teoria econômica, também tem certas limitações que devem ser respeitadas, com vistas a garantir que esses campos do saber conservem sua autonomia e que sua relação permaneça profícua. Com base nisso, a segunda parte do trabalho se dedica a analisar a jurisprudência do Cade no tema já apresentado. Aqui, importa ressaltar, não pretende testar a validade das teorias econômicas ou jurídicas utilizadas pela autoridade, mas refletir sobre o peso que lhes é conferido e a maneira como elas se relacionam. Ao contrapor os pressupostos teóricos à análise jurisprudencial, verifica-se, finalmente, que, de fato, nas decisões da autoridade sobre tabelas médicas, argumentos de cunho econômico têm se sobreposto ao raciocínio jurídico, ou mesmo esvaziado esses últimos. Em face disso e da função de proteção de direitos desempenhada pelo sistema jurídico, ressalta-se a necessidade de se atentar para as questões jurídicas na aplicação do direito concorrencial.

Palavras-chave: Controle antitruste. Direito da concorrência. Teoria econômica. Cade. Tabelas Médicas. 


\begin{abstract}
The purpose of this work is to analyze the relationship between Law and economic theory in the enforcement of Brazilian Competition Law. For this purpose, this work uses case law of the Administrative Council for Economic Defense (CADE) on suggestive or compulsory price fixing of medical fees, more commonly referred to as medical pricing lists. The analysis of this case law is preceded by a theoretical framework, which explains a brief historical retrospective of antitrust control, since its origin, taking the Sherman Act as a milestone. After presenting how the role of Law and economic theory varied throughout history in antitrust control, the work focuses its analysis, based on Niklas Luhmann's Systems Theory, on how those disciplines maintain their autonomy, despite their constant and inexorable relation in the competition field. Following that, the work seeks to explore not only the benefits, but also the limitations, of this relationship. In this sense, the work presents how an interdisciplinary approach can simultaneously promote mutual learning and even the strengthening of law and the economic theory, but also has limitations that must be considered, in order to guarantee that these fields of knowledge conserve their autonomy and that their relationship remains fruitful. On that basis, the second part of the work is dedicated to analyzing CADE case law on the presented subject. It is important to stress that the work does not intend to test the validity of economic or legal theories used by CADE, but rather to reflect on the weight that each is granted and the way they relate among themselves. By applying the theoretical assumptions to the case law, the predominance of economic arguments over legal reasoning, even undermining it to some extent, becomes evident. In view of that, and of the role played by the legal system in protecting rights, the work highlights the need to pay greater attention to legal matters when applying Competition Law.
\end{abstract}

Keywords: Antitrust control. Competition Law. Economic theory. CADE. Medical pricing list. 
FOLHA DE APROVAÇÃO

\section{LUIZA KHARMANDAYAN}

\section{A Relação entre o Direito e a Teoria Econômica na Jurisprudência do Cade sobre} Tabelas Médicas

Dissertação apresentada como requisito parcial à obtenção do grau de Mestre, no Programa de Pós-Graduação da Faculdade de Direito da Universidade de Brasília, linha de pesquisa "Globalização, Transformações do Direito e Ordem Econômica".

em 09 de dezembro de 2015.

\section{BANCA EXAMINADORA}

Prof. Dra. Ana Frazão

(Orientadora - Presidente)

Prof. Dr. Marcelo Neves

(Membro)

Prof. Dr. Luiz Esteves

(Membro)

Prof. Dr. Pablo Holmes

(Suplente) 


\section{Agradecimentos}

A elaboração do presente trabalho se revelou, por motivos diversos, bastante mais complexa do que o inicialmente previsto. A boa surpresa disso foi descobrir o apoio de tantas pessoas e se maravilhar com sua capacidade de oferecer ajuda das mais variadas formas. Certamente não será possível contemplar, aqui, todos que de alguma maneira contribuíram para que essa dissertação fosse concluída. No entanto, há que se registrar o auxílio daqueles que estiveram mais presentes ao longo desse processo e fizeram dele um grande aprendizado.

Em primeiro lugar, agradeço sincera e imensamente à minha orientadora, a Prof. Dra. Ana Frazão. Mais do que simplesmente me apontar os possíveis rumos em momentos de descaminho e confusão, ela fez isso com extrema paciência, empatia e generosidade.

Agradeço também ao Prof. Dr. Marcelo Neves pela disponibilidade em discutir sobre argumentos e teorias tão fundamentais para a elaboração desse trabalho. Enxergar a lógica desse último através de nossas conversas foi um grande motivo para perseverar em sua redação.

Aos meus queridos amigos devo enorme gratidão por tornarem esse desafio mais fácil. Particularmente, agradeço a Ana Carolina Carvalho, Julia Mendes, Mariana Morgado e Talita Miotto por fazerem as vezes de família e me acompanharem em todas as fases, detalhes, percalços e conquistas desse processo. Pelo inabalável apoio à distância e pacientes conversas agradeço a Ana Carolina Rodrigues, Andrea Piazza, Evelyn Doering, Maria de Fátima C. Pinto, e Raquel Trabazzo. A Carolina Saboia, Fabio Sgueri, Francisco Schertel, João Amurim, Rodrigo Belon e Victor Rufino sou grata pelo constante encorajamento e por me lembrarem que a redação de uma tese de mestrado é, na verdade, algo mais simples do que aquilo que eu muitas vezes quis fazer crer. Agradeço a Fabio de Sousa, Max Villela e Luiza Jacobsen por fazerem da rotina algo tão divertido e me auxiliarem a resolver alguns dos desafios com os quais me deparei ao produzir o presente trabalho. A Vinicius Marques de Carvalho sou especialmente grata por compartilhar comigo suas ideias e transformar o dia-a-dia num contínuo aprendizado. A Felipe Daud agradeço pelo grande carinho e parceria que demonstrou nesse e em outros momentos.

Agradeço, por fim, à minha família por todo amparo ao longo desse processo. Às minhas irmãs, Vânia e Silvia, sou grata pelo companheirismo mais do que fraternal e por 
construírem comigo o caminho para perseguir esse e tantos outros planos. Aos meus pais devo imensa gratidão por me ensinarem - minha mãe, Lucia, com seu profundo pragmatismo, e meu pai, Paulo, com seu infinito acolhimento - a enfrentar os desafios que a vida invariavelmente nos coloca. Sem essas referências, esse trabalho não passaria de uma ideia sem destino. 
"The Chicago School offers simplicity, elegance and often relatively easy answers to antitrust questions. The alternatives are almost always messier, more expansive, and less determinate. But policy has to reflect the world we live in, and the world is a messy place."

(H. Hovenkamp)

Para meus pais, meu lar em qualquer lugar. 


\section{Sumário}

1. A relação entre o direito concorrencial e a teoria econômica..................................... 13

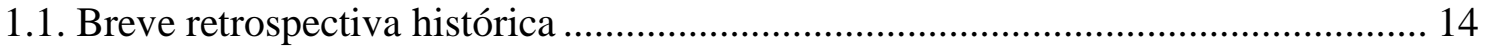

1.1.1. Os objetivos e aplicação do Sherman Act em sua gênese e em seus anos iniciais 14

1.1.2. Interação das normas concorrenciais com diferentes teorias econômicas............ 21

1.1.3. Breve retrospectiva histórica: algumas conclusões ............................................. 29

1.2. Como o direito se relaciona com a teoria econômica no controle antitruste: uma análise a partir da teoria dos sistemas de Niklas Luhmann .......................................... 30

1.2.1. Noções gerais acerca da Teoria dos Sistemas ................................................... 32

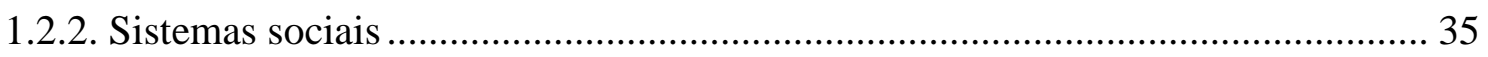

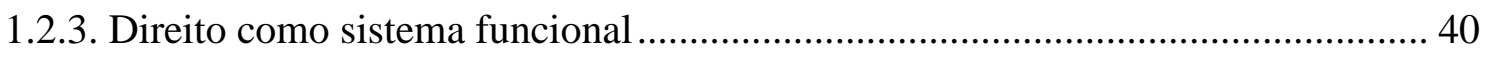

1.2.4. Relação entre o direito e a teoria econômica no controle antitruste sob a ótica da teoria dos sistemas: algumas conclusões .................................................................. 42

1.3. Benefícios da relação entre o direito e teoria econômica no controle antitruste .... 43

1.3.1. As irritações promovidas por acoplamentos estruturais como meios de

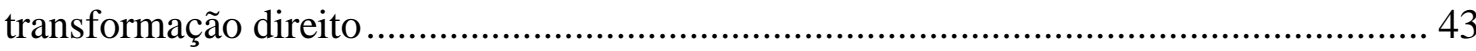

1.3.2. A interação entre o direito e outras disciplinas como forma de combater o conceitualismo

1.3.3. Benefícios da relação entre o direito e teoria econômica no controle antitruste:

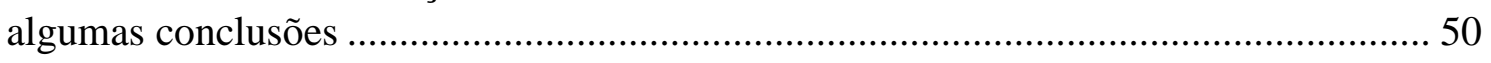

1.4. Limites da relação entre o direito e teoria econômica no controle antitruste .......... 52

1.4.1. As limitações da teoria econômica .................................................................. 52

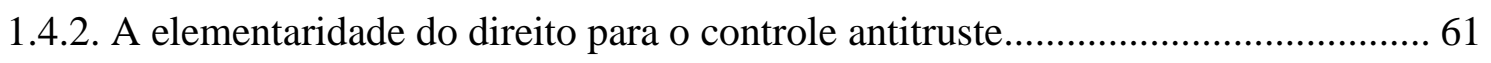

1.4.3. Limites da relação entre o direito e teoria econômica no controle antitruste:

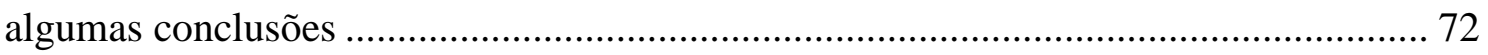

2. Mapeamento e análise da jurisprudência do Cade sobre tabelas médicas................... 74

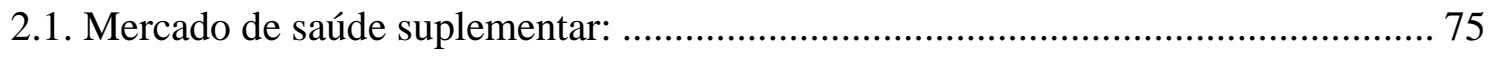

2.1.1. Breve histórico da saúde complementar no Brasil ............................................ 75

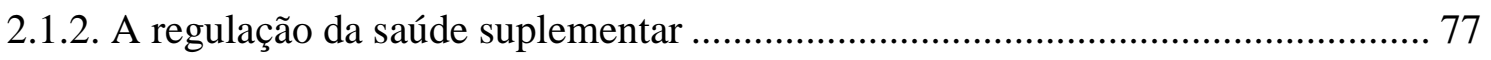

2.1.2.1. Organização da saúde suplementar no Brasil ...................................................... 78

2.1.2.2. Características da saúde suplementar e o impacto da regulamentação no setor 80

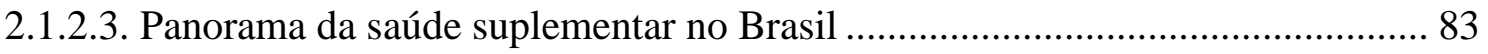

2.1.3. Mercado de saúde suplementar: algumas conclusões.......................................... 86

2.2. Jurisprudência do Cade acerca de tabelas médicas ................................................ 88

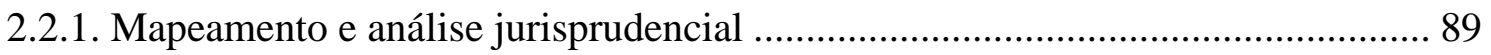

2.2.2. Jurisprudência do Cade acerca de tabelas médicas: algumas conclusões ........... 110 
Conclusão

112

Referências Bibliográficas. 


\section{Introdução}

Apesar de a relação entre o direito e a teoria econômica no controle antitruste ser histórica, não é raro que ela figure como objeto de debates entre os especialistas na matéria. Questões sobre como deve se dar essa relação, quais os seus limites e por que o equilíbrio entre essas duas disciplinas deve ser buscado são apenas alguns exemplos de pontos que alimentam uma discussão repleta de controvérsias. Se, por um lado, a força das ponderações econômicas - dentre as quais se destaca a análise de eficiências - não extinguiu argumentos e valores de outros tipos do estudo e implementação da defesa da concorrência, por outro, há que se atentar para o alerta de alguns autores de que, atualmente, os processos de decisão das autoridades responsáveis pela aplicação do direito concorrencial têm permanecido fechados a argumentos jurídicos substantivos ${ }^{1}$.

O presente trabalho tem por objetivo adentrar esse debate por uma via empírica, analisando as decisões do Conselho Administrativo de Defesa Econômica - Cade a respeito de uma conduta que há décadas tem servido de base para a abertura de um enorme volume de casos na autoridade: tabelamento sugestivo ou impositivo de preços de honorários médicos, mais comumente referido como tabelas médicas. Antes, porém, de embarcar na análise da jurisprudência do Cade na matéria, o trabalho apresenta os pressupostos teóricos que servem de substrato para referido escrutínio. Nesse sentido, o trabalho está divido em duas partes, além da presente introdução e da conclusão.

A primeira parte discorre sobre a relação entre o direito e a teoria econômica no controle antitruste. Para tanto, ela começa por fazer um breve apanhado histórico do controle antitruste, buscando demonstrar que, embora a teoria econômica integre o controle antitruste desde sua origem, seu papel em tal controle, ao longo do tempo, tem sido bastante variado. A política antitruste, afinal, não é algo estanque e, da mesma forma como a teoria econômica interfere sobre a percepção de qual é o objetivo da política concorrencial, também a histórica discussão sobre os objetivos dessa política interfere no papel que os aparatos econômicos nela desempenham.

Uma vez explorado o aspecto histórico da relação entre o direito e a teoria econômica na seara antitruste, o trabalho se volta à compreensão dessa relação a partir de outras perspectivas. Nesse ponto, ele faz uso da Teoria dos Sistemas de Niklas Luhmann, a qual permite compreender o controle antitruste como a acoplamento estrutural entre

\footnotetext{
${ }^{1}$ Vide, nesse sentido, Frazão, 2014 e Schuartz, 2008.
} 
dois sistemas distintos: o direito concorrencial e a teoria econômica. Isso, por sua vez, permite entender como o direito concorrencial, enquanto disciplina autônoma, tem a possibilidade de manter uma abertura cognitiva para economia sem perder sua identidade jurídica.

A importância dessa abertura, por seu turno, não é apenas explicada pela própria teoria de Luhmann. Ao discorrer sobre o pensamento e ensino jurídico no Brasil, Marcus Faro de Castro deixa clara a utilidade do diálogo do direito com outras disciplinas. Desse modo, a interdisciplinaridade entre o direito concorrencial e a teoria econômica, como forma de combater uma abordagem conceitualista do direito, será também explorada quando analisados os benefícios da relação entre as duas disciplinas em questão.

Feitas as considerações sobre a intrínseca e histórica relação entre o direito e a teoria econômica no âmbito antitruste e abordadas a importância e - até mesmo - as vantagens dessa relação, o trabalho se debruça então sobre seus limites. Aqui recorre-se não só à vasta literatura sobre os limites das teorias econômicas para explicar a realidade, mas também, e mais uma vez, à teoria de Luhmann para explicar a importância da diferenciação entre os sistemas. Em linha com essa teoria, são apresentados outros argumentos que sustentam a necessidade de se atentar para as questões jurídicas no controle antitruste, não permitindo que argumentos econômicos substituam os critérios fornecidos pelo próprio direito concorrencial ou pelas normas constitucionais que o informam.

Com base nesses pressupostos teóricos, a segunda parte do trabalho se propõe a analisar a jurisprudência do Cade sobre tabelas médicas. A despeito da variedade de critérios empregados para aferir a ilicitude dessa conduta colusiva, a jurisprudência da autoridade brasileira é bastante robusta no sentido de condená-la. A partir do mapeamento e da sistematização das decisões do Cade, o presente trabalho visa compreender o teor dos argumentos utilizados pela autoridade para pautar suas decisões, conferindo especial atenção à interação entre as normas que disciplinam a defesa da concorrência e a teoria econômica. A hipótese aqui aventada é que, no que diz respeito à conduta de fixação de preço de serviços médicos via tabelamento, os argumentos econômicos tenham sido deixados de ser instrumentos do direito concorrencial, para se tornarem, frequentemente, o único critério decisório. 
Cabe ressaltar que o objetivo do trabalho não consiste em analisar a mérito dos argumentos econômicos aventados nas decisões, mas sim a maneira como são empregados. Assim, apesar de explicar brevemente o mercado de saúde suplementar no Brasil (a maneira como ele está organizado, a regulação que sobre ele incide, etc.), de modo a contextualizar a discussão em torno do emprego de tabelas médicas, o trabalho não pretende testar a validade das teorias econômicas utilizadas pelo Cade em sua jurisprudência, mas refletir sobre o peso que lhes é conferido e a maneira como elas se relacionam com o direito.

Finalmente, o trabalho apresenta uma conclusão que busca sintetizar a contraposição entre os pressupostos teóricos apresentados na primeira parte, e o mapeamento da jurisprudência do Cade sobre tabelas médicas, apresentado na sequência. $\mathrm{Na}$ conclusão, mais do que esclarecer como a autoridade vem empregando a teoria econômica nas decisões emitidas nos casos em tela, procura-se refletir sobre as consequências dessa abordagem. 


\section{A relação entre o direito concorrencial e a teoria econômica}

A relação entre o direito e a teoria econômica jaz na raiz da defesa da concorrência. Apesar de comum, é equivocada a associação do nascimento da influência da teoria econômica sobre o controle antitruste à ascensão da Escola Neoclássica de Chicago, que teve lugar nas últimas décadas do século XX. De fato, a Escola de Chicago representa um marco relevante na aplicação do direito concorrencial. A partir de seus novos referenciais teóricos, o controle antitruste ganhou outros contornos. No entanto, conforme nota Hovenkamp, essa escola não deve ser percebida como a "descoberta" da teoria econômica pelo antitruste, mas, simplesmente, como uma mudança no modelo econômico prevalecente (2005).

A história evidencia que a teoria econômica tem marcado presença na defesa da concorrência desde sua origem e ao longo de diferentes fases, com isso indicando que o papel da economia não é incidental, mas inerente ao controle antitruste. Afinal, a própria noção de restrição à concorrência exige que se proceda à alguma espécie de análise econômica para determinar se certo comportamento pode gerar efeitos anticompetitivos (WHISH, 2005). Por outro lado, conforme mencionado, a história também revela que o papel da teoria econômica no controle antitruste é dinâmico e tanto influencia quanto é influenciado pela discussão sobre os objetivos dessa política.

É com vistas a compreender essa relação que a presente parte deste trabalho se dedica a explorar, primeiramente, os termos da interação entre o direito e a teoria econômica, no controle antitruste, em diferentes momentos, através de uma breve retrospectiva histórica. Aqui, o presente trabalho toma como referência uma das primeiras - e ainda uma das principais - normas concorrências criadas: o Sherman Act. Os objetivos dessa norma em sua gênese, bem como sua aplicação em seus anos iniciais, ilustram como os objetivos por trás da política antitruste e, consequentemente, o papel da teoria econômica nessa política são diversos. Para melhor elucidar o dinamismo dessa relação, a retrospectiva histórica também apresenta como diferentes teorias econômicas informaram a compreensão e aplicação das normas concorrenciais.

Em seguida, com vistas a compreender como o direito e a teoria econômica podem, no controle antitruste, manter uma relação profícua e, ainda assim, permanecerem autônomos, o trabalho recorre à teoria dos sistemas, de Niklas Luhmann. Os prováveis benefícios provenientes dessa relação são igualmente ilustrados pela teoria de Marcus 
Faro de Castro, segundo a qual, a interdisciplinaridade entre o direito (e aqui não há por que se excluir o direito concorrencial) e outras disciplinas serve para prevenir ou mesmo remediar à redução do direito a formas abstratas desconectadas da realidade.

Por outro lado, explorada a maneira pela qual o direito concorrencial e a teoria econômica se relacionam - tanto histórica, quanto teoricamente -, bem como os benefícios decorrentes dessa relação, a presente parte desse trabalho se encerra com considerações sobre os limites dessa interação. Para tanto, faz-se breve menção às limitações dos próprios modelos econômicos para retratar a realidade e para solucionar problemas, bem como às críticas à pretensa neutralidade política desses modelos. Mas, mais do que isso, busca-se, também, nesse ponto, apresentar razões pelas quais as ponderações propriamente jurídicas não devem ser substituídas por argumentos de teoria econômica, no direito concorrencial.

\subsection{Breve retrospectiva histórica}

\subsubsection{Os objetivos e aplicação do Sherman Act em sua gênese e em seus anos iniciais}

As normas concorrenciais são em grande medida marcadas por uma característica que dificulta a extração de seu significado a partir da simples leitura de seu texto: a vagueza e a maleabilidade da linguagem empregada ${ }^{2}$. Diante dessa característica, tornase particularmente útil atentar-se para os discursos e decisões que circundam sua criação e aplicação (HOVENKAMP, 2005). Em outras palavras, o contexto histórico por trás da criação e aplicação das normas antitruste é especialmente relevante para sua compreensão.

A primeira legislação antitruste do mundo não teve origem nos Estados Unidos, mas no Canadá, em $1889^{3}$. No entanto, o Sherman Act, primeira lei norte-americana a

\footnotetext{
${ }^{2}$ Hovenkamp argumenta nesse sentido ao tratar do Sherman Act (2005, p.49). O mesmo argumento é apontado por Krattenmaker, Lande e Salop, em relação a outras normas concorrenciais norte-americanas, tal como o Clayton-Act (1987, p. 2). Também Richard Whish faz referência a esse fenômeno ao discorrer sobre o Tratado sobre o Funcionamento da União Europeia - TFEU (2005).

${ }^{3}$ Conforme explicam Oliveira e Rodas, "[c]redita-se ao Canadá o prioneirismo no estabelecimento de legislação concorrencial. Ainda sob o domínio inglês, editou, em 1889, um Act for the Prevention and Suppression of Combinations formed in Restraint of Trade, com o objetivo de atacar os problemas de combinações ou conluio para restringir o comércio, para fixar preços ou restringir a produção, que acabou sendo incorporado, três anos após, ao primeiro Código Penal do Canadá” (2013, p. 18).
} 
abordar o controle de condutas anticompetitivas e que ainda hoje serve de fundamento para a realização dessa atividade nos Estados Unidos, certamente se tornou a principal referência para os demais países nessa seara (FRAZÃO, 2014). Por isso, o histórico da aplicação do direito antitruste norte-americano, assim como das diversas teorias a seu respeito denotam bem os diferentes papéis que a teoria econômica pode assumir no direito concorrencial, a depender tanto de seu próprio conteúdo, quanto dos objetivos que se atribui à defesa da concorrência.

O Sherman Act foi aprovado pelo Congresso norte-americano em 1890. Finda a Guerra de Secessão, a economia do país experimentou significativo incremento em virtude da progressiva ocupação do Oeste, da vultosa imigração europeia (OLIVEIRA \& RODAS, 2013) e de uma série de inovações tecnológicas em diversos setores (e.g., metalurgia, químicos e energia). Conforme observa Motta, talvez o evento mais importante à época tenha sido a dramática melhoria no setor de transporte e de comunicação, que permitiu a formação de um amplo e único mercado, conferindo às empresas incentivos para explorar economias de escala e escopo. Isso, somado à formação de mercados de capital mais avançados, novos métodos administrativos e inovações legais, possibilitou a expansão do tamanho das empresas (MOTTA, 2004).

É interessante notar que alguns desses mesmos eventos descritos acima contribuíram para a queda e para instabilidade de preços à época. De fato, os ganhos de escopo e de escala reduziram os custos das empresas. Ao mesmo tempo, a queda dos custos com transporte e comunicação, que havia possibilitado a expansão do mercado em muitos setores, aumentou a concorrência entre as empresas, forçando seus preços para baixo. Essas últimas, porém, não permaneceram indiferentes a esse cenário e responderam às guerras de preços e à instabilidade de mercado com acordos de preço, por meio de cartéis e a formação de trustes ${ }^{4}$ (MOTTA, 2004).

A concentração de poder em mãos de alguns agentes econômicos, propiciada por esses comportamentos, levou, por sua vez, à reação da sociedade pela via legislativa. $\mathrm{O}$

\footnotetext{
${ }^{4}$ Para compreender o funcionamento dos trustes, vale recorrer a explicação de Paulo Furquim em seu voto no Processo Administrativo no 08012.007042/2001-33: “é creditado a John D. Rockfeller, em 1882, a criação do modelo de trustes, em que corporações de uma mesma indústria transferiam o controle de suas propriedades a uma entidade legal separada. Um conselho desta entidade legal - o truste - recebia, então, o controle desses ativos, por delegação dos acionistas de cada corporação. Este tipo de arranjo eliminava a possibilidade de não-cooperação por parte de algumas das empresas participantes, assim como permitia a gestão centralizada da indústria, como uma entidade única, arrefecendo a concorrência e permitindo ações de interesse comum, como a destruição de capacidade ociosa".
} 
Sherman Act surgiu como uma tentativa de coibir os problemas relacionados ao abuso de poder econômico, através de sua disciplina (GABAN \& DOMINGUES, 2012).

Diante desse cenário de grande concentração de capital, parece plausível a narrativa, em algum momento endossada pela Escola de Chicago, de que o intuito de promover a eficiência alocativa ${ }^{5}$, tal como pregado pela economia neoclássica, foi o que guiou a elaboração do Sherman $A c t^{6}$. No entanto, essa ideia é desafiada por contundente argumento de Hovenkamp, segundo o qual sequer seria possível que os idealizadores do Sherman Act tivessem a eficiência de Pareto $^{7}$ em mente ao elaborar essa norma, uma vez que tal teoria nem mesmo havia sido desenvolvida à época de sua aprovação. Tampouco é provável que os conceitos de eficiência alocativa e perda de peso morto decorrente do monopólio fossem conhecidos pelos legisladores do Sherman Act, haja vista que eles foram desenvolvidos, em grande parte, em obra apenas publicada $1890^{8}$.

Por outro lado, não parece irrazoável argumentar que, ainda que o intuito não fosse promover a eficiência alocativa nos moldes da Escola Neoclássica de Chicago, o Sherman Act tinha como norte principal a preocupação de que a colusão entre concorrentes conduzisse ao aumento artificial de preços e prejudicasse o consumidor. Outros elementos apontam, porém, para um cenário mais complexo, no qual elementos diversos também devem ser considerados.

Talvez mais decisivos, para a edição do Sherman Act, do que os preços mais elevados para os consumidores ${ }^{9}$, tenham sido os efeitos que os trustes e cartéis tiveram

\footnotetext{
${ }^{5}$ Whish, ao explicar eficiência alocativa, esclarece que na concorrência perfeita, os recursos econômicos são alocados entre diferentes bens e serviços de maneira que não é possível deixar ninguém melhor, sem deixar alguém pior; o excedente do consumidor - o ganho líquido do consumidor quando adquire um produto - é o maior possível. (2005, p. 4)

${ }^{6}$ Ver, nesse sentido, Bork, Robert H. "Legislative Intent and the Policy of the Sherman Act", 9 Journal of Law \& Economics. 1966.

${ }^{7}$ A teorização sobre a eficiência de Pareto é atribuída ao Manual d' Economie Politique, de Vilfredo Pareto, datado de 1909. Segundo Stiglitz, "quando ninguém pode melhorar sua situação sem piorar a de outrem, a alocação dos recursos é chamada de eficiência de Pareto, por causa do grande economista e sociólogo italiano Vilfredo Pareto (1848-1923). (...) Para que a economia seja eficiente no sentido de Pareto ela deve cumprir as condições de eficiência de trocas, de eficiência da produção e de eficiência do produto" (Stiglitz, 2003, pp. 171-172).

${ }^{8}$ A obra em questão trata-se de Principles of Economics, do economista Alfred Marshall, da Universidade de Cambridge.

${ }^{9}$ Vale notar que a elevação de preços à época parece ser algo controverso. Por um lado, Massimo Motta argumenta que "final consumers were hurt by higher prices, and so were producers, such as farmers and small industrial firms, which used products of cartelised sectors as an input" (2004, p. 3). Por outro, Hovenkamp observa que "the decade before 1890 was generally a period of declining rather than increasing prices. Indeed, by some measures the rate and the extensiveness of price declines was unprecedented - a general 7\% decline in the consumer price index, as output expanded dramatically. Although much of the wrath of the Sherman Act's framers was directed at two targets, the Standard Oil
} 
sobre alguns setores produtivos, como agricultores e pequenos empresários. Estes se queixavam de sofrer com insumos com preços mais elevados e produtos finais com preços mais competitivos que os seus. Ademais, protestavam contra práticas de mercado desleais adotadas por seus concorrentes de grande porte, os quais - alegavam - tentavam excluílos do mercado (MOTTA, 2004). Tais grupos, além de prejudicados pela maior eficiência das grandes empresas, eram bem organizados e tinham um longo e bem-sucedido histórico de fazer suas demandas chegar aos legisladores (HOVENKAMP, 2005).

Adicionalmente, deve ser considerado o fato de que, à medida que crescia o poder das grandes empresas, também crescia o ressentimento da população (FREDERICK, 2002, p. 22), a qual associava uma série de problemas à concentração de poder econômico, tais como ameaça à liberdade, corrupção, fraude, dentre outros ${ }^{10}$. A ideia de que os trustes eram imorais e de que possibilitavam a fortuna de poucos às custas de agricultores, trabalhadores e consumidores era alimentada, inclusive, por uma intensa campanha publicitária contra essas formas de organização (DILORENZO, 1985).

Esses fatos evidenciam que o Sherman Act, em sua gênese, era um reflexo de preocupações da sociedade norte-americana com outras questões que não apenas - ou sequer majoritariamente - eficiência econômica. Nos Estados Unidos do século XIX tinha força a ideia de que o gigantismo de agentes privados deveria ser temido, em função do poder político que ele poderia engendrar. Nesse sentido, é razoável a conclusão de que "a retórica do século XIX norte-americana em relação a monopólios se preocupava com a grandeza per se das empresas, tanto quanto se preocupava com preços monopolísticos" (HOVENKAMP, 2005, p. 52, tradução livre) ${ }^{11}$.

Company and the sugar trust, the price of the products produced by those firms had dropped precipitously during the preceding decade. From the 1880 through 1890 the price of refined petroleum had fallen by $61 \%$ and output had increased four-fold. Refined sugar prices fell more than eighteen percent between 1880 and 1889. The iron and steel industry, another target of the Sherman Act's proponents, had witnessed declines of about twenty percent. [Those] points (...) make it unlikely that Congress was really very concerned about consumers' having to pay high prices." (Hovenkamp, 2005, p. 51)

${ }^{10}$ Segundo DiLorenzo, "Trusts, it was said, threatened liberty, because they corrupted civil servants and bribed legislators; they enjoyed privileges such as protection by tariffs; they drove out competitors by lowering prices, victimized consumers by raising prices, defrauded investors by watering stocks, and somehow or other abused everyone. The kind of remedy that the public desired was also clear enough: it wanted a law to destroy the power of trusts" (DiLorenzo,1985, p.76-77).

${ }^{11}$ Nos termos de Hovenkamp: "perhaps more consistent. with nineteenth century American ideology generally, is that the antitrust laws were passed out of a pervasive fear of private 'bigness' and the political power that it engendered. The nineteenth century American rhetoric on monopoly is concerned at least as much with bigness per se as it is with monopoly prices. (...) If one looks at the ideology of nineteenth century Americans, rather than the interest groups that may have contributed to the Sherman Act's formation, the anti-bigness rationale seems to be very important". 
Dito de outro modo, são robustos os indícios de que os motivos a embasar a elaboração de uma das principais referências legislativas do direito concorrencial no mundo vão significativamente além de uma noção de eficiência econômica identificada com preços mais baixos. Baker endossa explicitamente essa narrativa, ao explicar que

a geração fundadora do antitruste enxergava no Sherman Act uma forma de proteger, contra interferências artificiais, os direitos naturais à liberdade econômica, à propriedade e a um processo competitivo de livre comércio. Dessa forma asseguraria, concomitantemente, o máximo de liberdade em empreender, eficiência econômica, prosperidade nacional, justiça, harmonia social e liberdade individual. ${ }^{12}$ (2002, p. 4)

Na realidade, é curioso observar que, a despeito da habitual associação do Sherman Act à uma busca por maior eficiência econômica, a maioria dos economistas à época se opunha à sua aprovação e aplicação, uma vez que considerava que a norma poderia comprometer a capacidade de grandes empresas oferecerem preços menores devido aos ganhos de escopo e escala (KOVACIC \& SHAPIRO, 2000). A teoria econômica clássica, a qual detinha considerável força então, sustentava, afinal, que a concentração de poder econômico propiciava a expansão da indústria e o incremento da produção (FORGIONI, 1998). Nota-se, portanto, certo descasamento entre a teoria econômica dominante no período em que o Sherman Act foi aprovado e a ideologia que lhe subjazia.

De fato, com a teoria econômica neoclássica, mais comumente identificada com o desenvolvimento das curvas de custo marginal e lucro marginal, a análise econômica se tornou mais sútil, ao passo que os economistas se tornaram cada vez mais conscientes das falhas de mercado que podem permitir uma série de condutas anticompetitivas. Ocorre que a ascensão dessa teoria só veio a ter lugar nas décadas de 1870 e 1880, de modo que a revolução por ela promovida coincidiu exatamente com o momento de aprovação do Sherman Act.

Como consequência, entre 1890 e 1920 a teoria econômica foi palco de diversas disputas entre os clássicos e os emergentes neoclássicos e observou-se uma grande variedade de pontos de vista sobre a lesividade de diversas condutas (HOVENKAMP, 2005). No entanto, a teoria clássica ainda possuía muita força no momento da aprovação

\footnotetext{
${ }^{12}$ [A]ntitrust's founding generation understood the Sherman Act as a way to protect natural rights to economic liberty, security of property and the process of competitive, free exchange from artificial interference. Doing so would tend at once to secure a maximum of individual business opportunity, economic efficiency, national prosperity, justice, social harmony and personal freedom.
} 
da referida norma, conforme ilustram as discussões levadas a cabo por economistas à época, descritas por Kovacic e Shapiro:

Além de atribuir às economias de escala e escopo um grande aumento de ganhos, os economistas do período [1890-1914] debatiam ativamente se a concorrência desenfreada punha em risco indústrias com altos custos fixos e baixos custos marginais. Outros, antecipando Ramsey, Pigou e Hottelling, reconheciam que a discriminação de preços poderia permitir que as empresas recuperassem os custos fixos. A clássica obra de Schumpeter, História da Análise Econômica (1954), reflete o foco da época. Ao discutir o período de 1870 a 1914, Schumpeter não se refere a "organizações industriais", mas sim a "Ferrovias, Utilidades Públicas, Trustes e Cartéis"13. (2000, p. 44, tradução livre)

Não há que se entender, porém, que descasamento entre a teoria econômica dominante no período e a ideologia subjacente à elaboração do Sherman Act sirva para demonstrar a independência do controle antitruste em relação à disciplina econômica e às ferramentas que ela oferece.

À medida que as cortes passaram a dar forma aos vagos termos empregados no texto legal da norma em questão, a relevância de conceitos e argumentos oriundos da economia passou a despontar ${ }^{14}$. Ainda que em alguns casos iniciais as cortes tenham interpretado de maneira bastante literal e restritiva a previsão de que "é ilícito qualquer contrato que restrinja o comércio", mesmo neles houve o reconhecimento de que a proibição a todos os acordos que cerceassem a liberdade comercial poderia impedir formas benéficas de cooperação. A tarefa analítica inicial de definir as nuances dessas previsões legais - como, por exemplo, quais comportamentos que, conjugados com poder monopólio, constituíam monopolização ilegal - não podia prescindir de considerações de cunho econômico (KOVACIC \& SHAPIRO, 2000).

\footnotetext{
${ }^{13}$ Beyond envisioning large gains from economies of scale and scope, economists at this time actively debated whether unbridled competition endangered industries with high fixed costs and low marginal costs, like railroads and utilities. Some argued that government ownership was needed to enable such industries to recover fixed costs. Others, anticipating Ramsey, Pigou, and Hotelling, recognized that price discrimination could enable firms to recover fixed costs. Schumpeter's classic History of Economic Analysis (1954) reflects the focus of the day. In discussing the 1870-1914 period, Schumpeter refers not to industrial organization" but rather to "Railroads, Public Utilities, Trusts, and Cartels."

${ }^{14}$ Segundo Kovacic e Shapiro: By enlisting the courts to elaborate the Sherman Act's broad commands, Congress also gave economists a singular opportunity to shape competition policy. Because the statute's vital terms directly implicated economic concepts, their interpretation inevitably would invite contributions from economists. What emerged is a convergence of economics and law without parallel in public oversight of business. As economic learning changed, the contours of antitrust doctrine and enforcement policy eventually would shift, as well. (2000, p. 43).
} 
Também deve ser ressaltado que, embora tenha havido um descasamento entre a teoria econômica clássica e a ideologia subjacente à elaboração do Sherman Act, essa relação não se manteve estática. De fato, na primeira década de vigência dessa norma, sua aplicação não foi muito estrita (MOTTA, 2004). Conforme explica Hovenkamp, a maior tolerância do direito antitruste com colusões e com grande parte das restrições verticais era reflexo da percepção extremamente robusta que a economia política clássica tinha de mercado, do papel desempenhado pela concorrência potencial e da capacidade de ausências de barreiras à entrada funcionarem como disciplinadores de qualquer tentativa de aumentar preços acima do nível competitivo (1989).

Na realidade, assim como o argumento de que outros motivos, que não a eficiência econômica, embasaram e impulsionaram a elaboração do Sherman Act, o descasamento entre esses motivos e a teoria econômica clássica (dominante à época da aprovação dessa lei) se presta a ilustrar a complexidade da relação entre objetivos do controle antitruste, as teorias econômicas ou de outros tipos que o embasam, e a sua aplicação.

A gênese e os primórdios do Sherman Act são ilustrativos de como é dinâmica a interação entre esses elementos: se o intuito do Sherman Act divergia do referencial teórico da escola econômica dominante no período, a aplicação inicial da lei logo demonstrou que a relação entre esses elementos era suscetível a modificações. Afinal, a ideologia e motivações por trás da elaboração do Sherman Act não impediram que ele fosse utilizado, para o horror de alguns de seus apoiadores iniciais, como forma de coibir ações de sindicatos de trabalhadores e de cooperativas agropecuárias, nos primeiros anos de sua vigência (FREDERICK, 2002). Tampouco impediram que houvesse, entre 1895 e 1905, a maior onda de concentrações de empresas na história norte-americana, denotando a ironia do fato de que uma norma, que pretendia fazer frente à concentração econômica e ao gigantismo de agentes econômicos, engendrou, precisamente, o efeito oposto, haja vista que as empresas tiveram de fazer por meio de fusões o que não podiam fazer pela via contratual (HOVENKAMP, 2005).

Mas não é apenas a fase inicial do Sherman Act que ilustra a complexidade da interação entre os objetivos pretendidos com uma norma, o arcabouço teórico que a ampara e sua aplicação. As diferentes interpretações já dadas a essa norma, ao longo de sua história, são também elucidativas de como a relação entre esses elementos é dinâmica. Stucke, ao discorrer sobre as preocupações que a Suprema Corte do Estados Unidos já atribuiu ao Congresso do país ao elaborar o Sherman Act, explica: 
Em diferentes casos, ao longo dos anos, a Corte afirmou que o Congresso buscava: prevenir a concentração de mercado através de aquisições; perpetuar e preservar uma organização industrial em pequenas unidades (...); promover o bem-estar do consumidor, eficiência alocativa e preços competitivos; proteger a população de falhas de mercado; proteger a liberdade econômica e a liberdade de cada negócio de competir (...); condenar práticas que excluem completamente concorrentes não apenas dos negócios em que eles já atuam, mas também de oportunidades de construir um negócio onde grandes e poderosos agentes operam (...); garantir a igualdade de oportunidade e proteger as pessoas contra males comumente presentes na destruição da concorrência (...); ser uma lei que compreenda a liberdade econômica voltada à preservação da concorrência livre como uma regra de comércio $^{15}{ }^{16}$. (2012, pp. 560-562, tradução livre)

A elaboração do Sherman Act, bem como as primeiras fases de sua aplicação demonstram, portanto, que a defesa da concorrência não é sinônimo de uma disciplina estritamente informada pela teoria econômica - quanto menos, como se verá a seguir, pela teoria econômica neoclássica tão somente -, exclusivamente voltada a garantir preços mais baixos aos consumidores e absolutamente indiferente a ponderações de outras espécies. O papel por ela desempenhado pode ser dos mais diversos e certamente variará ao longo do tempo, a depender não somente da teoria econômica que lhe serve de substrato, como também da forma como se interpretam as incumbências que lhe foram atribuídas.

\subsubsection{Interação das normas concorrenciais com diferentes teorias econômicas}

A história da elaboração do Sherman Act e de sua aplicação em seus primeiros anos demonstra que outras considerações e objetivos, além dos atrelados a teorias

\footnotetext{
${ }^{15}$ In verbis: In different cases over the years, the Court has stated that Congress sought to: prevent the concentration of markets through acquisitions, and "perpetuate and preserve, for its own sake and in spite of possible cost, an organization of industry in small units which can effectively compete with each other"; protect firms' "right of freedom to trade"; promote consumer welfare, allocative efficiency, and price competition; "protect the public from the failure of the market"; preserve economic freedom and the freedom for each business "to compete - to assert with vigor, imagination, devotion, and ingenuity whatever economic muscle it can muster"; condemn practices that "completely shut out competitors, not only from trade in which they are already engaged, but from the opportunities to build up trade in any community where these great and powerful combinations are operating under this system and practice"; "secure equality of opportunity and to protect the public against evils commonly incident to destruction of competition through monopolies and combinations in restraint of trade"; "be a comprehensive charter of economic liberty aimed at preserving free and unfettered competition as the rule of trade".

${ }^{16}$ Hovenkamp narra o mesmo fenômeno. De acordo com ele, a linguagem ambígua das normas antitruste produziu disputas acadêmica consideráveis sobre a intenção do Congresso. Para o autor, isso é particularmente verdade em relação ao Sherman Act, cujo texto expansivo tem sido desde sempre a força na política antitruste norte-americana. (Hovenkamp, 2005, p. 49)
} 
econômicas, também podem compor o controle antitruste. Mas mais do que isso, referida história evidencia como a própria identificação da defesa da concorrência à eficiência econômica, nos moldes da Escola de Chicago, não é uma verdade necessária, mas sim uma abordagem bastante obtusa.

A Escola Neoclássica de Chicago, com seus ideais de eficiência alocativa e produtiva é, em verdade, relativamente recente. Antes que ela atingisse seu auge, na década de 1980, importantes debates entre teorias econômicas e sua aplicação à defesa da concorrência tiveram lugar. A relação entre ambos variou (e varia) não apenas em função do conteúdo da teoria econômica dominante em uma ou outra situação, mas também do peso que se lhe é atribuído.

Em suas duas primeiras décadas, o Sherman Act não representou uma reviravolta no mundo antitruste (KOVACIC \& SHAPIRO, 2000). Conforme observado, o pensamento econômico clássico, embora não tenha obtido sucesso em sua oposição à aprovação da norma, parece ter influenciado uma postura relativamente branda em sua aplicação inicial.

No entanto, também nos moldes do exposto, a teoria econômica atravessou, entre 1890 e 1920, uma fase irrequieta em função dos embates entre os clássicos e os neoclássicos. Ao fim do primeiro quartel do século $\mathrm{XX}$, importantes acontecimentos marcaram a defesa da concorrência, sinalizando que a mudança para a mentalidade pósclássica estava a ocorrer gradualmente (HOVENKAMP, 2005).

Em primeiro lugar, destaca-se a decisão da Suprema Corte no caso Standard Oil v. United States, a qual tratou da questão de abuso de posição dominante, utilizou o percentual de mercado como indicador da existência de poder de mercado e estabeleceu a regra da razão como método de análise para algumas condutas. Tal decisão, paradigmática em diversos aspectos, ilustra também a variedade de percepções que então se tinha do controle antitruste. Na medida em que sintetiza perspectivas divergentes (BAKER, 2002), a decisão da corte parece ser indicativa de uma fase de transição, em que conviviam objetivos e teorias econômicas não necessariamente consoantes.

Isso porque, se, por um lado, a determinação de que uma situação de monopólio fosse desconstituída denotava a noção de que algumas formas de concentração de mercado deveriam ser combatidas - em linha com a mentalidade neoclássica -, por outro, a regra da razão era vista por alguns como uma forma de enfraquecer o próprio Sherman 
$A c t^{17}$ - nesse suposto intuito, em linha com a mentalidade clássica. Nesse último caso argumentava-se que, ao deixar claro que restrições não-razoáveis ao comércio eram proibidas por essa lei, a Suprema Corte acabara por flexibilizar a norma, sinalizando que grandes empresas não estavam, meramente por seu tamanho, em conflito com as regras antitruste (BAKER, 2002).

A aprovação do Clayton Act, explicitamente proibindo alguns tipos de acordo e algumas formas de fusão, e a criação da Federal Trade Commission - órgão administrativo encarregado da política antitruste que ampliou as bases para a responsabilização por ilícitos concorrenciais - são dois outros marcos na história antitruste norte-americana que datam do período. Vale notar que ambos consistiam em reações à decisão da Suprema Corte no caso Standard Oil v. United States, uma vez que se pretendiam um arrocho - medidas fortes no sentido de domar as grandes corporações - em face de um suposto afrouxamento promovido pela corte (HOVENKAMP, 2005).

Conforme observam Kovacic e Shapiro, apesar de tais acontecimentos indicarem que a defesa da concorrência nos Estados Unidos estava a ganhar novo vigor, o controle antitruste entrou, entre 1915 e meados da década de 1930, em relativo repouso (2000). Nesse período, as cortes revelaram uma postura bastante moderada em relação a concentrações (HOVENKAMP, 2000) e frequentemente trataram de maneira permissiva comportamentos suspeitos (KOVACIC \& SHAPIRO, 2000).

O contexto histórico do país aqui mais uma vez revela-se importante. A Primeira Grande Guerra modificou a postura do Estado em relação à regulamentação da economia (FORGIONI, 1999). A visão de que a colaboração entre empresas e Estado constitui a melhor forma de organizar a economia, a qual havia orientado a atuação estatal em tempos de guerra, permaneceu a viger em tempos de paz. Com a crise de 1929, o questionamento ao modelo competitivo de organização econômica foi reforçado. Como consequência, a política antitruste se retraiu. Nota-se que tal retração não se deu, porém, a despeito de qualquer modelo econômico, mas com base em um modelo econômico não orientado pelos pressupostos neoclássicos.

\footnotetext{
17 Além de Baker, Hovenkamp também narra a percepção de que a decisão da Suprema Corte no caso Standard Oil v. United States era vista por alguns como um enfraquecimento do Sherman Act: "notwthstanding the convictions in those cases [Standard Oil and American Tobacco], many Progressive Era liberals believed that the rule of reason would greatly weaken the Sherman Act, a position reinforced by rulings such as Henry v. A.B. \& Dick Co. that Tying arragements should be considered reasonable under the Sherman Act”" (2005, p. 57).
} 
Em meados da década de 1930, porém, os modelos econômicos de planificação pelo Estado começaram a perder seu apelo e a defesa da concorrência ressurgiu como um aliado da restauração econômica. A política antitruste se tornou mais agressiva, com o foco em mercados concentrados e na redução do ônus da prova pelo governo. Aumentou o número de condutas consideradas ilícitas com base na regra per se, ao passo que argumentos de eficiência eram amplamente ignorados pelas cortes, sinalizando que uma melhor performance não poderia servir como explicação para a existência de poder de mercado. Ao mesmo tempo, argumentos não relacionados a eficiência, tal como a preservação de pequenas empresas, eram considerados relevantes para a devida aplicação das leis concorrenciais. Essa tendência se estendeu como linha dominante pelas três décadas seguintes (KOVACIC \& SHAPIRO, 2000).

Ainda que alguns teóricos associem a política antitruste dessa época a objetivos populistas $^{18}$, tal política - é necessário enfatizar - não era implementada a despeito da ideologia econômica dominante no período, mas estava em linha com ela.

Referida ideologia econômica conferia um peso significativo a questões estruturais e era bastante hostil ao gigantismo de empresas. A concorrência entre os agentes econômicos era - ao mesmo tempo em que desejável - percebida como uma frágil conjuntura que apenas poderia ser mantida com a supervisão do governo. Nesse contexto, a referência passou a ser um modelo de concorrência viável (workable competition), no qual se reconhece que, ainda que a teoria da concorrência perfeita padeça de limitações, deve-se buscar o melhor arranjo concorrencial que puder ser atingido na prática (WHISH, 2005).

Mais especificamente, esse modelo econômico estruturalista, encabeçado pela Escola de Harvard, parte do pressuposto de que uma estrutura competitiva viável tem um efeito benéfico sobre a conduta e o desempenho dos agentes econômicos, devendo, portanto, ser resguardada pela política antitruste. Em uma indústria concentrada, as empresas estariam à salvo da concorrência pela existência de "barreiras à entrada, consistentes em economias de escala, exigências maiores de capital, know how escasso e diferenciação de produtos" (SALOMÃO, 2003, p. 22). Diante disso, as poucas empresas

\footnotetext{
${ }^{18}$ Ver, nesse sentido, Devlin: from the 1940s through the 1960s, for instance, the global Market place was characterized by relatively weak competition, which surely tempered the need for the U.S. economy to emphasize efficiency. Instead, the U.S. competition law reflected populist goals that included the dispersion of economic power and the protection of commercial liberty (2010, p. 563).
} 
a compor o mercado teriam a possibilidade de eliminar a rivalidade e exercer poder de mercado, prejudicando não apenas seus consumidores, como também as pequenas empresas (BAKER, 2002). A busca por uma estrutura pulverizada de mercado, fomentado pelo paradigma Estrutura-Conduta-Desempenho (E-C-D), refletia, portanto, uma preocupação central dos economistas não com a eficiência, mas sim com a existência de efetiva concorrência (SALOMÃO, 2003) ${ }^{19}$.

Influenciados por essa teoria, tanto o Congresso quanto as cortes demonstraram uma aversão a concentrações, a qual marcou a política antitruste norte-americana até a década de 1970, e cujo ápice se deu nos anos de $1960^{20}$. No entanto, há que se registrar que tal orientação não se calcava estritamente na teoria econômica. Como observa Pitofsky, outras preocupações informavam a abordagem dada à defesa da concorrência, no período:

\begin{abstract}
O Congresso, nas normas antitruste que aprovava - mais claramente quando emendou a seção 7 do Clayton Act, em 1950 -, demonstrava uma preocupação clara de que uma ordem econômica, dominada por algumas poucas corporações gigantes pudesse, em um momento de fragilidade ou tumulto doméstico, facilitar a deposição de instituições democráticas e a instalação de um regime totalitário. Essa preocupação com a existência de um poder econômico e a vontade de dispersá-lo condizem com a preferência governamental geral norte-americana por um sistema de freios e contrapesos e pela distribuição de autoridade com vistas a evitar ações abusivas por parte do Estado ${ }^{21}$. (1979, p. 3, tradução livre, grifos nossos)
\end{abstract}

\footnotetext{
${ }^{19}$ Hovenkamp resume bem o pensamento de Joe S. Bain, um dos mais influentes economistas do período, calcado em três premissas. O primeiro é de que economias de escala não são substanciais na maioria dos mercados e ditam níveis de concentração verdadeiramente anticompetitivos em apenas uma pequena quantidade de mercados. A consequência disso é que diversos mercados contêm grandes empresas e são mais concentrados do que o necessário para atingir a eficiência produtiva ótima. A segunda teoria do autor é que as barreiras à entrada para novas empresas são muito altas e podem ser facilmente manipuladas por empresas com posição dominante. $\mathrm{O}$ terceiro pilar é que a performance não competitiva (preços de monopólio) associada ao oligopólio começam a ocorrer em níveis de concentração relativamente baixos (HOVENKAMP, 2005).

${ }^{20} \mathrm{Na}$ década de 1950, o Clayton Act foi emendado, tornando a política antitruste mais restritiva. Tal modificação converge com a orientação da Suprema Corte, encabeçada por Earl Warren. Num período que se estende até 1969, conhecido por Warren Court Era, adotou-se uma presunção quase absoluta de que concentrações entre concorrentes eram lesivas, considerou-se ilícita a discriminação de preços entre distribuidores, declarou-se a distribuição exclusiva por territórios um ilícito per se, etc (BAKER, 2002). A preocupação dos economistas com oligopólios e concentração de mercado se traduziu também nas políticas do Congresso, as quais evidenciavam uma desconfiança com a expansão de empresas e eram mesmo hostis à eficiência (HOVENKAMP, 2005)

${ }^{21}$ Nos termos do autor: Congress has in its antitrust enactments - most clearly when it amended section 7 of the Clayton Act in 1950 - exhibited a clear concern that an economic order dominated by a few corporate giants could, during a time of domestic stress or disorder, facilitate the overthrow of democratic institutions and the installation of a totalitarian regime. That concern about economic power and the desire that it be dispersed complements the general American governmental preference for a system of checks and balances and distribution of authority to prevent abusive actions by the state.
} 
Apesar de ser comumente associada à uma abordagem estritamente técnica, também a Escola de Chicago - orientação preponderante a partir da década de 1980 - foi influenciada pela conjuntara econômica e política do país - além de tê-la influenciado.

Calixto Salomão Filho situa o nascimento dessa escola nos anos de 1950, com os trabalhos de um economista chamado Aaron Director, cujo trabalho resumiu-se - segundo o autor - à "aplicação, ainda bastante simplificada, da price theory ao direito antitruste, em uma época em que os estudos econômicos sobre a matéria eram assistemáticos e descritivos" (SALOMÃO, 2003, p. 21).

O influxo das teses da Escola de Chicago na defesa da concorrência é, de fato, bastante anterior aos anos 80. No entanto, data das décadas de 1960 e 1970 o trabalho de economistas e juristas, dentre os quais destacam-se R. Bork e Posner, de aplicar a teoria marginalista ao estudo do direito antitruste e traduzir preceitos analíticos em princípios operacionais para que os juízes pudessem prontamente aplicá-los.

É, portanto, nos anos 70 que ocorre um grande embate entre a já mencionada Escola Estruturalista de Harvard e a Escola Neoclássica de Chicago. É também desse período a marca notória dessa última escola de - mais do que rejeitar a regulação abrangente pelo Estado, como já faziam seus predecessores - enfatizar a eficiência como base para a explicação de diversos fenômenos, tais quais, a concentração de mercados, fusões e aquisições e restrições contratuais (KOVACIC \& SHAPIRO, 2000).

A partir das ferramentas microeconômicas oferecidas pela teoria econômica neoclássica dessa escola, a jurisprudência antitruste norte-americana foi profundamente transformada. Os efeitos das concentrações entre empresas, da existência de posição dominante, de restrições verticais e de outras condutas, passaram a ser rigorosamente analisados pela ótica da eficiência alocativa e produtiva ${ }^{22}$. É importante destacar que a Escola de Chicago buscou estabelecer a eficiência como o único objetivo da política de defesa da concorrência (HOVENKAMP, 2005).

Conforme adiantado, apesar do apelo dos aparatos fornecidos pela escola em questão, seria impreciso afirmar que tão somente a teoria econômica explica a substancial mudança de orientação da política antitruste nos Estados Unidos. Afinal, a noção de que

\footnotetext{
${ }^{22}$ Segundo Whish, há eficiência produtiva quando os bens e serviços de uma sociedade são produzidos ao custo mais baixo possível, de modo que o mínimo necessário de riqueza da sociedade é consumido no processo produtivo (2005).
} 
a dispersão artificial de poder econômico pode levar a perdas de eficiências é mesmo anterior a Escola Neoclássica de Chicago. Nesse sentido, Devlin esclarece que,

[a]pesar de a Escola de Chicago e a Escola pós-Chicago ${ }^{23}$ certamente terem convencido a Suprema Corte da importância das considerações sobre eficiência - em grande parte através da demonstração das enormes perdas decorrentes da abordagem E-C-D [Estrutura-CondutaDesempenho] - o fator explanatório último [da mudança de orientação na jurisprudência antitruste da Suprema Corte norteamericana] foi uma guinada na ideologia política. Tal guinada, por sua vez, adveio de uma mudança de atitude das pessoas em relação à estrutura da indústria e aos processos de livre mercado ${ }^{24}$. (2010, pp. 568-569, tradução livre, grifo nosso)

A guinada ideológica a que se refere Devlin é reflexo do momento histórico pelo qual passavam os Estados Unidos. Os pressupostos da Escola de Chicago - largamente baseados na ideia de que as forças de livre mercado são capazes de gerar os mais eficientes e, portanto, melhores resultados - encontraram amplo respaldo no conservadorismo econômico em ascensão no país (DEVLIN, 2010). O modelo de mercado eficiente ${ }^{25}$ apresentava grande sinergia e complementaridade com os ideais de liberalização econômica, livre comércio e redução do Estado, pregados à época. Ademais, num contexto em que as empresas norte-americanas perdiam espaço doméstica e internacionalmente, argumentos pela eficiência se tornaram mais atraentes (KOVACIC \& SHAPIRO, 2000).

\footnotetext{
${ }^{23}$ Salomão Filho explica que "três são as teorias principais que, de diversos modos e em diversos campos, compõem essa visão pós-Chicago: a teoria dos mercados contestáveis (contestable markets), a teoria dos jogos e a teoria dos custos de transação (transaction costs), com suas diversas consequências econômicas pontuais" (2003, p. 23).

${ }^{24}$ Nos termos do autor: Although the Chicago and post-Chicago Schools certainly convinced the Court of the importance of efficiency concerns - largely by highlighting the enormity of losses associated with the $S$-C-P approach - the ultimate explanatory factor was a shift in political ideology. This shift, in turn, came from the public's changing attitude toward industry structure and free market processes.

${ }^{25}$ Segundo Hovenkamp, a teoria antitruste da Escola de Chicago pode ser resumida, brevemente, em dez pressupostos: (i) eficiência econômica - consistente basicamente em eficiência alocativa e produtiva - deve ser o único objetivo das normas antitruste; (ii) a maioria dos mercados é competitivo, ainda que possua, relativamente, poucos ofertantes; (iii) monopólios, quando existentes, tendem a se autocorrigir; (iv) barreiras "naturais" à entrada são mais imaginadas do que existentes, de fato; (v) economias de escala são substancialmente mais sutis do que os economistas até então acreditavam; (vi) uma empresa normalmente maximiza seus lucros quando empresas à montante e à jusante no mercado se comportam de maneira competitiva; (vii) agentes econômicos são maximizadores de lucro; (viii) a aplicação das normas antitruste deve se destinar às condutas apenas na medida em que são ineficientes, de modo que as práticas devem ser toleradas e encorajadas quando se mostrarem eficientes; (ix) ainda que os mercados sejam imperfeitos e tendam a resultados anticompetitivos, a intervenção governamental se justifica tão somente na medida em que promover melhorias, considerados os custos e benefícios; (x) a decisão de tornar o modelo de mercado eficiente como o único guia da política antitruste não é político, uma vez que não considera a maneira como a riqueza e a propriedade são distribuídas na sociedade, mas só visa promover o aumento de riqueza geral (2005, p. 62-63).
} 
Assim, a conjugação de um momento histórico oportuno com um robusto e atraente arsenal teórico é fundamental para explicar o poder que passou a ser exercido pela Escola de Chicago a partir das últimas décadas do século XX e que se estende até os dias de hoje. De fato, as teorias econômicas pós-Chicago não representam uma ruptura com a Escola em comento, mas envolvem certa flexibilização de suas perspectivas analíticas. A introdução de novas teses e hipóteses - como a teoria dos jogos e a teoria dos custos de transação - insere novas nuances na teoria econômica aplicada à defesa da concorrência, dando lugar a análises mais ambíguas e complexas (HOVENKAMP, 2005). Não obstante - ou talvez mesmo em função da complexidade desses novos instrumentos analíticos -, “é inegável que a Escola de Neoclássica de Chicago é hoje prevalente na doutrina econômica que trata da questão concorrencial" (SALOMÃO FILHO, 2003, p. 22).

A elegância e praticidade da teoria da Escola de Neoclássica de Chicago pode ser considerado um dos aspectos a explicar sua popularidade ainda atualmente. Mas outro elemento chama a atenção quando se reflete sobre seu forte apelo: a já mencionada ideia de que a eficiência como meta e norte da política antitruste é absolutamente destituída de cunho político. Mais especificamente, argumenta-se que, sem a eficiência como guia, a defesa da concorrência ficaria destituída de qualquer embasamento objetivo e se tornaria um "instrumento maleável, sujeito aos desígnios idiossincráticos de quem quer que a aplicasse. Seus aplicadores ficariam, portanto, sem um padrão bem definido a partir do qual poderiam julgar as condutas sob seu escrutínio"26 (DEVLIN, 2010, p. 562, tradução livre).

A pretensão de objetividade e neutralidade da política antitruste por meio da aplicação da teoria econômica - frequentemente tomada como sinônimo da teoria desenvolvida pela Escola Neoclássica de Chicago - será endereçada, mais adiante, nesse trabalho. No entanto, vale, desde já, registrar a reflexão de Hovenkamp ao discutir a incursão de outras teorias econômicas na teoria desenvolvida pela Escola de Chicago, exigindo maior flexibilidade na aplicação dos pressupostos dessa última. Isso porque, embora se refira, aqui especificamente, à relevância de outras teorias econômicas e não a

\footnotetext{
${ }^{26}$ Nos termos do autor: Long-run efficiency is the exclusive goal of modern competition enforcement. Without the guiding norm of efficiency, antitrust policy would become untethered from any recognizable policy foundation. It would become a mallable tool subject to the idiosyncratic whim of whoever wished to enforce it. Courts would lack a well-defined standard by which to judge a challenged conduct.
} 
outros fatores a serem ponderados na análise antitruste, o raciocínio do autor designa a necessária complexidade do contexto em que a defesa da concorrência está inserida:

A Escola de Chicago oferece simplicidade, elegância e, comumente, respostas relativamente simples a questões de defesa da concorrência. As alternativas a ela são quase sempre mais caóticas, mais expansivas e menos determinadas. Mas as políticas têm de refletir o mundo em que vivemos e o mundo é um lugar caótico ${ }^{27}$ (2005, p. 71, tradução livre).

\subsubsection{Breve retrospectiva histórica: algumas conclusões}

Uma breve análise histórica da política antitruste dos Estados Unidos - um dos berços da defesa da concorrência e ainda hoje uma das jurisdições mais influentes nessa seara - ilustra como a teoria econômica, ao mesmo tempo em que está profundamente entrelaçada com controle antitruste, mantém uma relação plástica e dinâmica com ele.

A defesa da concorrência - como política pública que é -, afinal, interage com uma série de outros fatores, que não estritamente econômicos. A ilusão de que é possível compreendê-la e aplicá-la a partir de uma ótica tão somente lastreada na teoria econômica não encontra ressonância na própria história dessa disciplina. Como se pôde verificar, os objetivos por trás da elaboração das normas concorrenciais foram os mais diversos. $\mathrm{O}$ mesmo se pode afirmar sobre as teorias que lhe embasaram. Igualmente, a relação entre objetivos, embasamento teórico e contexto histórico levou a uma aplicação variada da defesa da concorrência, ao longo do tempo.

Além de o controle antitruste exigir outras considerações que não apenas de cunho econômico, importa ressaltar que ele foi informado por diferentes teorias econômicas, as quais foram, inclusive, atribuídos diferentes pesos. Mesmo em períodos em que a teoria econômica se pretendeu absoluta, como único determinador de conteúdo e norte da política antitruste, observa-se uma preocupação com elementos alheios a uma ponderação abstrata da teoria econômica, relacionados ao contexto, à realidade, em que a política em questão encontrava-se inserida.

\footnotetext{
${ }^{27}$ Nos termos do autor: The Chicago School offers simplicity, elegance and often relatively easy answers to antitrust questions. The alternatives are almost always messier, more expansive, and less determinate. But policy has to reflect the world we live in, and the world is a messy place.
} 
Esse fenômeno, identificado ao longo da história da defesa da concorrência norteamericana, não é fortuito. Isso porque, se, por um lado, a teoria econômica é uma face necessária, intrínseca, do controle antitruste, por outro, este último é colocado em prática através da aplicação de normas, de leis, que requerem, naturalmente, ponderações de cunho jurídico. Dito de outro modo, a defesa da concorrência se dá, em grande medida, através da aplicação, pelo Estado, do direito concorrencial. Este, ainda que permanentemente informado pela disciplina econômica, com ela não se confunde. Isto é, embora a interação entre o direito concorrencial e a teoria econômica revele-se positiva sob diferentes ângulos, seus limites devem ser respeitados.

Para entender como a teoria econômica se relaciona com o direito concorrencial, sem que com isso a autonomia de cada uma dessas disciplinas reste comprometida, a próxima seção se debruça sobre a teoria dos sistemas, de Niklas Luhmann. Esclarecida a forma pela qual tal relação ocorre, o trabalho se volta a explorar tanto seus benefícios, quanto seus limites.

\subsection{Como o direito se relaciona com a teoria econômica no controle antitruste: uma análise a partir da teoria dos sistemas de Niklas Luhmann}

A história da defesa da concorrência nos Estados Unidos, apresentada acima, evidenciou que a interação entre teoria econômica e direito é inerente ao controle antitruste, na medida em que este é colocado em prática através da aplicação de normas permeadas por conceitos absorvidos da teoria econômica. Esse fenômeno não se restringe ao direito concorrencial norte-americano. No Brasil, isso é claro tanto a partir da leitura da Lei $\mathrm{n}^{\circ} 12.529$ de 30 de novembro de 2011, que disciplina a defesa da concorrência no país, quanto da própria Constituição de 1988, a qual prevê que a "lei reprimirá o abuso do poder econômico que vise a dominação dos mercados, à eliminação da concorrência e ao aumento arbitrário dos lucros" (Constituição Federal, Artigo 173, § $4^{\circ}$ ).

Ora, a definição do que é poder econômico, a sua forma de exercício, o que caracteriza eliminação da concorrência, ou o ponto a partir do qual ocorre aumento arbitrário de lucros exige que se faça ponderações de caráter econômico, empregando ferramentas (raciocínios e conceitos) desenvolvidas pela teoria econômica. O mesmo se 
pode dizer de conceitos empregados pela referida lei, como, por exemplo, a noção de mercado relevante ${ }^{28}$.

Conforme mencionado, a indeterminação normativa, somada à referência a conceitos econômicos nos textos legais, faz do direito da concorrência um ramo singular do direito, em que há uma constante e necessária intersecção entre as searas jurídica e da teoria econômica. O diálogo entre essas duas disciplinas - que permite que elas se relacionem, ao mesmo tempo em que a autonomia de ambas resta garantida - pode ser explicado pela teoria dos Sistemas de Niklas Luhmann.

A seguir, portanto, o presente trabalho explora, num primeiro momento, $\mathrm{o}$ conceito de sistema; a capacidade dele de se autorreproduzir a partir de operações, códigos e programas próprios; a autonomia de que desfrutam os sistemas autopoiéticos; e a possibilidade desses sistemas se comunicarem com seu ambiente, sem que com isso comprometam sua autodeterminação. Em um segundo momento, ele se debruça sobre sistemas de comunicação, sobre a sociedade como sistema social de maior abrangência e complexidade e, finalmente, sobre os sistemas parciais funcionais existentes nas sociedades modernas. É a partir dessas noções que o trabalho explica, na sequência, como o direito constitui um sistema funcional, capaz de se diferenciar de seu ambiente através de sua função e de seus códigos e programas próprios, ao mesmo tempo em que mantem a capacidade de se relacionar com outros sistemas, tal como a teoria econômica. A compreensão do controle antitruste como um acoplamento estrutural entre o direito concorrencial e a teoria econômica permitirá, então, vislumbrar tanto os benefícios quanto as limitações da relação entre esses dois sistemas.

\footnotetext{
${ }^{28}$ A relevância que a teoria econômica tem para a aplicação dos termos utilizados pela Lei no 12.529/2011 é ilustrada pelo termo "mercado relevante", o qual aparece em múltiplas ocasiões no diploma legal em questão. Trata-se de termo essencial para a realização de operações básicas do direito da concorrência, na medida em que serve tanto à definição de infração à ordem econômica (artigo 36, II e $\S 2^{\circ}$ ), quanto à identificação de atos de concentração que devam ser proibidos (artigo $88, \S 5^{\circ}$ ). A importância da teoria econômica para a delimitação desse conceito, por sua vez, é evidenciada por Gaban e Domingues, segundo os quais: "[p]ara a delimitação do mercado relevante podem ser utilizados alguns testes econômicos, entre os quais o teste do 'monopolista hipotético'. (...) Na mesma linha, também podem ser utilizados testes de elasticidade preço da demanda, como também da elasticidade cruzada preço da demanda (...).” (2012, pp. 93-94)
} 


\subsubsection{Noções gerais acerca da Teoria dos Sistemas}

A Teoria dos Sistemas de Luhmann define sistema como um conjunto de elementos interconectados que formam um todo organizado e que, assim, se distinguem dos ruídos que formam seu ambiente. Mais especificamente, um sistema é, composto por elementos $^{29}$ (unidades indecomponíveis) e pela relação entre esses elementos (estrutura), a qual, por sua vez, caracteriza a própria organização do sistema e, dessa maneira, confere unidade a este último.

É importante reforçar, porém, que desse processo não decorre uma noção de unidade enquanto forma rígida ou estática, contrapondo-se à ideia de conteúdo ou contexto, mas sim de unidade como algo resultante da diferenciação entre o sistema e seu ambiente $^{30}$. A noção de diferenciação entre sistema e seu ambiente é, ela própria, ponto de partida da teoria e permite compreender uma característica básica dos sistemas: na medida em que se diferenciam de seu ambiente, os sistemas permitem um corte da realidade a ser absorvida por seu observador, constituindo, portanto, em um redutor da complexidade do mundo (LUHMANN, 2007).

Mas, como observa o próprio Luhmann, sua teoria, mais do que constatar a existência de sistemas, discorre sobre sistemas sociais autorreferenciado (1997, p. 13). Nesse ponto, as bases teóricas do próprio autor são elucidativas: Luhmann parte do conceito de "autopoiése" - introduzido pelos biólogos Maturana e Varela, para caracterizar os seres vivos enquanto sistemas que produzem a si próprios - para desenvolver uma teoria sociológica sobre os sistemas.

De acordo com referido autor, um sistema autopoiético é aquele que produz ele próprio, como unidade, tudo aquilo que usa como unidade, ou seja, é um sistema que constitui os elementos e estrutura que o constituem, através dos elementos e estrutura que o constituem (LUHMANN, 2007). Ao fazer isso, ele estabelece limites/fronteiras que não existem no seu ambiente, gerando um fechamento e, consequentemente, uma unidade

\footnotetext{
${ }^{29}$ Segundo Luhmann, "[l]os elementos son informaciones, son diferencias que en el sistema hacen una diferencia. En ese sentido son unidades de uso para producir nuevas unidades de uso —para lo cual no existe ninguna correspondencia en el entorno" (2007, p. 45).

${ }^{30}$ Para Luhmann, ao falar de sistemas, há que se pensar em distinções e não em objetos: “El concepto de forma ya no sólo se distingue del concepto de contenido, y ya no sólo del concepto de contexto; uma forma puede residir em que algo es distinto a todo lo demás, como también en que algo es distinto a su contexto (...) Con ayuda de esta conceptuación - diseñada para el desarrollo del cálculo de las formas que procesan distinciones - puede interpretarse también la distinción sistema/entorno”. (2007 pp. 40-43)
} 
sistêmica. Dessa forma, o sistema - diferenciando-se de seu ambiente e de nenhuma forma a despeito dele - tem a capacidade de organizar a si próprio e de construir sua própria ordem (LUHMANN, 2007) ${ }^{31}$.

Um sistema fechado não implica a ausência, a negação, de um ambiente, nem tampouco uma completa autodeterminação, mas sim o fato de que todas as operações do sistema sempre reproduzem esse último. Sistemas autopoiéticos só podem se reproduzir por meio de comunicação autorreferenciada, viabilizada pela sua abertura cognitiva e seu fechamento operacional.

Enquanto a primeira (abertura cognitiva) designa que o sistema é aberto ao estímulo de ruídos ou perturbações provenientes do ambiente, o fechamento operacional implica a existência de um controle temático dos processos comunicativos, realizado a partir da auto-observação e da autodescrição, os quais determinam o que pode se comunicar com o que. Mais precisamente, após observar o ambiente e suas demandas, bem como a si próprio e sua capacidade de reduzir a complexidade, o sistema seleciona as perturbações e irritações externas que são reconhecidas pelo sistema com base em seu código binário e programas próprios. Luhmann esclarece esses conceitos:

Os códigos não são representações de uma realidade de valor, mas sim simples regras de duplicação. Para tudo aquilo que em seu âmbito de aplicação (definidos pelos próprios códigos) aparece como informação (confeccionada por eles próprios), torna-se disponível um correlato negativo. Por exemplo: verdadeiro/não-verdadeiro; amado/não-amado; proprietário/não-proprietário; aprovado/reprovado; governante/súdito; etc. Consequentemente, tudo o que está compreendido na forma do código aparece como contingente, como possível também de outra maneira. Por isso, na prática, surge a necessidade de ter regras de decisão que fixem as condições mediante as quais o valor (ou valor oposto) é associado de maneira correta ou falsa. Chamamos tais regras de programas. (2007, p. 594, tradução livre, grifos nossos) $)^{32}$

\footnotetext{
${ }^{31}$ Mais uma vez, aqui não se refere a constituição de uma certa forma. A autopoiese se dá pela capacidade do sistema de realizar ele próprio, sua diferenciação do ambiente. Nos termos de Luhmann: "[n]o debe concebirse la autopoiesis como la producción de una determinada forma (Gestalt). Lo decisivo más bien está en la producción de una diferencia entre sistema y entorno." (2007, p. 45)

${ }^{32}$ Nos termos de Luhmann: "Los códigos no son representaciones de una realidad del valor sino simples reglas de duplicación. Para todo lo que en su ámbito de aplicación (definido por ellos mismos) aparece como información (constituida por ellos mismos), vuelven disponible un correlato negativo. Por ejemplo: verdadero/no-verdadero; amado/no-amado; propietario/no-propietario; aprobado/reprobado; gobernador/súbdito; etc. Consecuentemente, todo lo que queda comprendido con la forma del código aparece como contingente, como posible también de otra manera. Por eso en la práctica surge la necesidad de tener reglas de decisión que fijen las condiciones mediante las cuales el valor (o el valor opuesto) queda asociado de manera correcta o falsa. Llamamos programas a tales reglas. "(2007, p. 594.)
} 
É desse modo que todo sistema autopoiético controla, em cada operação, suas próprias possibilidades de negação e, assim, constrói sua própria ordem a partir do ruído ${ }^{33}$ (LUHMANN, 2007). E é por isso que o conceito de fechamento operacional (ou autorreferenciado) - ao possibilitar a distinção entre "esta dependência recursiva da operação em relação a ela própria das indiscutivelmente persistentes dependências em relação ao ambiente" 34 (LUHMANN, 2007, p.44) - pode ser considerada como um dos aspectos mais relevantes da teoria sobre sistemas autorreferenciados (LUHMANN, 1987).

Segundo Luhmann, toda a abertura do sistema pressupõe seu fechamento, o qual está, por sua vez, invariavelmente relacionado à própria autonomia do sistema. Dito de outro modo, todas as relações externas entre um sistema autopoiético e seu ambiente são dadas de maneira inespecífica, e toda especificação realizada pela auto-observação e autodescrição pressupõe autonomia do sistema. Nesse sentido, Guerra Filho esclarece que a clausura - circunstância de o sistema ser "fechado", do ponto de vista de sua organização, não havendo "entradas" (inputs) e "saídas" (outputs) para o ambiente, pois os elementos interagem no sistema e através dele - é condição de autonomia do sistema (1997).

Na medida em que são operacionalmente fechados e autônomos, os diferentes sistemas mantêm uma relação entre si através de acoplamentos estruturais, sem que isso mine a sua capacidade de autodeterminação. Os acoplamentos estruturais podem ser compreendidos como a ponte entre um sistema e outro, através da qual se promove a troca de informação entre eles. Não há que se pensar, segundo Luhmann, que, a partir de tal acoplamento, o ambiente contribua com operações ou quaisquer outros componentes para a reprodução de um sistema (1992). Mesmo porque,

os acoplamentos estruturais pressupõem que todo sistema autopoiético opera como sistema determinado pela estrutura, ou seja, como sistema que apenas através de suas próprias estruturas pode determinar suas próprias operações. $\mathrm{O}$ acoplamento estrutural, portanto, exclui que dados existentes no ambiente

\footnotetext{
${ }^{33}$ Nos termos de Luhmann, “el sistema (...)puede organizarse por si mismo y construir su proprio orden: “order from noise”. (2007, p. 44)

${ }^{34}$ Nos termos de Luhmann: Como pueden distinguirse esta dependencia recursiva de la operación respecto a si misma de las indiscutiblemente persistentes dependencias respecto al entorno? (...) Estas determinaciones conceptuales aclaran en primer lugar el concepto - hoy usado con frecuencia - de clausura operativa (o autorreferencial) del sistema.
} 
possam especificar - conforme suas estruturas próprias - o que ocorre no sistema $^{35}$. (LUHMANN, 2007, p. 73, tradução livre)

Enquanto espaço de trânsito entre sistemas, os acoplamentos estruturais canalizam as perturbações, irritações, surpresas e desapontamentos, levando os sistemas a lidar com eles (LUHMANN, 1992). Em outras palavras, eles "fornecem um fluxo contínuo de desordem em face do qual o sistema mantém ou muda sua estrutura" ${ }^{\text {"6 }}$ (LUHMANN, 1992, p. 1433). Tais acoplamentos têm, dessa forma, um efeito duplo: por um lado, a irritação selecionada é admitida e utilizada pelos sistemas acoplados (MATTHEIS, 2012, p. 631), por outro, a maioria dos fatos ambientais (environmental facts) é excluída da esfera de relevância imediata dos sistemas (LUHMANN, 1992, p. 1433).

Não se pode deixar de reiterar, porém, que a informação que entra no sistema não o faz por vias a ele externas. As noções de sistemas operacionalmente fechados e acoplamento estrutural implicam que a seleção da informação é sempre construída internamente ao sistema (LUHMANN, 1992). Nesse contexto, “[m]esmo em sua irritabilidade, os sistemas (...) são completamente autônomos"37 (LUHMANN, 2007, p. 87).

\subsubsection{Sistemas sociais}

Ainda que a teoria dos sistemas, acima descrita, se aplique a diferentes tipos de sistemas, conforme adiantado, Luhmann deu ênfase especial a seu desenvolvimento sob o ponto de vista sociológico. Isto é, sua obra se dedica eminentemente aos sistemas sociais, cujo elemento básico é a comunicação. Mais especificamente, o autor refere-se a

\footnotetext{
${ }^{35}$ Nos termos de Luhmann, os acoplamentos estruturais "presuponen que todo sistema autopoiético opera como sistema determinado por la estructura, es decir, como sistema que sólo a través de las propias estructuras puede determinar sus propias operaciones. El acoplamiento estructural, entonces, excluye el que datos existentes en el entorno puedan especificar - conforme estructuras propias - lo que sucede en el sistema".

${ }^{36}$ Nos termos do autor: "Aun en su irritabilidad, los sistemas - tanto de conciencia como los de comunicación - son completamente autónomos.”

${ }^{37}$ Segundo Luhmann: "El lado del acoplamento estructural que es interno al sistema puede indicarse com el concepto de irritación - moléstia, pérturbación. Los sistemas autpoiéticos reaccionan sin remedio a irritaciones negativas, es decir, a irritaciones no tipificables. (...) Aun en su irritabilidad, los sistemas (...) son completamente autónomos. Las irritaciones surgen de uma confrontación interna de acontecimentos (en un primer momento no especificados) con possibilidades propias, sobretodo con estructuras estabilizadas, con expectativas." (2007, p. 87, grifo nosso)
} 
três tipos de sistemas sociais, ou sistemas de comunicação: i) interação ${ }^{38}$; ii) organização ${ }^{39}$; e iii) sociedade $^{40}$. (LUHMANN, 2007)

Dentre eles, a sociedade é o sistema de maior amplitude e complexidade, haja vista que abarca todas as comunicações existentes, as quais incluem não apenas os próprios sistemas de interação e as organizações, mas também os sistemas parciais, isto é, subsistemas sociais, com seus próprios códigos binários.

Na teoria luhmanianna, a sociedade não se caracteriza, portanto, por uma determinada "essência", nem, muito menos, por uma determinação moral, mas unicamente pela operação que a produz e reproduz: a comunicação ${ }^{41}$ (LUHMANN, 2007). Mais do que isso, importa notar que, segundo tal teoria, as sociedades se transformam, à medida que evoluem ${ }^{42}$. Desse modo, são distintas as formas de ${ }^{38}$ A interação é o mais simples deles e exige a presença dos indivíduos - os quais se percebem mutuamente
- em um mesmo lugar e momento. Dada sua precariedade, tal sistema serve apenas para reduzir pequenas
complexidades. (LUHMANN, 2007)
${ }^{39}$ A organização, por sua vez, demonstra melhor capacidade de garantir as expectativas de comportamento
(responsáveis por delimitar as possibilidades de ação, uma vez que são o arcabouço seletivo das
comunicações). Nesse sentido, é um sistema que já dispõe de um grau de estabilidade maior. Por outro
lado, no sistema de organização, já não basta a presença. É a filiação - a diferenciação entre membro/não-
membro de uma organização - que deflagra o surgimento desse sistema. Na medida em que o membro
admite reprimir a espontaneidade de sua conduta e guia-la segundo determinadas pautas de comportamento,
garante-se estabilidade ao sistema.

${ }^{40}$ Luhmann abandona o conceito antropocêntrico de sociedade como aglomerado de indivíduos - como conjunto de homens - que agem (seja para realização de certos interesses, seja para realizar valores por eles compartilhados). Na sociedade luhmaniana o homem está fora, o homem é ambiente (LUHMANN, 2007). Afinal, a sociedade não é uma estrutura biopsíquica. Ainda que Luhmann reconheça que, onde a sociedade é a própria comunidade, pode haver uma coincidência de valores, ele esclarece que isso não é necessário. Da mesma forma, ele descola a sociedade da ideia territorial. A noção de sociedade de Luhman não é, enfim, fundada nem no homem, nem na cultura, nem no estado. Para ele, a sociedade é o sistema social mais abrangente, cujo elemento essencial é a comunicação. Isto é, o sistema social é um sistema de comunicação (LUHMANN, 2007).

${ }^{41}$ Nos termos de Luhmann: "El sistema sociedad no se caracteriza entonces por una determinada 'esencia', ni mucho menos por una determinada moral (propagación de la felicidad, solidaridad, nivelación de condiciones de vida, integración por consenso racional, etcétera), sino únicamente por la operación que produce y re-produce a la sociedad: eso es la comunicación." (LUHMANN, 2007, p. 48.)

${ }^{42}$ Aqui cabe esclarecer a noção de evolução segundo a teoria luhmanniana. Conforme nota Marcelo Neves, a evolução, segundo Luhmann, é "a transformação do improvável no provável [e] ocorre quando aquilo que é desviante passa a integrar a estrutura do respectivo sistema" (NEVES, 2006, p. 1). Não se trata, portanto, da passagem para um maior grau de felicidade, da realização de um ideal ou valor, nem tampouco do progresso (NEVES, 2006). Da mesma forma, Luhmann rejeita a evolução tal como proposta por Hegel (início e fim da história, com o alcance de harmonia e paz social), bem como a evolução em termos materiais como em Marx (NEVES, 2006). De acordo com Luhmann, a evolução ocorre quando surge algo no sistema como ele não estava previsto inicialmente, aumentando a complexidade e levando ao aumento de possibilidades. Nesse caso, amplia-se o desnível entre as possibilidades disponíveis e aquelas que se atualizam (NEVES, 2006). Para que possa se realizar, se ver completa, a evolução tem de preencher "três condições vinculadas reciprocamente: variação, seleção e restabilização ou retenção" (NEVES, 2006, p. 2). A primeira delas (variação) ocorre no plano dos elementos (comunicações vinculadas às ações). Aqui, tem lugar uma "reprodução desviante de elementos por elementos do sistema, [levando a] uma comunicação inesperada, surpreendente" (LUHMANN, 2007, p. 358). No caso de pura variação, as estruturas não admitem o desvio, de modo que a prática social em questão pode ser facilmente relegada ao esquecimento. 
diferenciação entre os sistemas e seu ambiente nas sociedades arcaicas, pré-modernas e modernas.

Se nas sociedades arcaicas a diferenciação primária é a segmentária - o que significa que os sistemas parciais se distinguem por meio da descendência ou residência, ou ambos -, na formação social pré-moderna a diferenciação entre os sistemas é hierárquica: há uma desigualdade de nível entre eles. Mais especificamente, na sociedade pré-moderna, é a cosmovisão moral-religiosa, o poder ou a intersecção entre esses dois elementos que informa a sociedade e seus subsistemas, de maneira que a autopoiése dos sistemas parciais, como, por exemplo, o direito, resta comprometida.

Nas sociedades modernas, por outro lado - em parte devido à insustentável condição de estratificação, já pressionada por níveis de complexidade superiores (NEVES \& RODRIGUES, 2012) -, emerge uma nova forma de diferenciação, baseada na função do sistema.

Segundo Luhmann, a função consiste na observação do sistema total pelo sistema parcial, marcando - com base na função que o sistema diferenciado desempenha para o sistema total - uma diferença entre o sistema parcial e seu ambiente (2007). Sob outro ponto de vista, pode-se dizer que a análise funcional trabalha com os problemas que emergem na sociedade e que exigem uma solução ${ }^{43}$. Nesse contexto, e tendo por base o primado de sua função, "os sistemas funcionais alcançam um fechamento operacional e formam, assim, sistemas autopoieticos no interior do sistema autopoietico da sociedade" $(2007, \text { p. 592-593, tradução livre })^{44}$.

\footnotetext{
A seleção, por sua vez, se dá no plano das estruturas. Ela "elege as referências de sentido que tenham valor para formar estruturas, idôneas para o uso repetido, capazes de construir e condensar expectativas" (LUHMANN, 2007, p. 358). Nesse segundo momento, aquilo que era desviante e implicava variação passa a ser incorporado a certas estruturas da sociedade. No entanto, o fato de estar na estrutura não significa que faça parte da identidade do sistema. Para tanto tem de haver a restabilização. É ela (restabilização) que ocorre no plano de identidade ou unidade, figurando como equivalente à retenção no plano biológico. Ela "se refere ao estado do sistema que está evoluindo depois de uma seleção que resultou positiva ou negativa" (LUHMANN, 2007, p. 358). A ocorrência da restabilização significa que a estrutura de permanência do próprio sistema social passa a ser caracterizada a partir daquele elemento.

${ }^{43}$ Nos termos de Luhmann, "[d]iferenciación funcional significa que el punto de vista de la unidad bajo el cual se há diferenciado uma diferencia de sistema/ entorno es la función que el sistema diferenciado (y no su entorno) desempeña para el sistema total (...) La función se halla em referencia a um problema de la sociedade - no en la autorreferencia o en el automantenimiento del sistema funcional" (Luhmann, 2007, p. 591)

${ }^{44}$ Nos termos de Luhmann: "los sistemas funcionales alcanzan una clausura operativa y forman así sistemas autopoiéticos al interior del sistema autopoiético de la sociedad. ”(2007, p. 592-593.)
} 
Diferentemente do que ocorre nas sociedades pré-modernas, portanto, na sociedade moderna, a sociedade, como sistema social mais amplo e complexo, abarca sistemas parciais autorreferenciados, baseados num fechamento operacional recursivo, que têm sua função como ponto de referência inconfundível (LUHMANN, 2007). Tais sistemas estão voltados à reprodução de suas próprias operações, à determinação de suas "próprias identidades (...) através de uma semântica elaborada de reflexão, de autonomia, de dar sentido a eles mesmos" (2007, p. 590, tradução livre $)^{45}$.

De fato, uma vez que cada sistema funcional é diferenciado para cumprir uma função específica, a diferença entre os problemas de referência se acentua (LUHMANN, 2007). Contudo, mesmo que reste enfatizada a diferença entre sistemas de função, os sistemas, nessa diferença, são iguais. É dizer, o sistema total renuncia ao estabelecimento de uma ordem de relações entre os sistemas de função (LUHMANN, 2007). Isso não significa que a diferenciação funcional garanta oportunidades iguais para todos os sistemas funcionais (LUHMANN, 2007), mas sim que, no plano do sistema total da sociedade, não é possível estabelecer uma hierarquia universalmente válida entre as funções, que seja vinculante para todos esses sistemas (LUHMANN, 2007).

É nesse sentido que Luhmann afirma que, como consequência da elaboração, por cada sistema funcional, de seus mecanismos reprodutivos próprios - que o define e o diferencia dos demais -, a sociedade moderna tem caráter multicêntrico. Nela, um sistema não determina o outro, mas há uma série de subsistemas parciais que se autodeterminam.

Importa destacar que, para a autopoiese dos sistemas funcionais possa ocorrer, não basta ao sistema orientar-se por sua função. Conforme lembra Luhmann, embora "mediante sua função os sistemas funcionais se estabeleçam na sociedade e com a descrição de sua função se dirijam à sociedade, esses sistemas também precisam, para formar sua própria autopoiese, de outra forma de operação, de um código binário" (2007, p. 593, tradução livre) $)^{46}$.

\footnotetext{
${ }^{45}$ Nos termos de Luhmann: "cada sistema parcial debe definirse a sí mismo frente a los otros mediante una diferencia de rango para sólo asíllegar a la identidad propia; en el caso de la diferenciación funcional cada sistema de función determina su propia identidad - y esto sin excepción a través de una semántica elaborada de reflexión, de autonomía, de darse sentido a sí mismo."

${ }^{46}$ Nos termos de Luhmann: "mediante su función los sistemas funcionales se establecen en la sociedad y con la descripción de su función se remiten a la sociedad, estos sistemas necesitan además para formar su propia autopoiesis otra forma de orientación, un código binario."
} 
Tais códigos, já mencionados anteriormente, não são representações de uma realidade de valor, senão simples regras de duplicação. Afinal, os sistemas de função não são teleológicos, mas "referem todas as suas operações a uma distinção entre dois valores - precisamente aqueles do código binário - e com isso asseguram sempre a possibilidade de que uma comunicação passe para o valor oposto"47 (LUHMANN, 2007, p. 593, tradução livre). É com base em seus códigos e programas - os quais servem de regras que determinam as condições sob as quais um valor ou seu oposto será associado como correto ou falso - que os sistemas funcionais articulam sua autopoiese (LUHMANN, 2007).

Finalmente, cabe esclarecer que as funções dos sistemas em questão são especializadas e não-intercambiáveis. Apesar de não assegurar oportunidades equivalentes para todos os sistemas de função, a diferenciação funcional implica que, para cada sistema - e tão somente para ele -, sua própria função goze de prioridade e todas as demais funções lhe sejam subordinadas. É o que Luhmann chama de primado funcional (2007). "Cada sistema funcional pode desenvolver apenas sua própria função. Nenhum sistema pode intervir no lugar do outro em caso de emergência, nem mesmo complementá-lo em continuidade" (LUHMANN, 2007, p. 604) ${ }^{48}$.

Isso não significa de forma alguma que os sistemas funcionais não se comuniquem através de acoplamentos estruturais. Os sistemas funcionais tais como concebidos pela teoria luhmanniana não são autistas ou isolacionistas. As irritações e perturbações canalizadas por esses acoplamentos possibilitam que o sistema aprenda e transforme suas estruturas (LUHMANN, 1992). Porém, são os códigos e programas do próprio sistema que determinam o que é por ele assimilado e como isso ocorre.

Conforme explica Neves, acoplamentos estruturais implicam uma influência concentrada entre sistemas e, concomitantemente, uma forte seletividade em face das influências, excluindo umas e viabilizando outras. Os sistemas permanecem observando os problemas e oferecendo-lhes soluções de acordo com seus critérios próprios, mas, através dos acoplamentos estruturais, a linguagem própria de cada sistema é traduzida na

\footnotetext{
${ }^{47}$ Nos termos de Luhmann: "Los sistemas de funciones no son nunca sistemas teleológicos. Refieren todas sus operaciones a una distinción entre dos valores - precisamente los del código binario-y con eso aseguran siempre la posibilidad de una comunicación de enlace que puede pasar al valor opuesto."

${ }^{48}$ Nos termos de Luhmann: "Cada sistema funcional puede desarrollar sólo la propia función. Ningún sistema puede intervenir en lugar de otro en caso de emergencia o siquiera complementarlo en continuidad."
} 
linguagem própria de outro. Isso se dá de acordo com os critérios do sistema em que a linguagem advinda do outro sistema pretende ter relevância. Dessa forma, os acoplamentos estruturais facilitam a compreensão recíproca dos sistemas, em princípio herméticos e opacos uns para os outros. Eles facilitam interpenetrações sem atingir, contudo, a autonomia operacional dos sistemas, antes as fortificando (NEVES, 2005).

\subsubsection{Direito como sistema funcional}

Nas sociedades modernas, o direito desponta como um sistema parcial funcional, na medida em que não apenas possui uma função específica, como também dispõe de código e programa próprios que permitem sua autopoiese. Em sua obra, Luhmann inclusive toma por base o sistema jurídico para esclarecer como um subsistema da sociedade pode se relacionar com seu ambiente e, ainda assim, manter seu fechamento operacional e, portanto, sua unidade.

Conforme exposto, eventos só podem manter sua qualidade de unidade elementar de um sistema através do fechamento operacional. Este, por sua vez, está estritamente relacionado à diferenciação funcional, a qual marca a distinção entre o sistema e seu ambiente com base na função que o sistema diferenciado desempenha para o sistema total.

Assim, se, na sociedade moderna, a função de um sistema diz respeito a como subsistemas sociais se especializam no tratamento de tipos específicos de problemas, o direito pode ser concebido como o sistema parcial que se volta à exploração de perspectivas conflitantes para a formação e reprodução de expectativas comportamentais congruentemente generalizadas (LUHMANN, 1988). Em outras palavras, para reduzir a complexidade do ambiente, o direito absorve a contingência do comportamento social, ao garantir certa congruência entre as expectativas de como os indivíduos vão se comportar, e a generalização dessas expectativas (GUERRA FILHO, 1997)

Mais especificamente, a diferenciação funcional do sistema jurídico ocorre por meio da distinção entre expectativas cognitivas - aquelas que se alteram quando comprovada a ausência de correspondência com a realidade - e normativas - aquelas que, comprovado o descasamento da expectativa com a realidade, implicam uma reação, uma crítica (LUHMANN, 1988). O direito usa, então, esta diferença para combinar o 
fechamento da autorreprodução e a abertura desse sistema em relação a seu ambiente. Nesse sentido, o direito é um sistema normativamente fechado - na medida em que apenas ele pode conferir qualidade normativa legal a seus elementos e, assim, constituí-los como elementos - e cognitivamente aberto - na medida em que depende, em cada um de seus elementos e em sua constante reprodução, da capacidade de determinar se certas condições foram ou não atendidas (LUHMANN, 1987).

O processamento de aspectos cognitivos e normativos do sentido, por seu turno, se dá por meio da atuação conjunta do programa e código binário próprios. No sistema jurídico, a estrutura do sistema consiste de programas condicionais que devem ser cognitivamente aferidos (condicionamento que estabelece uma relação "se A/então B" entre as condições) ${ }^{49}$ e de atribuição de qualidade normativa (esquematização binária lícito/ilícito).

Aqui, vale ressaltar que o código binário jurídico - da mesma forma como o código binário de outros sistemas parciais funcionais - não é uma representação de uma realidade de valor, mas sim uma regra de duplicação, em que o correlato negativo da informação confeccionada pelo próprio sistema torna-se disponível. Logo, na sociedade moderna, o direito não se identifica com normas consideradas verdadeiras e imutáveis, como é o caso nas sociedades arcaicas ou pré-modernas ${ }^{50}$. Assim como a decidibilidade ${ }^{51}$, a alterabilidade revela-se uma característica do sistema jurídico moderno. Por outro lado, nesse contexto, não se pode perder de vista que a unidade e autonomia do direito estão estritamente relacionadas ao fechamento operacional do sistema, que determina, ele próprio, através de seu programa e código, o que é juridicamente relevante.

\footnotetext{
${ }^{49}$ Para ilustrar como se dá o condicionamento do sistema jurídico, Luhmann recorre a um exemplo do direito alemão. Segundo ele, o Código Civil alemão determina que a capacidade jurídica de uma pessoa física passa a existir a partir de seu nascimento. Tal condição tem de ser aferida cognitivamente: aquele que não nascer não possui capacidade jurídica. Qualquer tentativa de introduzir uma expectativa normativa aqui - processando esse dispositivo, por exemplo, como se uma pessoa tivesse a obrigação de nascer -lançaria uma confusão sobre todo o sistema conceitual em que estão baseadas as decisões jurídicas.

${ }^{50}$ Marcelo Neves esclarece como se dá a evolução do direito, segundo a teoria luhmanniana. Nas sociedades arcaicas não há um procedimento de aplicação jurídica, não há uma distinção entre ação e norma. O direto não se aplica, ele se afirma expressivamente a cada momento. $\mathrm{O}$ direito é considerado algo naturalizado. Esse direito tem variação limitada. Há inquestionabilidade da identidade. No direito das sociedades das culturas antigas, há aumento de variação. Mas o direito está assentado numa semântica abrangente, com moral e religião. Nesse nível o direito muda, mas isso se dá de maneira bastante imperceptível. O direito natural, por seu turno, pode ser considerado como a transição para a modernidade. Isso porque, enquanto no direito das sociedades da cultura antiga, as normas gerais são consideradas verdadeiras e imutáveis, aqui já se admite que há normas postas pelos seres humanos, ainda que estas estejam subordinadas ao direito natural.

${ }^{51}$ Conforme esclarece Marcelo Neves, de acordo com a teoria sistêmica de Luhman, na sociedade moderna a positividade do direito jaz no fato de o direito ser posto por decisão, permanentemente alterado por decisão, e autodeterminado (2006).
} 
Desse modo, na alocação da ação em programas e critérios jurídicos e na categoria lícito ou ilícito, há sempre um elemento de autorreprodução do sistema jurídico, que permite que o direito, em sua autonomia, desempenhe sua função. Conforme observa Neves,

\footnotetext{
a vigência jurídica das expectativas normativas não é determinado imediatamente por interesses econômicos, critérios políticos, representações éticas, nem mesmo por proposições cientificas, ela depende de processos seletivos de filtragem conceitual no interior do sistema jurídico (1994, p. 258)
}

Mais uma vez, vale destacar que isso não implica um autismo do sistema jurídico. Ao mesmo tempo em que o direito positivo fatorializa a autorreferência por meio de conceitos, ele assimila seu ambiente - sem ser diretamente influenciado por seus fatores de acordo com seus critérios próprios (NEVES, 1994). É, portanto, por meio de acoplamentos estruturais que o direito se comunica com outros sistemas parciais funcionais.

Diversos exemplos de acoplamento estrutural entre o sistema jurídico e outros sistemas podem ser identificados, sendo a Constituição, como acoplamento estrutural entre o direito e o sistema político, talvez o exemplo mais paradigmático entre eles. Por seu turno, também o controle concorrencial pode representar uma espécie de acoplamento estrutural entre sistemas - nesse caso, entre o direito e a teoria econômica. Afinal, conforme mencionado, a histórica relação entre teoria econômica e direito na defesa da concorrência está calcada na extensiva utilização de conceitos e raciocínios econômicos pelos responsáveis tanto por elaborar, quanto por aplicar as normas concorrenciais.

\subsubsection{Relação entre o direito e a teoria econômica no controle antitruste sob a ótica da teoria dos sistemas: algumas conclusões}

Partindo da histórica relação entre direito e teoria econômica no controle concorrencial, a presente seção buscou apresentar, através da Teoria dos Sistemas de Luhmann, como é possível que essas duas disciplinas se relacionem, sem que se confundam uma com a outra. Isto é, como pode a teoria econômica informar o direito concorrencial e sua aplicação, sem que a autopoiése do sistema jurídico reste comprometida pela violação de seus códigos, programas e critérios.

Para elucidar como o direito pode ser considerado um sistema com base na teoria em comento, primeiro procurou-se esclarecer o que Luhmann identifica como sistemas parciais funcionais existentes na sociedade moderna. Feito isso, e aclarado como estes 
sistemas se relacionam com seu ambiente (aqui incluídos outros sistemas), intentou-se demonstrar que o direito concorrencial, como subsistema jurídico, também se relaciona com seu ambiente por meio de acoplamentos estruturais. Mais especificamente, apresentou-se a relação entre o direito concorrencial e a teoria econômica como um acoplamento estrutural entre esses dois sistemas, através do qual eles trocam informações, sem deixar de processá-las de maneira autorreferenciada.

O pressuposto de que direito concorrencial e teoria econômica se diferenciam e se relacionam é ponto de partida para compreender tanto os aspectos positivos dessa relação, quanto seus limites, como se verá a seguir.

\subsection{Benefícios da relação entre o direito e teoria econômica no controle antitruste}

Os aspectos positivos da relação entre o direito e a teoria econômica na defesa da concorrência podem ser explicados tanto a partir da própria Teoria dos Sistemas, quanto de outras teorias que tratam dos benefícios da interdisciplinaridade entre o direito e outros ramos do conhecimento. A primeira parte dessa seção, portanto, volta-se, mais uma vez, a teoria luhmanniana, com vistas a desdobrar com maior atenção as decorrências dos acoplamentos estruturais. Já num segundo momento, o presente trabalho utiliza como referência especificamente a obra de Marcus Faro de Castro para analisar como a interdisciplinaridade pode auxiliar no combate ao que o autor chama de "abordagem conceitual do direito".

\subsubsection{As irritações promovidas por acoplamentos estruturais como meios de transformação direito}

Conforme observado, acoplamentos estruturais são os meios pelos quais sistemas autônomos se relacionam com seu ambiente. Guerra Filho, ao tratar dos desdobramentos dessa relação, explica como o direito, enquanto sistema autopoiético, desenvolve-se pelo estímulo de irritações provindas do ambiente social, ainda que apenas através de seus critérios próprios (1997). 
Ele recorre a Teubner para esclarecer que, de fato, por se tratar de sistema funcional autopoiético, "mesmo as mais poderosas pressões só serão levadas em conta a partir da forma como aparecem nas 'telas' internas [do direito], onde se projetam as construções jurídicas da realidade (rechtlichen Wirklichkeitskonstruktionen)". Por outro lado, também com base em Teubner, o autor afirma que, embora o direito siga uma lógica própria de desenvolvimento, é a sua relação com seu ambiente, por meio do acoplamento estrutural, que possibilita a abertura desse sistema às grandes evoluções sociais que, por sua vez, modulam sua própria evolução (1997, apud TEUBNER, p. 64).

A referência à ideia de abertura aqui não é incidental. Com efeito, tanto o fechamento normativo quanto a abertura cognitiva do direito, já mencionados acima, são necessários para a compreensão dos benefícios advindos de acoplamentos estruturais, na medida em que refletem considerações essenciais para que o direito possa realizar devidamente sua função social.

Mais especificamente, se, por um lado, o direito tem de preservar a consistência em sua reprodução - por meio de seu fechamento -, por outro, ele tem - por meio de sua abertura - de viabilizar as mudanças necessárias para evitar sua estagnação, demonstrando certa adequação social (GUERRA FILHO, 1997). Desse modo, resta claro como as irritações e perturbações canalizadas por acoplamentos, ao proporcionar uma abertura do direito a seu ambiente, possibilitam que o sistema jurídico aprenda e transforme suas estruturas. É nesse mesmo sentido que o acoplamento estrutural entre o direito concorrencial e teoria econômica revela-se benéfico.

Luis Fernando Schuartz, além de reconhecer explicitamente a existência do acoplamento entre o direito concorrencial e a teoria econômica, tangencia também os aspectos positivos dessa relação. Nesse sentido, ele discorre sobre como uma reorientação metodológica do direito antitruste no Brasil, com o escopo de tornar-se mais técnica ${ }^{52}$, tem garantido "o 'acoplamento estrutural' entre o direito antitruste e a ciência econômica" e explica que através desse acoplamento "se abre uma via de mão dupla a conectar esses dois âmbitos, estimulando um fluxo intensivo de informações” (2007, p. 3).

Ora, é justamente esse fluxo intensivo de informações do direito concorrencial com seu ambiente que permite que esse ramo do direito, ao mesmo tempo em que

\footnotetext{
${ }^{52} \mathrm{O}$ fenômeno a que se refere Schuartz será tratado mais adiante, no presente trabalho.
} 
preserva sua unidade, se mantenha dinâmico. $\mathrm{O}$ acoplamento estrutural entre direito da concorrência e teoria econômica serve de canal através do qual esses sistemas podem aprender um com outro e, a partir disso, se transformar.

Os benefícios proporcionados pela relação do direito com outras disciplinas é também objeto de estudo de Marcus Faro de Castro. Embora não parta da teoria dos sistemas de Luhmann - e na realidade se mostre bastante crítico a essa teoria ou ao menos ao que identifica como desdobramentos dela ${ }^{53}$ - o autor diagnostica um problema no ensino jurídico e na atividade judicante no Brasil, cuja solução inclui o que ele chama de intercâmbio do direito com outras disciplinas. Sua teoria não se destina especificamente ao direito concorrencial. Não obstante, tanto o diagnóstico quanto os remédios propostos por Castro podem ser úteis à compreensão dos benefícios decorrentes da relação do direito

\footnotetext{
${ }^{53}$ Não se ignora a existência de uma aparente contradição em relacionar a análise de Faro de Castro à teoria de Luhmann, a qual é contundentemente criticada por Castro como uma das teorias que se encontram nas raízes do conceitualismo jurídico brasileiro. Não obstante, há que se fazer aqui uma leitura cautelosa de ambos autores. Luhmann de fato se propõe a elaborar uma teoria geral do conhecimento com pretensão de universalidade, de poder compreender todos os fenômenos sociais a partir de seus fundamentos (LUHMANN, 2010). Para tanto ele se utiliza de um pesado aparato conceitual marcado por um alto grau de abstração. Porém, não se pode olvidar que Luhmann parte de uma metodologia funcionalista em que a noção dinâmica de função é privilegiada em relação ao conceito de estrutura. Como, a partir desse ponto de partida epistemológico, o objeto é encarado sempre como um problema real a ser resolvido pelo sistema, ocorre uma substituição da ontologia clássica pelo construtivismo. Luhmann reitera que a forma a que ele se refere em sua teoria se baseia numa diferenciação e não numa noção rígida e predeterminada de forma. Nesse sentido, ele afirma que a "análise funcional utiliza o processo do relacionar com o fim de compreender o existente como contingente, e o distinto como comparável. Relaciona o dado, sejam estados ou acontecimentos, com pontos de vista do problema e intenta fazer compreensível e concebível que o problema possa ser solucionado desta forma ou de outra" (LUHMANN, 2007, p. 131-132). Há, portanto, o que ele mesmo chama de desontologização e funcionalização do objeto de estudo, o qual é voltado para a resolução de um problema real da sociedade (o sistema social mais abrangente). A própria sociedade, enquanto sistema, não se caracteriza por uma determinada essência (Wesen), nem tampouco por uma determinada moral, mas sim pela operação que produz e reproduz a sociedade: a comunicação (LUHAMNN, 2007, p.48). Logo, nota-se que a teoria de Luhmann, tal como concebida pelo próprio autor, não se pretende uma descrição estática da sociedade e de seus subsistemas (e.g., o direito, a economia e a política), mas sim um instrumento dinâmico para compreender estes últimos e resolver seus problemas. Nesse caso, os elementos concretos do que é objeto de análise são de extrema relevância. Por outro lado, também é necessário enfatizar que Faro de Castro não se opõe à existência e à aplicação de teorias, mas sim à redução dos problemas reais a análises estritamente teóricas, que desconsideram o contexto sobre o qual incide a teoria. A importância e utilidade de uma teoria jaz na sua capacidade de auxiliar na resolução de problemas reais. Assim, apesar de indicar que a teoria dos sistemas de Luhmann é um dos meios pelos quais os juristas acadêmicos buscam compensar contemporaneamente "a perda de sistema" do direito e de sustentar que os esforços dessa teoria não tendem a conduzir a metodologias que auxiliem no engajamento disciplinado dos juristas com os fatos concretos, Castro também observa que "[i]ndependentemente dos méritos ou deméritos que possam ser atribuídos a esforços de derivar das [teorias dos sistemas e da ação comunicativa] elaborações sobre o direito, especificamente no que se refere à apropriação da "teoria dos sistemas" para fins de aplicação do direito, pesa o ônus de se demonstrar que tal aplicação é capaz de proporcionar uma abordagem crítica dos fatos, afastando-se do conservadorismo (impossibilidade de contribuir para a efetiva reforma do direito) que caracteriza a sociologia positivista de um modo geral" (CASTRO, 2012, p. 212-213, grifo nosso). Verifica-se, portanto, que o autor em questão, especificamente em relação à teoria dos sistemas, não afirma que ela deva ser invariavelmente desprezada, mas considera que sua utilidade depende de sua capacidade crítica dos fatos, de analisar e resolver problemas concretos.
} 
antitruste com a teoria econômica. Diante disso, o presente trabalho explica, a seguir, o problema por ele identificado, bem como a abordagem por ele proposta para endereçar referido problema.

\subsubsection{A interação entre o direito e outras disciplinas como forma de combater o conceitualismo}

Em sua obra "Formas Jurídicas e Mudança Social: Interações entre o Direito, a Filosofia, a Política e a Economia", Faro de Castro faz uma crítica ao que considera "limitações associadas à visão mais convencional do direito. Tendo como foco principal o ensino jurídico brasileiro, o autor se volta contra o tratamento do direito como um conjunto de formas abstratas, autorreferenciadas e livres de contradições (2012).

Segundo ele, o direito, no País, é amplamente concebido como uma série de conceitos prontos, apresentados sob a forma de textos que, por sua vez, "parecem entendidos como meros descritores de coisas ('natureza jurídica' disso ou daquilo) e não como parte de procedimentos jurídicos em construção" (CASTRO, 2012, p.18). Para Castro, esses conceitos vazios, destituídos de qualquer abordagem prática dos fatos sobre os quais incidem, ao mesmo tempo em que são tomados como elementos definidores da validade do direito enquanto disciplina, são tidos como fonte de critérios para o exercício da autoridade dos magistrados, que buscariam, com tal abordagem, endossar uma pretensa neutralidade do poder judiciário (2012).

Além de dar exemplos de como esse conceitualismo se expressa no direito pátrio, o autor também explica qual a narrativa por trás da concepção do direito como conjunto de formas:

No ensino jurídico brasileiro, é comum a visão de que o direito, sendo existente desde os romanos, mas fundamentado na ética elaborada por filósofos gregos, corresponde a um conjunto de conceitos, tais como propriedade, família, herança e outros, com um valor normativo intrínseco e benfazejo. Nessa visão, o direito é caracterizado como um conjunto coerente de "formas" abstratas e autorreferenciadas que, tendo passado pela Codificação de Justiniano e pelos esforços de organização intelectual dos juristas medievais, foi sistematizado por juristas europeus nos séculos XVIII e XIX e, finalmente, positivado em bons códigos, que se tornaram leis de várias sociedades até hoje por serem meios de proteger e promover a liberdade do indivíduo contra arbitrariedades. (2012, Prefácio) 
Por seu turno, ao analisar as origens de fato da maneira pela qual o direito brasileiro é estudado e aplicado, Castro detecta a ampla influência exercida pela cultura jurídica "conceitualista" ${ }^{54}$ do direito europeu continental ${ }^{55}$, sobretudo pelo constitucionalismo advindo da Alemanha. Além disso, outras teorias com abordagens significativamente abstratas, como o que denomina de neoconstitucionalismo ${ }^{56}$, também estariam relacionadas ao fato de a doutrina, o ensino do direito e a própria atividade judicante brasileira comumente apresentarem o direito como um conjunto de conceitos fora de contexto, com formas fechadas e universalmente válidas.

\footnotetext{
${ }^{54}$ De fato, para Castro, o conceitualismo deita raízes na longa história do direito europeu continental. No entanto, ao invés de um desenvolvimento linear e coerente das formas jurídicas ao longo do tempo, o autor narra as disputas entre diferentes grupos, com projetos de poder distintos, com vistas a se apropriar da ideia do direito como uma força unívoca. Nesse embate, a abordagem do direito enquanto conjunto de formas abstratas e absolutas ganhou diversas roupagens, que tinham como característica comum o fechamento do direito a considerações a respeito dos próprios fatos sobre os quais as normas incidiam. De acordo com o autor, na idade média, a jurisprudentia romana, materializada na Codificação de Justiniano, passou a ser associada à "ideia de Roma", império que havia atingido uma extensão até então jamais vista. Ela (a jurisprudentia) foi, por isso, apropriada por grupos políticos diversos com projetos de poder distintos. No entanto, diferentemente da jurisprudentia romana, os projetos políticos desses grupos, buscaram enfaticamente fazer a ligação lógica das formas jurídicas com abstrações metafísicas. Estas últimas constituíam um resgate do elemento platônico, o qual se pretendia absoluto, verdadeiro e incontestável, possibilitando o desenvolvimento de conceitos metafísicos estáveis, aptos a construir "sistemas" jurídicos amplos e coerentes. As críticas e os desafios que ao longo da história se apresentaram à estruturação do direito com base em um "elemento platônico" não levaram à destruição desse último, mas sim à sua refundação sobre novas bases. É assim que, por exemplo, a Filosofia do Direito Natural despontou como principal alternativa ao direito romano medieval, sem abandonar os pressupostos desse último; que o positivismo jurídico, sob o argumento de conferir racionalidade, coerência cientifica e unidade ao direito, apresentou um sistema de formas coesas, com pretensões ontológicas (ideia de que as normas focalizadas pela jurisprudentia correspondem espontânea e organicamente à consciência do povo e de que o conjunto de relações sociais orgânicas são perfeitamente designadas pelos institutos jurídicos); e que a jurisprudência dos conceitos (Begriffsjurisprudenz) - fonte de inspiração do direito constitucional alemão - defendia a ideia de que a ordem social retratada pelo direito corresponderia a um sistema de instituições e normas "fechado", autônomo, completo e de que os conceitos jurídicos teriam realidade em si mesmos, sendo permanentemente válidos e levando inevitavelmente a uma decisão correta.

${ }^{55}$ É nesse ponto em que o autor se mostra altamente crítico da Teoria dos Sistemas de Luhmann, na qual reconhece um elevado grau de abstração e fixação de conceitos, mediante os quais os juristas convencionais buscariam conferir coerência interna a ideias cujas consequências se desconhece. Para Castro, teoria de Luhmann seria um propulsor da cultura conceitualista, na medida em que a coerência interna propiciada pela noção de sistema seria um construto puramente formal que conferiria "falsa aparência de legitimidade à doutrina autorreferenciada" (CASTRO, 2012, p. 219). No entanto, conforme indicado anteriormente, deve-se ressaltar que, mais do que uma crítica à Teoria dos Sistemas em si, Faro de Castro é crítico daquilo que identifica como um desdobramento dela, isto é, da redução do direito a formas abstratas, absolutamente desconectadas da realidade a que são aplicadas (vide nota de rodapé 53).

${ }^{56} \mathrm{Um}$ dos principais enfoques da crítica de Faro de Castro é o que chama de neoconstitucionalismo, vertente que, segundo ele, foca na utilização de técnicas como a ponderação de valores e na valorização metodológica dos princípios para solucionar conflitos. Castro explica que, segundo Dworkin - um dos maiores expoentes da corrente neoconstitucionalista -, a solução de questões controversas, com que se deparam os juízes ao decidir, deveria se dar por meio de princípios. Esses últimos deveriam ser logicamente concatenados pelo juiz - que disporia de poderes interpretativos excepcionais- com vistas a revelar a decisão correta. Desse modo, para Castro, da mesma forma que o direito burguês, o qual está na base do constitucionalismo alemão, Dowrkin busca fundamentar as respostas para problemas práticos da vida em sociedade em formas abstratas, consideradas como plenamente suficientes para oferecer soluções com um grau de certeza lógica e moral que as tornam intrinsecamente cogentes (CASTRO, 2012).
} 
Apesar de recorrente, o emprego da fundamentação teórica de grande generalidade para o enfrentamento de desafios de natureza prática - como são os problemas jurídicos - é, de acordo com o autor, problemático, na medida em que teorias e conceitos abstratos frequentemente revelam-se apoios intelectuais insuficientes ou inadequados para superação de conflitos concretos (CASTRO, 2012). É dizer, como “inúmeras dentre as questões tratadas por juristas muito dificilmente produzem consensos gerais construídos em torno de formas abstratas e definitivas" (CASTRO, 2012, p. 1819), tais conflitos resistem, em grande medida, a ser satisfatoriamente capturados sob conceitos formais preestabelecidos (CASTRO, 2012).

Isto não significa, naturalmente, que o autor se oponha à existência de teorias jurídicas, nem à utilização das mesmas, mas marca uma contraposição à maneira como essas teorias são, a seu ver, frequentemente aplicadas. Em outras palavras, sua crítica não se volta contra o emprego de teorias do direito, mas sim contra abordagens que circunscrevem o direito a considerações teóricas, a um conjunto de fórmulas genéricas que estariam aptas a resolver os problemas que lhes são colocados, sem ter de atentar para o contexto em que se inserem. Afinal, se as teorias derivam sua utilidade e relevância de sua capacidade de auxiliar na resolução de problemas práticos, não há que se considerar as teorias jurídicas autossuficientes ou mesmo primordiais em relação ao engajamento com os fatos que envolvem os problemas concretos.

Para Castro, os resultados negativos da abordagem conceitualista são de três tipos:

um descolamento entre o intelecto do jurista e a realidade social, que é muito mais complexa do que as categorias jurídicas são capazes de analisar; uma dificuldade para avaliar de maneira responsável e analiticamente apta as políticas públicas e seus impactos sobre a vida social, dando-lhes um significado jurídico útil; e também para atuar apenas no sentido de preservar a ordem posta, não para reformá-la. (2012, Prefácio, grifos nossos)

Nas democracias contemporâneas, a insuficiência de teorias ou conceitos abstratos para a resolução de problemas práticos se torna, segundo o autor, ainda mais aguda devido ao que ele identifica como a dupla natureza do papel do jurista. Por um lado, nesse contexto, cabe ao jurista "organizar seu discurso em torno de certas abstrações conceituais, de modo a evitar que alterações indesejadas sejam introduzidas na ordem social, tal como ela existe no presente" (CASTRO, 2012, p. 16). Por outro lado, Castro chama atenção para a necessidade de o jurista "agir, concomitantemente, no sentido de impulsionar ou validar mudanças de ordem (...) em aspectos cuja permanência seja 
percebida como inaceitável". Tratam-se, respectivamente, dos papéis negativo e positivo do jurista nas democracias contemporâneas (CASTRO, 2012, p. 16).

Vale notar que, ainda que Castro seja crítico à compreensão do direito através da Teoria dos Sistemas e não se utilize dos conceitos por ela desenvolvidos para elaborar sua teoria, os papéis do jurista, que ele identifica, remetem a um desafio de equilíbrio com que se depara o direito moderno, apontado por Luhmann, e já mencionado nesse trabalho. Mais especificamente, o papel negativo do jurista, em que ele se orienta para preservar a ordem, pode ser aproximado do desafio enfrentado pelo sistema jurídico de manter sua consistência. Já o papel positivo do jurista, de promover a mudança social, pode, por sua vez, ser identificado com o desafio do direito de manter uma adequação social. Por conseguinte, a "capacidade de agir profícua e simultaneamente nessas duas frentes - uma, que evita o declínio e a dissipação da ordem, e a outra, que previne seu enrijecimento e a permanência de males ou injustiças -" (CASTRO, 2012, p. 16), pode ser relacionada à característica do sistema jurídico funcional de ser, ao mesmo tempo, normativamente fechado e cognitivamente aberto.

Ora, nesse sentido, os problemas identificados por Faro de Castro - descolamento do ensino e da aplicação do direito em relação à realidade sobre a qual incidem e atuação eminentemente no sentido de manter a ordem e não de transformá-la - parecem estar relacionados a um problema na abertura do direito a seu ambiente, ao que lhe é externo. Não causa surpresa, portanto, que o remédio proposto por este autor se baseie em duas medidas que endereçam justamente essa questão:

\footnotetext{
importância (...) deve ser dada ao esforço de abertura do trabalho jurídico para, (i) o intercâmbio com as 'formas' de outras disciplinas, uma abertura, portanto, para a interdisciplinaridade; e (ii) o engajamento metodologicamente ordenado com os fatos (pesquisa empírica), para deles adquirir uma percepção crítica - o que pode ser feito também com ajuda da interdisciplinaridade (pesquisa empírica) ou, em especial, pelo estudo da aproximação judicial em relação à facticidade espelhada nas decisões dos tribunais.(2012, p. 221, grifos nossos)
}

Castro considera que tais medidas são úteis - senão necessárias - para que tanto o estudo do direito quanto sua aplicação sejam orientados "para o fim de vislumbrar melhor as relações entre as representações intelectuais de que os juristas lançam mão e outras que lhes são alternativas" (2012, p. 216). A maior abertura do trabalho jurídico aos fatos concretos que envolvem o problema analisado, bem como a contribuições oferecidas 
por outros ramos do conhecimento, propiciaria uma abordagem do direito de caráter menos conceitualista e mais pragmático (CASTRO, 2012).

Em outras palavras, tanto $\mathrm{o}$ engajamento com os fatos quanto a interdisciplinaridade são, segundo o autor, centrais para que se possa promover uma visão mais realista do direito. São abordagens que, de acordo com ele, permitem uma dupla abertura e, assim, evitam o aprisionamento da mente do jurista a conceitualismos pouco úteis para resolução de problemas reais (CASTRO, 2012).

Nos moldes do já mencionado, a tese de Marcus Faro de Castro não se destina ao direito concorrencial especificamente, mas sim ao ensino e aplicação do direito como um todo, no país. O que o autor descreve (ou o problema que diagnostica) é uma forma de conceber o direito e de colocá-lo em prática que, ainda que afete de maneira distinta os diferentes ramos do direito, reflete uma postura em relação ao direito como um todo. Dessa forma, embora seja possível argumentar que o direito da concorrência possui fontes e referências jurídicas mais diversas do que outros ramos do direito aos quais Castro atribui uma influência eminentemente conceitual e reificante, não estaria o direito concorrencial imune a uma abordagem desse tipo. A fórmula proposta por Castro para combater o conceitualismo jurídico - engajamento com os fatos e intercâmbio com outras disciplinas -, portanto, serve igualmente para o ramo do direito em comento. Se não para remediar um conceitualismo existente, para mitigar o risco de que ele venha a se instalar no direito concorrencial. Assim como se pode depreender da teoria de Luhmann, também a partir da teoria de Castro é possível concluir que a abertura do direito da concorrência para seu entorno - particularmente para outras disciplinas, como é o caso da teoria econômica - lhe possibilita aprender com este último e, com isso, se transformar. Para Castro, é dessa forma que o jurista exerce uma de suas funções, qual seja, o de viabilizar a mudança, orientando-se pela realidade.

\subsubsection{Benefícios da relação entre o direito e teoria econômica no controle antitruste: algumas conclusões}

Conforme se pode observar na presente seção, a histórica relação entre o direito concorrencial e a teoria econômica pode ser compreendida como um diálogo profícuo entre duas disciplinas que se diferenciam, mas que, ao mesmo tempo - por meio do que 
Luhmann chama de irritações e perturbações transmitidas por um acoplamento estrutural - servem de aprendizado uma a outra, possibilitando que elas se transformem.

Os acoplamentos estruturais constituem as "pontes" entre os sistemas sociais e seu ambiente, viabilizando o contato do sistema com o que lhes é externo e, assim, permitindo sua constante atualização. Sem tais acoplamentos, os sistemas autopoiéticos padeceriam de um isolamento, de um autismo, que minaria sua própria capacidade de desempenhar suas funções, na medida em que estas (funções) consistem na própria relação que os sistemas parciais entretêm com a sociedade. Nesse sentido, portanto, pode-se dizer que a relação entre o direito concorrencial e a teoria econômica, mais do que mera constatação fática, é benéfica e desejável a ambas disciplinas.

Os benefícios oriundos dessa relação, para o direito concorrencial brasileiro, são também ilustrados pela teoria de Faro de Castro. Tal disciplina, enquanto ramo do direito, estaria sujeita aos problemas que este autor identifica em relação à forma como o direito é estudado, ensinado e aplicado no Brasil. Afinal, ainda que o direito da concorrência brasileiro tenha outras influências para além de europeias, ele se insere num contexto mais amplo, que influi na maneira como ele é compreendido e aplicado. Dessa forma, a interdisciplinaridade entre o direito e a teoria econômica parece despontar como um dos meios de mitigar o risco de que o direito concorrencial seja reduzido ao que o autor identifica como uma abordagem conceitualista.

Mais especificamente, não distante do que se depreende da teoria de Luhmann, a interdisciplinaridade proposta por Castro constituiria uma abertura do direito (no caso, o direito concorrencial) às formas de outras disciplinas (no caso, a teoria econômica) que, ao oxigená-lo, evitariam que subsistisse uma lacuna entre as representações intelectuais do direito e a realidade sobre a qual ele incide. Em outras palavras, a interface em questão, associada a um engajamento com os fatos concretos da lide sob exame, incrementaria a capacidade analítica dos aplicadores do direito em relação às políticas públicas e ao impacto que o direito tem sobre a sociedade. O direito - inclusive o direito concorrencial -, nesse contexto, não se limitaria ao estudo e aplicação de formas prontas e abstratas, descoladas dos problemas reais, mas teria verdadeiro potencial de transformação social.

Não obstante esses benefícios que podem decorrer da relação entre o direito concorrencial e a teoria econômica, há que se atentar também para os limites dessa relação. A indistinção entre esses dois ramos, promovida pela ideia de que a defesa da 
concorrência deve se ater a ponderações de cunho estritamente econômico, já é objeto de amplo debate de especialistas na matéria. As limitações dos modelos econômicos e a contestação de sua neutralidade política são, talvez, os principais enfoques das críticas feitas à redução da defesa da concorrência a análises econômicas e ao consequente esvaziamento dos elementos jurídicos. A próxima seção apresenta sucintamente algumas dessas críticas e se volta para a importância das ponderações jurídicas no controle antitruste e da diferenciação entre direito concorrencial e teoria econômica.

\subsection{Limites da relação entre o direito e teoria econômica no controle antitruste}

\subsubsection{As limitações da teoria econômica}

A teoria econômica, nos moldes do já exposto, se relaciona com o direito da concorrência desde a origem do controle antitruste. Não obstante, o papel por ela desempenhado ganhou proeminência sobretudo com a Escola Neoclássica de Chicago que, com vistas a conferir maior objetividade à análise antitruste, pretendeu tornar a eficiência a única finalidade do controle em comento.

Conforme apresentado, de acordo com tal escola, o rigor técnico da teoria econômica seria um remédio contra a ambiguidade e maleabilidade de argumentos de outra natureza, os quais estariam, invariavelmente, revestidos de algum caráter político. A teoria econômica teria, nesse sentido, condição de conferir neutralidade à defesa da concorrência, despindo-a de qualquer juízo de valor. A soma desses fatores (rigor técnico e neutralidade política), por sua vez, é o que fez e ainda faz da teoria econômica da Escola Neoclássica de Chicago algo extremamente atraente e torna plausível o apelo de que a racionalidade jurídica - supostamente variável e incoerente - seja substituída pela transparência e previsibilidade do critério de eficiência econômica (FRAZÃO, 2014, p. $8)$.

Por outro lado, a despeito do extremismo de alguns defensores da escola em questão $^{57}$, as limitações da teoria econômica como instrumento de representação da

\footnotetext{
${ }^{57}$ Ver, nesse sentido, Devlin, 2010.
} 
realidade e como única fonte de informação da análise concorrencial são apontadas por diversos especialistas em controle antitruste.

Esse é o caso, por exemplo, de Richard Whish. Ao mesmo tempo em que reconhece que a análise de questões concorrenciais invariavelmente requer uma compreensão de conceitos econômicos, o autor observa que o modelo econômico da concorrência perfeita, no qual a análise antitruste se fia amplamente, nada mais é do que uma teoria e que as condições necessárias para a sua integral realização são extremamente difíceis de serem realizadas na prática. De acordo com ele, uma estrutura de mercado que satisfaça concomitantemente todas as condições do modelo econômico em questão número alto de ofertantes e consumidores; produtos homogêneos; ausência de assimetrias informacionais; livre fluxo de recursos de uma área da atividade econômica para outra; ausência de barreiras à entrada e à saída - é improvável, senão impossível (2005).

Para além da improbabilidade de serem preenchidas todas as condições estipuladas pela teoria econômica para que a concorrência perfeita reste caracterizada, Whish também ressalta que alguns desses pressupostos são, em si, bastante questionáveis. A título de exemplo, ele menciona a noção de que todos os agentes econômicos são racionais e que sempre tentam maximizar o lucro, a qual, ainda que tomada como um dos pontos de partida da teoria em questão, não necessariamente encontra respaldo na realidade (2005).

Em linha com isso, Salomão Filho considera que um dos maiores pontos de questionamento da teoria econômica que integra os fundamentos e fornece instrumentos para a aplicação do antitruste diz respeito à intrínseca assimetria de informação na quase totalidade dos mercados. Fazendo referência à Akerloff, Stiglitz e Spence, o autor afirma que a simetria de informação é princípio hoje sabidamente irreal e que a constatação desse fato exigiria uma reformulação total das bases sobre as quais se sedimenta a aplicação do controle antitruste atual - reformulação esta que passasse tanto pelas famosas definições de mercado amparadas em modelos de oferta e demanda que têm por base a informação completa, quanto por campos inteiros que Salomão Filho considera hoje descurados pela doutrina e jurisprudência concorrencial (SALOMÃO FILHO, 2009).

Frazão, igualmente, ao discorrer sobre as limitações das abordagens exclusivamente econômicas ou consequencialistas na implementação da defesa da concorrência, sumariza uma série de aspectos polêmicos, que tornam bastante indagável 
a identificação satisfatória entre bem-estar do consumidor e alguns dos conceitos mais aceitos e utilizados de eficiência (2014).

Primeiramente, porque as condições de eficiência produtiva e alocativa - nesse último caso, especialmente a eficiência analisada pelo modelo de Kaldor-Hicks - podem ser alcanças em situações em que somente as empresas de fato ganham, restando a mera probabilidade de que os consumidores sejam compensados (FRAZÃO, 2014) ${ }^{58}$. Em segundo lugar - e em consonância com o já apontado acima -, porque os elementos da teoria da concorrência perfeita - como, por exemplo, a possibilidade de entrada tempestiva de concorrentes em um mercado, em virtude de aumento abusivo de preços se baseiam em modelos altamente idealizados. Dada a complexidade do mundo real, porém, tais expectativas podem demorar para se consumar, ou sequer vir a ocorrer. Outro aspecto apontado por Frazão, ao questionar a autossuficiência e completude da teoria econômica para o controle antitruste, é a dificuldade de se mensurar e quantificar o próprio norte das análises de eficiência: o bem-estar do consumidor (2014).

Em face de tais considerações, a autora apresenta forte objeção à ideia de que a eficiência possa servir como "um critério único, claro e coerente para orientar a política antitruste" (FRAZÃO, 2014, p. 11). Afinal, a dificuldade de mensuração dos elementos que compõem a análise de eficiências gera uma "indefinição que compromete o objetivo principal da teoria [neoclássica da Escola de Chicago], que seria o de conferir uma maior segurança e previsibilidade ao direito da concorrência” (FRAZÃO, 2014, p.12).

Para além da impossibilidade de a eficiência figurar como norte absolutamente objetivo da defesa da concorrência, o argumento, propagado teoria econômica da Escola de Chicago, de que a eficiência, como meta do controle antitruste, é totalmente destituída de ponderações de valor também é objeto de questionamento. Isso porque, nos moldes do já apresentado no presente trabalho, a política antitruste, ao longo de sua história, foi informada por diferentes objetivos, sendo a eficiência um deles e não menos relacionado com a conjuntura política e econômica vigente à época de sua ascensão.

Mais especificamente, a identificação da defesa da concorrência com o objetivo de eficiência invariavelmente envolve a opção por certos valores - seja o utilitarismo, o

\footnotetext{
${ }^{58}$ A autora em comento, nesse ponto, não apenas está em linha, como faz referência a Salomão Filho, que, ao tratar de concentrações entre agentes econômicos, pondera que a própria ideia de que a redução dos custos, decorrentes dos ganhos de eficiência, implique redução dos preços aplicados ao consumidor é mera presunção, já que não há garantia qualquer de que isso de fato venha a ocorrer (SALOMÃO FILHO, 2007).
} 
livre mercado, o bem-estar do consumidor $^{59}$ ou, mesmo, simplesmente, a própria eficiência $^{60}$. Mesmo porque, conforme explica Salomão Filho, se, por um lado, a eficiência como escopo afasta considerações sobre a forma de distribuição de riqueza, por outro, não se pode negar que ela converte a maximização da riqueza global em um valor em si. Nesse caso, “a sociedade ideal, eficiente, é aquela que atinge estado de equilíbrio em que a vantagem dos beneficiados é idêntica à perda dos onerados" (SALOMÃO FILHO, 2007, p. 31).

O ideal de eficiência, porém, ao revestir-se de uma suposta neutralidade, imbui nos outros eventuais objetivos da política antitruste um elemento de volatilidade e arbitrariedade, que fazem o objetivo de eficiência parecer a única opção plausível. Em outras palavras, a aventada imparcialidade revela-se um artifício útil para conferir à eficiência prevalência sobre outros valores a informar o controle antitruste.

A crítica dirigida à ideia de que a eficiência seria politicamente neutra faz mais, contudo, do que meramente identificar tal escopo com certos valores, assim evidenciando a falácia argumentativa em tela. Isto é, ela não apenas contesta a possibilidade de esvaziar a política antitruste de valores políticos, como também o próprio interesse em se proceder nesse sentido. Conforme observa Hovenkamp,

O argumento de que uma política particular possa ter transcendido a política é ao mesmo tempo atraente e perigosa. Sua atratividade reside no fato de que permite a criação de uma política pública estável que não se modificará a cada alteração na liderança política. (...) O perigo, por outro lado, é de que o argumento retire determinada política pública do processo político como um todo - o que significa, no caso de uma democracia, que ela é retirada do processo democrático. No limite, a teoria antitruste da Escola de Chicago pode

\footnotetext{
${ }^{59}$ Ao refletir sobre o argumento de que a identificação do controle antitruste com o objetivo de eficiência conferiria maior objetividade e imparcialidade a tal controle, é interessante considerar as ponderações de Frazão e de Salomão Filho a respeito do assunto. Conforme observa Frazão, ao mesmo tempo em que se apresentava a eficiência econômica como ideal despido de qualquer componente ético ou jurídico e, assim indiferente a qualquer problema relacionado à pobreza ou à distribuição de renda, houve uma preocupação por parte dos teóricos da Escola de Chicago de "apresentar a sua proposta de forma interessante e sedutora, identificando a eficiência econômica com uma abordagem nova e associada com o bem-estar do consumidor" (FRAZÃO, 2014, p.9). Salomão Filho, por seu turno, nota que o "principal mérito da Escola de Chicago e, sem dúvida, a principal razão da aceitação pelas Cortes de sua tese, está no fato de ter sido capaz de adaptar objetivos tão claramente de política econômica (como é a defesa da competitividade das empresas americanas) a uma teoria econômica aparentemente preocupada exclusivamente com a defesa do consumidor, e, portanto, de grande apelo teórico e até político ideológico" (SALOMÃO FILHO, 2007, p. 39). Verifica-se, portanto, que, a suposta neutralidade propagada por alguns dos ferrenhos defensores da Escola de Chicago é logicamente infirmada pela própria escola em questão, na medida em que estes buscam, através da identificação da eficiência com o bem-estar do consumidor, tornar sua tese mais palatável e atraente.

${ }^{60}$ Como bem observa Salomão Filho, “[p]ara os teóricos neoclássicos, esse valor [de eficiência] se sobrepõe e elimina qualquer outro objetivo que possa ter o direito concorrencial, inclusive a própria existência da concorrência" (SALOMÃO FILHO, 2007, p. 23)
} 
até permitir ao aplicador da política antitruste ignorar o intuito do Congresso em elaborar as leis ${ }^{61}(2005, \text { p. } 68 \text {, tradução livre })^{62}$.

Ora, se a identificação da defesa da concorrência com o objetivo de eficiência envolve a opção por certos valores, não há porque excluir essa escolha do debate político. Como bem nota Salomão Filho, a suposta neutralidade econômica e exatidão matemática são artifícios que não podem obscurecer o fato de que a orientação do controle antitruste para a eficiência - como maximização de riqueza no sentido paretiano - protege interesses, pois, caso contrário, sequer existiria. Afinal, "não existe regra vazia sem uma pretensão ou um interesse a proteger" (SALOMÃO FILHO, 2007, pp. 31-32). Tais interesses, uma vez que existentes, devem ser tratados da maneira mais transparente possível e ser inseridos no debate político, como qualquer outro objetivo que poderia vir a informar a orientação da defesa da concorrência.

Em linha com isso está o raciocínio de Pitofsky. Após constatar que os argumentos econômicos desfrutam, atualmente, de extrema influência sobre o controle antitruste, o autor ressalta que é fundamental explicar a razão pela qual tais argumentos, embora de importância central, não devem ser considerados exclusivamente. Para ele, a eliminação de valores políticos da defesa da concorrência consiste na construção de uma má história, de uma má política e de um mau direito ${ }^{63}$ (1979, pp. 1051-1052). Diferentes pontos compõem a justificativa dessa afirmação.

Sucintamente, pode-se dizer que, para o autor, em primeiro lugar, a história legislativa das normas que disciplinam o controle antitruste exige que outras ponderações, que não de cunho econômico, sejam feitas quando da efetivação do referido controle ${ }^{64}$. Em segundo lugar, ao mesmo tempo em que uma abordagem estritamente calcada na teoria econômica reflete uma visão otimista irrealista da certeza que poderia ser gerada pela análise econômica, o autor pondera que não há por quê sustentar que a introdução de

\footnotetext{
${ }^{61}$ Cabe destacar que o presente trabalho não adentrará uma discussão sobre os méritos e deméritos de regimes democráticos e de seus atributos. Aqui, a preferência por regimes democráticos e pelos processos que os caracterizam é pressuposto, ou seja, ponto de partida.

${ }^{62}$ Nos termos do autor: "the claim that a particular policy has managed to transcend politics is both appealing and dangerous. Its appeal is that it permits the creation of a stable policy that will not change with every change in political leadership. (...) The danger, on the other hand, is that the assertion takes a particular policy out of the political process all together - which means, in the case of a democracy, that it is taken out of the democratic process. At the extreme, Chicago School antitrust policy may even permit the antitrust policy maker to ignore Congressional intent".

${ }^{63}$ Nos termos do próprio autor: "It is bad history, bad policy, and bad law to exclude certain political values in interpreting the antitrust laws".

${ }^{64} \mathrm{O}$ autor refere-se, aqui, naturalmente, a história legislativa da defesa da concorrência norte-americana. Não obstante, conforme apresentado na primeira parte do presente trabalho, as normas antitruste norteamericanas serviram e ainda servem de referência mundialmente.
} 
fatores não econômicos consistiria em interferência indevida no controle antitruste. Mesmo que a inserção desses outros fatores tivesse como resultado inconveniente uma perda de previsibilidade e a introdução de certa instabilidade no universo supostamente ordenado e coeso da análise microeconômica, Pitofsky assevera que uma política de defesa da concorrência que deixasse de levar em consideração questões ou valores políticos seria insensível aos desígnios dos representantes da população à qual se aplicam as normas concorrenciais e, assim, descolada do consenso político sobre o qual se amparam estas mesmas normas (1979).

Resta, portanto, claro que se a opção por um ou outro objetivo antitruste inevitavelmente envolve a escolha por (ou ao menos a prevalência de) um ou outro valor, não há motivo para excluir tais ponderações do debate público, do processo democrático. Nesse sentido, Pitofsky nota que, ao discutir política antitruste, é importante levar em consideração, por exemplo: i) o receio de que uma excessiva concentração de poder econômico fomente pressões antidemocráticas; ii) o desejo de potencializar a livre iniciativa; iii) e a preocupação de que uma economia dominada por alguns poucos conglomerados gigantes torne impossível que atuação do estado se dê da maneira menos intrusiva na esfera econômica $(1979)^{65}$. Também nesse sentido, alguns autores questionam se a própria ideia de concorrência perfeita é válida para todos os setores indistintamente ou se não seria, por exemplo, inapropriado expor a força de trabalho à disciplina integral do processo concorrencial, em face de outros valores que mereçam ser resguardados (WHISH, 2005) ${ }^{66}$.

Tais considerações denotam que se, por um lado, a eficiência econômica não dispõe da objetividade e neutralidade política propagandeadas pela Escola de Chicago, tornando evidente a insuficiência da teoria econômica para informar o controle antitruste,

\footnotetext{
${ }^{65}$ Nos termos do próprio autor: "by 'political values, 'I mean, first, a fear that excessive concentration of economic power will breed antidemocratic political pressures, and second, a desire to enhance individual and business freedom by reducing the range within which private discretion by a few in the economic sphere controls the welfare of all. A third and overriding political concern is that if the free-market sector of the economy is allowed to develop under antitrust rules that are blind to all but economic concerns, the likely result will be an economy so dominated by a few corporate giants that it will be impossible for the state not to play a more intrusive role in economic affairs".

${ }^{66}$ Segundo Whish, esse é o ponto demonstrado pelo julgamento da Corte Europeia de Justiça em Albania International vs. Stichining Begrifspensionenfonds Textielindustrie que concluiu que a barganha coletiva entre organizações representando empregados e empregadores não se encontra dentro do escopo do artigo 81 EC. Ainda de acordo com ele, embora que a Comissão Europeia tenha assumido uma linha mais rígida nos últimos anos, os sistemas de direito concorrencial frequentemente hesitam em determinar que os profissionais liberais "sujem suas mãos" com algo tão ofensivo como preços concorrenciais ou "advertising" (2005, p. 13).
} 
por outro, sequer é desejável excluir ponderação de valores do debate referente à defesa da concorrência.

As ponderações quanto à pertinência de a teoria econômica figurar como único critério a informar a análise antitruste não se circunscrevem à Escola de Chicago. Conforme já apontado anteriormente no presente trabalho, as teorias econômicas pósChicago, ao mesmo tempo em que não representam uma ruptura com a escola neoclássica em questão, inserem novas nuances na teoria econômica aplicada à defesa da concorrência, incrementando a ambiguidade e complexidade dessa última.

Esse incremento de ambiguidade e complexidade, por seu turno, denota, ele próprio, as dúbias implicações das conclusões que podem ser obtidas pelas teses econômicas e as limitações das condições teóricas sob as quais tais conclusões podem ser aplicadas (HAYER, 2005), uma vez que amparadas em estudos cujos resultados são aplicáveis somente a contextos específicos ${ }^{67}$ (CHRISTIANSEN, 2006). Afinal, se, por um lado, o novo ferramental analítico da teoria econômica - com técnicas quantitativas, análises econométricas e modelos de simulação mais avançados - se mostra mais sensível às sutilezas das situações fáticas analisadas, por outro, ele proporciona equilíbrios consideravelmente sensíveis a uma série de elementos cuja observação empírica é complicada. Como consequência, a obtenção de respostas conclusivas quanto aos efeitos de determinadas condutas se torna mais difícil (COOPER et. al, 2005).

As referências acima são apenas exemplificativas da miríade de ressalvas e críticas feitas à teoria econômica - inclusive ou talvez até mesmo sobretudo à teoria neoclássica -, as quais possuem diferentes teores e graus de profundidade. $\mathrm{O}$ amplo universo dessas críticas é ilustrado por Salomão Filho que, ao abordar as nuances das ressalvas feitas à teoria neoclássica, cita desde grupos que criticam o modelo por ela empregado, mas mantêm seus postulados, até grupos que ressaltam a importância, para a análise econômica, de elementos menos óbvios, como a ponderação de valores ${ }^{68}(2002$, pp. 3-4).

\footnotetext{
${ }^{67}$ É interessante a observação de Hovenkamp de que, a despeito do ganho em complexidade e riqueza das análises econômicas, os responsáveis por elaborar e aplicar a política antitruste são relativamente relutantes em aderir a essas teorias. Como resultado, a economia aplicada ao processo decisório antitruste é bastante convencional, ao passo que a teoria econômica "como um todo" é muito mais técnica, arrojada, especulativa, estilizada e na margem, muito mais controversa do que a economia normalmente aplicada pelo agente competente pela implementação da política antitruste (2005).

${ }^{68}$ Mais precisamente, Salomão Filho refere-se a três diferentes grupos críticos da teoria neoclássica. $\mathrm{O}$ primeiro deles, conhecido como teóricos das imperfeições de mercado, crítica o modelo, mas não os
} 
Tais críticas à capacidade das teorias econômicas de representar a realidade - ou, dito de outro modo, a identificação das limitações inerentes à teoria econômica, em suas diferentes vertentes - suscitam mesmo, em alguns casos, a dúvida de se um ideal inatingível de concorrência perfeita sequer deve ser perseguido e se não seria preferível buscar desenvolver um modelo alternativo, que explique como mercados imperfeitos funcionam ou deveriam funcionar ${ }^{69}$.

O presente trabalho, porém, não tem por objetivo infirmar a relevância da teoria econômica para a defesa da concorrência, uma vez que reconhece que ela fornece instrumentos extremamente úteis à análise antitruste. Conforme observa Whish, a despeito das várias ressalvas e críticas feitas à teoria econômica a embasar a defesa da concorrência, tal teoria possui, ainda assim, elementos suficientes para levar a uma forte decisão a seu favor $(2005)^{70}$. Nos moldes do que coloca Salomão Filho, o controle antitruste não pode prescindir de instrumentos analíticos tão poderosos, que nos permitem tomar conhecimento da fundamental realidade econômica (2003).

\footnotetext{
postulados nem os métodos da teoria. Ele não pode ser considerado uma divergência metodológica de fato, na medida em que não busca negar o mercado nem o método de análise que lhe é aplicado pela teoria neoclássica, mas apenas evitar ou eliminar as falhas de mercado que identifica. O segundo grupo tampouco nega os pressupostos e método neoclássicos, mas procura identificar novos campos de estudo de questões que impossibilitam o bom funcionamento do mercado. Ao mesmo tempo em que o método neoclássico é mantido, os estudos levados a cabo por essa vertente visam reduzir os custos de transação, de modo a permitir que as transações de mercado fluam melhor. O terceiro e último grupo consiste de economistas que trabalham, em sua maioria, individualmente, e - tendo se debruçado sobre questões relativas à pobreza e ao desenvolvimento econômico - procuram enfatizar a importância de valores para a teoria econômica. O autor chama especial atenção para o trabalho de A. Sen, o qual questiona a teoria da escolha social e, ao mesmo tempo em que põe em xeque a possibilidade de determinar a situação social ótima com base exclusivamente no aumento de riqueza total, defende que haja uma revisão ética do conceito de racionalidade econômica (SALOMÃO FILHO, 2002, pp. 3-4).

${ }^{69}$ Ao tratar das limitações das teorias econômicas, Whish exemplifica o tom dos questionamentos feitos à adoção de um modelo de concorrência perfeita, no qual se baseia amplamente a análise antitruste. Segundo ele, alguns teóricos asseveram que, diante da impossibilidade de se atingir todas as condições para que a concorrência perfeita se veja realizada, é pernicioso aspirar a uma segunda melhor opção, em que algo similar, mas ainda assim distinto, é alcançado. De acordo com tais teóricos, uma segunda melhor solução poderia, na realidade, acentuar a ineficiência alocativa e o bem-estar do consumidor, uma vez que a distorção de mercado inevitavelmente afeta a performance em outras partes da economia. Em situações, por exemplo, em que a concorrência é imperfeita e existe monopólio, atacar monopólios individuais vulneráveis, ao mesmo tempo em que se deixa outros intactos, poderia simplesmente exacerbar a ineficiência alocativa existente. Com base nesse posicionamento de que seria pernicioso utilizar uma teoria que retrata mal a realidade, tais críticos sugerem, segundo Whish, a elaboração de um modelo alternativo. Em particular, eles creem que seria necessário que se decidisse como monopolistas e empresas em posição dominante devem ser tratados e que se desenvolvesse uma teoria adequada para lidar com o oligopólio, um fenômeno de mercado comum e, portanto, muito mais concreto do que o ideal de concorrência perfeita (2005).

${ }^{70}$ A despeito de todas as críticas, segundo Whish, mercados competitivos parecem, de uma maneira geral, entregar resultados melhores do que os monopolísticos, demonstrando benefícios aos consumidores. De acordo com ele, a concorrência promove eficiência alocativa e produtiva; leva a preços mais baixos para os consumidores; implica em investimentos em inovação, com vistas a ganhar mercado e isso implica em melhores produtos; e aumenta as possibilidades de escolha do consumidor (2005).
} 
Por outro lado, é importante que essas limitações sejam de fato consideradas pelos aplicadores da defesa da concorrência, de modo a evitar que os modelos econômicos sejam empregados como verdades máximas, autossuficientes, impassíveis de serem revisitados ou relativizados diante de argumentos de outros tipos ou mesmo diante da ausência de correspondência entre esses modelos e a realidade fática. Afinal, ainda que as críticas apresentadas acima tenham ganhado novo impulso diante da crise econômica iniciada em $2008^{71}$, muitas vezes "a discussão sobre os fundamentos essenciais das teorias econômicas não ultrapassa os artigos acadêmicos de alguns economistas ou os manuais de microeconomia dos teóricos ligados a essas escolas críticas" (SALOMÃO FILHO, $2009,16)^{72}$.

O presente trabalho, porém, pretende mais do que meramente jogar luz sobre as limitações da teoria econômica e sobre a necessidade de que tais limitações sejam incorporadas na análise antitruste. Ele pretende chamar a atenção para o fato de que a insuficiência da teoria econômica para a defesa da concorrência não reside simplesmente nas limitações dessa teoria, mas também no fato, muitas vezes negligenciado, de que o controle antitruste é feito por meio da aplicação do direito concorrencial, o qual é orientado por códigos e programas próprios ao sistema jurídico. Assim como é objetável que se exclua valores políticos do processo de elaboração e de discussão da política

\footnotetext{
${ }^{71}$ Conforme nota Devlin, a crise econômica, que teve início no mercado imobiliário norte-americano, colocou em xeque uma série de princípios da teoria econômica. Segundo ele, o movimento desregulatório implementado em diversos setores da economia dos Estados Unidos estava calcado na noção de que as forças de mercado produzem resultados superiores aos produzidos pela intervenção governamental e partia do pressuposto de que a teoria da escolha racional retratava adequadamente o comportamento econômico levado a cabo no mundo real, de modo que tanto empresas quanto consumidores agiriam de acordo com seus melhores interesses. Com base nisso, essa teoria sugeria que mercados seriam capazes de se autocorrigir, distorções econômicas seriam efêmeras e o comportamento racional produziria os resultados desejáveis socialmente. Vale ressaltar que, não obstante tais ponderações, o próprio autor assevera que a crença de que a crise de crédito global deve fornecer uma nova orientação para a política antitruste é um raciocínio bastante obtuso. Para ele, as bases microeconômicas que informam o controle antitruste norteamericano permanecem inalteradas pelos acontecimentos relacionados à crise. A inabilidade da macroeconomia de se autocorrigir prontamente e sem intervenção do governo após a crise de 2008 não guardaria, nesse sentido, qualquer relação com a entrada em mercado monopolizados. Ela estaria, na realidade, relacionada com a necessidade de desalavancagem, com a existência de insegurança jurídica generalizada e com a falta de capacidade dos mercados se recuperaram autonomamente de pressões deflacionárias severas. Destarte, os fundamentos da defesa da concorrência deveriam permanecer intactos (2010).

${ }^{72}$ Especificamente no que tange ao direito econômico, Salomão Filho observa que "[os] teóricos da análise econômica do direito ou das linhas mais recentes de estudo institucional sobre 'direito e economia' (com pouquíssimas e honrosas exceções) sequer tentam abordar essas questões, seja pela imensa complexidade que traria seu translado para o direito seja porque solaparia as bases científicas da teoria econômica que vem sendo por eles aplicada." (2009, p. 16)
} 
concorrencial, também é inaceitável que se exclua o direito da aplicação das normas antitruste. É sobre esse ponto que o próximo item do presente trabalho se debruça.

\subsubsection{A elementaridade do direito para o controle antitruste}

O item anterior explorou brevemente a inadequação de se excluir valores políticos do debate democrático referente à política antitruste. Uma vez que não existe política pública ou elaboração de norma vazias, desprovidas de interesses ou valores a resguardar, não se pode eliminar do debate público certas questões sob o artificioso pretexto de que uma orientação neutra, objetiva e, consequentemente, superior estaria disponível.

Em linha com o que foi apresentado anteriormente, a política concorrencial não existe num vácuo: ela é expressão dos valores e objetivos da sociedade e se encontra suscetível a mudanças, como o pensamento político em geral (WHISH, 2005). Ainda que a eficiência - identificada com o bem-estar do consumidor - tenha hoje, de maneira geral, ascendência, a breve retrospectiva histórica feita acima demonstra que muitos outros objetivos de políticas pública já foram perseguidos, ao longo dos anos, em nome da defesa da concorrência. Alguns deles não estavam, de forma alguma, ancorados na noção de bem-estar do consumidor em sentido técnico (excedente do consumidor), ao passo que outros iam mesmo na contramão da busca por eficiência alocativa e produtiva (WHISH, 2005).

A opção, através de uma discussão transparente, por um ou outro objetivo ou valor - ou mesmo por mais de um objetivo ou valor - a ser resguardado reflete-se, por seu turno, no desenho da norma voltada a regular o tema em tela. Isto é, estes objetivos e valores debatidos no processo político democrático são incorporados às normas concorrenciais, de modo que o direito - mais especificamente, o direito de defesa da concorrência - possa salvaguardá-los. Logo, esvaziar as ponderações propriamente jurídicas da aplicação das normas antitruste significa, no limite, esvaziar o próprio debate público em que se amparam tais normas.

Ora, a atribuição de preponderância absoluta às premissas econômicas, tornandolhes aptas a indicar diretamente o sentido das regras jurídicas, sem que isso possa ser contestado com base em considerações valorativas e distributivas, equivale a reduzir o direito a uma mímica do mercado. O que se defende, nesse caso, é que o mesmo modelo 
teórico empregado para explicar as relações causais seja utilizado para determiná-las pois, "uma vez aceita a veracidade das relações causais, a aceitação dos pressupostos implica necessariamente concordância com os resultados" (SALOMÃO FILHO, 2007, p. 30-31). Em outras palavras, pretende-se que, mesmo em presença do Estado, a proteção da concorrência seja resumida à garantia do funcionamento da mão invisível Smithiana (SALOMÃO FILHO, 2007, p. 21). No entanto, tal postura denota um equívoco em relação ao próprio conceito de norma jurídica, na medida em que claramente ignora o momento valorativo tanto de sua criação quanto de sua aplicação, seja em matéria econômica ou não (SALOMÃO FILHO, 2007, p. 21).

Nos moldes do apresentado anteriormente, nas sociedades modernas, o direito, enquanto subsistema parcial funcional, desempenha uma função para a sociedade, se voltando contra um determinado problema ao qual os demais subsistemas não se atentam. Mais precisamente, o sistema jurídico, para reduzir a complexidade do ambiente, absorve a contingência do comportamento social por meio da congruente generalização das expectativas normativas. A formação e reprodução dessas expectativas comportamentais congruente e normativamente generalizadas refletem, por seu turno, a identificação de direitos, os quais a sociedade pretende proteger e que, se desrespeitados, suscitam uma reação social, exigindo conformidade. Em suma, o sistema jurídico se volta a proteção de direitos, de pretensões às quais - embora não sejam representações de uma realidade de valor, no sentido de identificação com uma verdade imutável - a sociedade atribui um valor, uma relevância, em resguardar.

A função desempenhada pelo direito lhe é própria e singular, não podendo ser intercambiada com ou terceirizada a nenhum outro sistema. Apenas para o sistema jurídico a proteção de direitos goza de prioridade em relação a todas as demais funções. Para tanto, isto é, para o desempenho de sua própria função, é necessário que o direito goze de autonomia em relação a seu ambiente, reproduzindo-se de maneira autorreferenciada, por meio de código binário e programas próprios. A autopoiese do sistema jurídico reflete sua capacidade de autodeterminar ou, dito de outro modo, de evitar que elementos externos lhe determinem, imiscuindo-se em seus processos, corrompendo seus códigos e programas e desvirtuando suas funções.

Em linha com isso, Mestmäcker nota que a aguçada interdisciplinaridade entre direito e teoria econômica no controle concorrencial apenas torna mais latente a necessidade de se explicitar e reafirmar a autonomia da função do direito em relação à 
seara econômica. De fato, o direito leva em consideração pressupostos econômicos, deles absorvendo importantes referências para suas normas. Não obstante, a seleção dessas referências, a determinação de como elas se relacionam a demais aspectos, o reconhecimento do ideal de livre mercado ou mesmo da necessidade de restringir esse último devem se dar através da elaboração e da interpretação de normas jurídicas. A defesa da concorrência invariavelmente lida com a inexorável tensão existente na relação entre a teoria econômica e direito concorrencial. Não se pode olvidar, porém, que a própria existência dessa tensão denota a diferenciação entre esses sistemas e as distintas funções que desempenham (1973).

Embora não se utilize dos conceitos desenvolvidos pela Teoria dos Sistemas, ao criticar a força da teoria neoclássica nos estudos sobre desenvolvimento econômico, Salomão Filho trata também da importância da diferenciação entre o direito, a economia e a teoria que rege esta última. Segundo o autor, enquanto a economia e a teoria econômica se pautam por resultados, o direito, o qual constitui a base da organização social, se funda em valores (2002).

Partindo dessa distinção, ele esclarece que atribuir importância a valores significa abandonar uma visão determinista do desenvolvimento - própria da teoria econômica -, em prol do reconhecimento da "relevância da discussão sobre as formas especificas, para cada sociedade, de autoconhecimento e autodefinição de suas instituições e dos valores mais apropriados para seu desenvolvimento econômico e social" (SALOMÃO FILHO, 2002 , p. 8$)^{73}$. Daí decorre, por sua vez, a necessidade de se diferenciar as esferas de conhecimento em questão (direito, economia e teoria econômica) e impedir que as normas jurídicas se tornem mero instrumento da economia ou da teoria que sobre ela versa.

No mesmo sentido, Frazão discorre sobre a imprescindibilidade de se garantir o elemento jurídico na aplicação do direito concorrencial, tendo em vista os importantes valores por ele salvaguardados. A partir de uma sucinta análise do Sherman Act em sua gênese e primeiras fases, semelhante à elaborada no presente trabalho, a autora pondera que a defesa da concorrência nos Estados Unidos se voltava, dentre outros, à proteção da

\footnotetext{
73 Nos termos do autor: "Therefore, to give importance to values does not mean to substitute the determinism of results of the economic theory by a determinism of pre-established values. It means to give importance to the discussion about the specific forms for each society of self-knowledge and self-definition of the institutions and values considered to be the most appropriate for its economic and social development."
} 
livre iniciativa, da autonomia, da diversidade e da possibilidade de competir em condições de igualdade com base no mérito.

No entanto, mais do que explicitar o desígnio do direito concorrencial norteamericano de proteger certos valores, a autora se volta a explorar como isso ocorreu no Brasil. Para tanto, ela aborda não apenas os fundamentos da criação do direito da concorrência no País, ponderando que o percurso histórico revela que a implementação desse ramo do direito "não foi vista como mero mecanismo de defesa de mercados, mas também como instrumento de preservação da sociedade e das próprias instituições democráticas" (2014, p. 7). A análise de Frazão é tanto mais valiosa porque se debruça sobre como a defesa da concorrência está atualmente estruturada no ordenamento jurídico brasileiro e como o direito antitruste, enquanto ramo do sistema jurídico (e aqui não se faz referência ao conceito de sistema de Luhmann), se relaciona com as demais normas desse sistema.

Mais especificamente, ela chama a atenção para o fato nada trivial de que a lei de defesa da concorrência brasileira - seja a Lei no 8.884 de 1994, que teve a maioria de seus dispositivos revogados, seja a Lei ${ }^{\circ} 12.529$ de 2011 - está inserida num ordenamento que tem como norma máxima a Constituição Federal de 1988 (FRAZÃO, 2014 p. 8). Tal norma, ao tratar da ordem econômica e financeira nacional, prevê uma série de princípios sobre os quais esta ordem se funda e os quais são, em larga medida, reproduzidos pelo texto legal das referidas normas infraconstitucionais (artigo 170 da CF/88). É nesse sentido que o artigo $1^{\circ}$ da Lei $n^{\circ} 12.529 / 11$ reitera que a ordem econômica - a qual a lei em comento busca resguardar de infrações - é orientada pelos ditames constitucionais de liberdade de iniciativa, livre concorrência, função social da propriedade, defesa dos consumidores e repressão ao abuso do poder econômico.

Mas a relação das normas infraconstitucionais com a Constituição não se circunscreve a alguns poucos dispositivos em que há menção expressa à livre concorrência. Conforme nota Frazão, “em um Estado democrático de direito, todas as relações de poder (...) devem ser exercidas em conformidade com os direitos fundamentais, as garantias institucionais e os demais princípios constitucionais" (2014, p. 15). É também por isso que o próprio dispositivo constitucional que estabelece que a "lei reprimirá o abuso do poder econômico que vise à dominação dos mercados, à eliminação da concorrência e ao aumento arbitrário dos lucros" (Artigo 173, $\S 4^{\circ}$ da $\mathrm{CF} / 88$ ) deve ser interpretado sistematicamente, tendo em vista a valorização do trabalho 
humano, a necessidade de assegurar a todos uma existência digna, conforme os ditames de justiça social, e em obediência aos princípios fundamentais (Artigos $1^{\circ}$ e $3^{\circ}$ da CF/88) e aos demais princípios listados nos incisos do artigo 170 .

Sabe-se dos desafios envolvidos na interpretação e ponderação de princípios os quais muitas vezes conflitam entre si. A textura aberta, a vagueza conceitual, a qual se atribui às normas jurídicas, vis a vis aos construtos teóricos que regem a teoria econômica, se torna ainda mais aguçada quando se trata de princípios jurídicos. Não é à toa que aqueles que defendem que se empregue estritamente o critério de eficiência, tal como elaborado pela teoria econômica neoclássica, como norte da defesa da concorrência, se referem à "maleabilidade ou ambiguidade de outros eventuais objetivos do controle antitruste" e fazem disso um argumento em prol do que defendem.

Porém, a dificuldade de interpretação e aplicação de regras e princípios jurídicos, "especialmente diante de uma sociedade e de uma economia cada vez mais complexas, não é razão para negligenciá-los, nem para a busca de soluções paliativas" (FRAZÃO, 2014, p. 18). Isso não apenas porque a teoria econômica não dispõe do grau de objetividade, precisão e neutralidade como alguns gostariam de fazer crer, mas sobretudo porque o sistema jurídico desempenha uma função própria na sociedade, de proteção de direitos, que não pode ser desempenhada por outras disciplinas (ou sistemas, no sentido luhmanniano) - com seus critérios (ou código e programas) de análise próprios - , sem que essa mesma função reste comprometida e o sistema jurídico, em si, enfraquecido.

Subordinar os critérios jurídicos aos critérios da teoria econômica - ou mesmo substituir os primeiros pelos segundos - pode também ser considerado uma negação da complexidade social e da necessidade de se definir com maior clareza as fronteiras de cada sistema. Afinal, conforme exposto, se cada sistema parcial funcional tem funções especializadas e não-intercambiáveis, assumir que o código e os programas de um sistema estão aptos a se sobrepor ao código e aos programas de outro sistema implica negar a necessidade de diferenciação desses sistemas com base em suas funções. Nos termos de Neves, ao não levar a sério "a complexidade social, desconsidera-se a própria diferenciação do direito como campo de ações e vivências dentro da sociedade, sustentando-se uma desdisferenciação (...) do direito [em relação a outros sistemas]" (2005, p. 2009). 
Também vale notar que a substituição, no direito da concorrência, do código e dos programas jurídicos pelo código e pelos programas da teoria econômica, suscita, segundo a teoria de Luhmann, um outro tipo de questão na sociedade atual. De acordo com o autor, ao mesmo tempo em que a autonomia dos sistemas funcionais exclui a possibilidade de que esses sistemas sejam regulados por meio de um supercódigo moral, essa mesma moral aceita e até mesmo moraliza esta condição (2007). A autonomia funcional dos sistemas é, para o autor, tão presente na sociedade moderna, que se tornou forma de autoconcepção dessa própria sociedade. Consequentemente, a corrupção do código binário e dos programas de um sistema pelos de outro é moralmente condenado pela sociedade moderna. Assim, da mesma forma que a corrupção na política, o doping no esporte ou a compra do amor são sabotagens de códigos identificadas por Luhmann como moralmente problemáticas para a sociedade (2007), o mesmo se aplicaria à substituição ou subordinação dos critérios jurídicos pelos da teoria econômica ${ }^{74}$.

Vale mais uma vez ressaltar que, ao reforçar a importância de se preservar o elemento jurídico do direito antitruste, impedindo que os construtos teóricos de outras searas substituam o raciocínio propriamente jurídico - ou, dito de outro modo, que os códigos e programas do direito sejam corrompidos ou mesmo substituídos pelos códigos e programas de outro sistema -, não se quer advogar pelo isolacionismo do direito.

Nos moldes do já apresentado no presente trabalho, a interdisciplinaridade (ou acoplamento estrutural entre sistemas) é positiva na medida em que permite o aprendizado recíproco entre diferentes esferas do saber, fornecendo-lhes "maior capacidade teórica e prática de enfrentar os problemas que se lhe apresentam e oferecer soluções mais apropriadas dos mesmos do que um modelo formalista, insensível à interdisciplinaridade" (NEVES, 2005, p. 212). Isso fortifica não apenas a adequação

\footnotetext{
${ }^{74}$ Nos termos do próprio autor: “[d]e los problemas más importantes que hoy día atraen la atención moralmente cargada son las prácticas con las cuales se sabotea la separación de los valores del códigoy con ello las codificaciones de los medios de comunicación simbólicamente generalizados. Esto es válido para cuando se quebranta la distinción legal/ilegal mediante la corrupción y para los fenómenos correspondientes en el campo de la política partidarista (2007, p. 316). Ele se volta a essa mesma questão em outro trecho: "[l] a autonomía de los sistemas funcionales - asegurada mediante codificaciones binarias propias - excluye la metarregulación por medio de un supercódigo moral, y la misma moral acepta e incluso re-moraliza esta condición. Porque ahora los sabotajes al código se vuelven problema moral-por ejemplo, la corrupción en la política y en el derecho, el dopaje en el deporte, la compra del amor, o las trampas con los datos de la investigación empírica. La amoralidad superior de los códigos funcionales se reconoce por la moral misma” (2007, p. 826).
} 
recíproca e uma certa cooperação num ambiente de conflituosidade disciplinar, mas também os respectivos campos do saber (NEVES, 2005).

É nesse sentido que a relação entre sistemas através de acoplamentos estruturais não deve ser confundida com a corrupção desses sistemas e, portanto, identificada como um problema a ser combatido. Pelo contrário, acoplamentos estruturais fortes impedem a corrupção e até fortalecem os sistemas entre os quais estabelecem uma ponte, na medida em que, em sua ausência, a relação entre esses sistemas necessariamente implicaria numa indiferenciação (LUHMANN, 2007). No entanto, para que subsista o acoplamento estrutural, os limites da interdisciplinaridade devem ser respeitados.

Não se trata de desafio trivial. Ao mesmo tempo em que resulta em uma série de benefícios, já expostos anteriormente, a operacionalização da interdisciplinaridade - de se encontrar o limiar em que a autonomia de cada disciplina, de cada sistema, permanece preservada - se revela uma dificuldade, sobretudo em face das tendências ao imperialismo disciplinar (NEVES, 2005). Embora não discorra especificamente sobre o direito concorrencial, Neves se volta às tendências desse tipo da teoria econômica em relação ao direito.

\begin{abstract}
[M]uitas vezes, implícita ou explicitamente, sob o rótulo da interdisciplinaridade, superestima-se o papel da análise econômica do direito e, sobretudo sob a fórmula aparentemente interdisciplinar "Law and Economics", pretende-se subordinar os critérios do direito a uma racionalidade puramente econômica. Nesse caso, pleiteia-se, por assim dizer, uma "economic jurisprudence" que desconhece qualquer racionalidade jurídica específica. Ou seja, não se trata de uma intermediação de racionalidade econômica e racionalidade jurídica, em favor de uma prática jurídica mais adequada economicamente, mas sim de um "imperialismo econômico" ou colonização econômica do direito (2005, p. 209).
\end{abstract}

A dificuldade de se proceder à interdisciplinaridade também pode ser compreendida a partir da análise de Teubner, o qual trata da tendência expansiva de alguns sistemas sociais com pretensão de universalidade. Tais sistemas têm por característica o fato de que, ao mesmo tempo em que possuem racionalidades claramente parciais, desenvolvidas individualmente e extremamente centradas em si mesmas, são "institucionalizados de fato em toda a sociedade e exigem aceitação universal" (TEUBNER, 2002, p. 94). 
Apesar de a economia não ser o único exemplo desse tipo de sistema $^{75} \mathrm{com}$ pretensão de universalidade, ele é, sem dúvida, segundo Teubner, um caso paradigmático, de modo que o autor se refere frequentemente a esse sistema para ilustrar como se manifestam as tendências expansivas de outros sistemas em relação ao direito. Nesse sentido, ele fala de um "movimento com a intenção de substituir o enfraquecido conceito de justiça pelo ideal de eficiência econômica do direito", por trás do qual jaz a ideia de que, se "[a]s leis internas do mercado e das organizações representam a natureza da sociedade moderna, (...) o direito deve refleti-las" (2002, p. 93).

Para influenciar os demais sistemas de maneira quase irresistível, exercendo sobre eles um firme controle, esses sistemas fortes se utilizam de artifícios que reforçam sua eficácia social ${ }^{76}$ e cuja compreensão pode auxiliar no entendimento sobre como a teoria econômica ganhou tamanha força em relação ao direito concorrencial, invadindo espaços propriamente jurídicos. Além de outros recursos, chama particularmente a atenção o fato de a economia, assim como os demais sistemas com pretensão de universalidade, elaborar uma teoria reflexiva - no caso, a teoria econômica - que pretende ser aceita como a única racionalidade universal, informando e controlando isoladamente as práticas.

Segundo Teubner, “a teoria econômica há muito tempo transpôs os limites de seu próprio domínio específico da economia e pretende ser a teoria válida da sociedade, que interpreta como uma gigantesca rede de análise de custo-benefício" (2002, p. 96). Na medida em que tal teoria - como qualquer teoria reflexiva - não se restringe a questões cognitivas, ela desenvolve "conceitos normativos excludentes para uma sociedade justa, que concorrem, como teoria (...) econômica da justiça, com uma justiça especificamente jurídica” (TEUBNER, 2002, p. 96). O emprego desse recurso (elaboração de uma teoria reflexiva com racionalidade universal) com vistas a obter eficácia social é ainda reforçado pelo fato de que a economia busca também imiscuir-se na teoria do direito com suas

\footnotetext{
${ }^{75} \mathrm{O}$ autor cita também a política, a ciência e tecnologia, o setor de saúde, a mídia, a moralidade do mundo da vida, além do próprio direito (TEUBNER, 2002, p. 94).

${ }^{76} \mathrm{O}$ autor refere-se a cinco características de eficácia social de que desfrutam os sistemas em questão. "Primeiro, sua base material consiste em práticas manifestas (...) Segundo, essas práticas também não são meras convenções (...) Ao contrário, os muitos deuses [sistemas sociais fortes] criaram muitas teologias, elaboraram abstrações sociais na forma de autoconceitos e teorias reflexivas que, por sua vez, controlam e racionalizam as práticas. (...) Terceiro, os muitos deuses até foram morar no santuário íntimo do direito, na própria teoria do direito. (...) Quarto, a própria prática jurídica não foi poupada do politeísmo. (...) Quinto, a mais poderosa arma, talvez, do novo politeísmo pode ser um a criação de um complexo de vários mecanismos independentes de produção de normas sociais que gerem normas jurídicas diretamente a partir dos vários subsistemas da sociedade" (TEUBNER, 2002, pp. 95-97)
} 
teorias econômicas sobre esse sistema, para, assim, apoderar-se do próprio aspecto legal desse sistema (TEUBNER, 2002).

Outro recurso, mencionado por Teubner, de que a economia faz uso para dominar o direito, é se apoderar da prática jurídica, induzindo a reflexão jurídica a simular as práticas econômicas, de modo a produzir normas economicamente adequadas (2002). A "economização" da prática jurídica, transformando profundamente os métodos de tomada de decisão judicial e o uso que fazem da doutrina jurídica, pode ser compreendida através da descrição que o autor faz dos processos empregados pelos sistemas com pretensão de universalidade - inclusive a economia - para se apoderar da prática jurídica:

\begin{abstract}
O direito representa a sociedade como se fosse um palco. A tomada de decisão jurídica é convidada a atuar na peça. A reflexão jurídica deve simular as práticas de outros subsistemas sociais de modo a produzir normas socialmente adequadas, isto é, normas que reflitam a lógica interna dos ambientes sociais do direito. (...) O direito faz mímica do mercado (TEUBNER, 2002, p. 96).
\end{abstract}

Em momento algum se pode depreender da análise de Teubner que a força da economia e da teoria que lhe serve de amparo dogmático figura como óbice para a interdisciplinaridade entre esse sistema e o direito. Não obstante, a tendência expansiva da economia, sua pretensão de universalidade e os poderosos recursos de que ela se utiliza para colonizar o direito chamam a atenção para a necessidade de se ser especialmente cauteloso no processo de operacionalização dessa relação. Em outras palavras, se o sistema econômico, eminentemente forte, não raro exerce pressões sobre os demais sistemas, comprometendo sua autonomia, a aplicação do direito concorrencial - no qual a interação entre direito e teoria econômica é intrínseca e constante - exige, portanto, que se esteja especialmente atento a isso, sob pena de se esvaziar o caráter jurídico do direito e, consequentemente, a função de proteção de direitos desempenhada por esse sistema.

Ao considerar os limites da interdisciplinaridade, cabe, por fim, voltar-se a tese de Faro de Castro. A despeito de defender, conforme anteriormente exposto, o intercâmbio com outras disciplinas como um dos remédios contra a abordagem conceitualista do direito, o autor não é insensível à necessidade de se ter cautela ao implementar a interdisciplinaridade.

Castro chama a atenção especificamente para o perigo a ser evitado de - sob o pretexto de promover o diálogo entre o direito e outros ramos do conhecimento simplesmente substituir formas antigas por novas. Isso porque, do mesmo modo como, ao longo da história, as críticas elaboradas a abordagens conceitualistas do direito 
desaguaram em resultados práticos semelhantes ao que fora criticado ${ }^{77}$, há o risco de as formas de outras disciplinas serem empregadas meramente como substitutos funcionalmente equivalentes às formas jurídicas correntes. Nesse caso, ao invés de proporcionar a abertura do direito à interdisciplinaridade, estar-se-ia tão somente reforçando, com formas de outras disciplinas, o que ele chama de neoformalismo jurídico brasileiro (CASTRO, 2012).

O autor alerta para o fato de, no direito pátrio contemporâneo, existir um movimento dos juristas no sentido de buscar compensar eventuais perdas de sistema - e aqui, vale lembrar, que ele critica a pretensão dos estudiosos e operadores do direito brasileiro de representar e aplicar esse último como um modelo fechado e autossuficiente - com algo que possa substituir o que foi perdido. Segundo Castro,

os juristas procuram alguma alternativa intelectual que auxilie a restaurar a imagem de que a análise jurídica deriva a sua credibilidade da robustez, coerência e completude do conjunto de 'formas' jurídicas, exibido como representação suficiente e objetiva do que a sociedade pode ser ou deve ser. (2012, p. 211)

A teoria microeconômica da escola neoclássica revela-se particularmente atraente nesse intuito. É nesse sentido que o autor chama a atenção para o prestígio de que desfruta atualmente a Análise Econômica do Direito, “estilo de análise jurídica desenvolvido com a intenção de adotar pressupostos microeconômicos para o processo de determinação das ‘formas' de jurisprudência” (CASTRO, 2012, p. 207).

Diante do cenário de conceitualismo reificante do ensino e da aplicação do direito brasileiro, é natural a conclusão do autor de que tanto a aplicação quanto o estudo do direito têm de ser orientados para "o fim de vislumbrar melhor as relações entre as representações intelectuais de que os juristas lançam mão e outras que lhes são alternativas" (CASTRO, 2012, p. 216). Há que se destacar, contudo, que, para além de promover a abertura do direito para outras disciplinas e para os fatos concretos, tornando o direito socialmente relevante, tal reorientação também se funda na necessidade de entender melhor a relação entre as referidas representações e outras que "na prática, passam frequentemente a ter precedência sobre argumentos jurídicos ou, ainda, a exercer

\footnotetext{
${ }^{77} \mathrm{Um}$ exemplo disso diz respeito às críticas que foram elaboradas ao conceitualismo arraigado no Direito Constitucional, tal como desenvolvido pelos alemães. De acordo com Faro de Castro, muitas delas desaguaram em resultados práticos semelhantes, substituindo as "formas" reificantes do direito burguês por outro equivalente funcional, ainda que com outros propósitos ou justificações (2012).
} 
um papel coordenador das reformas do direito" (CASTRO, 2012, p. 216). Isto é, uma melhor compreensão da interdisciplinaridade, para além de permitir que se desfrute melhor de seus benefícios, também é fundamental para identificar seus limites e quando esses são trespassados.

A despeito da relevância de se reconhecer e respeitar referidos limites, como diversas vezes se mencionou no presente trabalho, não é raro o diagnóstico de que, na aplicação do direito concorrencial, essas fronteiras têm sido frequentemente desrespeitadas. Trata-se de fenômeno relatado tanto em outras jurisdições ${ }^{78}$, quanto no direito brasileiro.

É nesse sentido, por exemplo, que Salomão Filho fala de uma inegável prevalência das teorias econômicas, em matéria antitruste, a ponto de os tratados jurídicos se contentarem com a mera reprodução dessas teorias. O autor se refere particularmente à popular Análise Econômica do Direito que - com sua cartilha própria de interpretação e conformação com a realidade econômica-social, a qual repousa sobre os pressupostos neoclássicos de aumento de riqueza total e eficiência - dá prevalência absoluta à fixação de objetivos econômicos, submetendo o direito a esses objetivos (2003).

A prevalência de argumentos econômicos em detrimento da racionalidade jurídica é também endereçada por Schuartz, o qual se refere à ocorrência de uma desconstitucionalização do direito concorrencial brasileiro. Segundo ele, não existe no "direito brasileiro exemplo análogo de colonização por uma teoria originalmente extrajurídica dos programas normativos substantivos utilizados enquanto premissas nas atividades de interpretação e aplicação do direito" (2008, p.11). A impermeabilização a argumentos substantivos de natureza constitucional e a desconstitucionalização metodológica relacionadas à essa colonização são reconhecidos, ainda, por Frazão, que, nos moldes do já apresentado acima, chama a atenção para a necessidade de se inverter esse fenômeno (FRAZÃO, 2014).

É com base tanto nesse diagnóstico, quanto em toda a explanação teórica feita até o presente momento, que a próxima parte desse trabalho se volta a analisar as decisões do Cade sobre um tema que compõe parte substancial e relevante de sua jurisprudência:

\footnotetext{
${ }^{78}$ A título de exemplo, menciona-se Pitofsky, segundo o qual: There probably has never been a period comparable to the last decade, however, when antitrust economists and lawyers have had such success in persuading the courts to adopt an exclusively economic approach to antitrust questions (1979, p. 1051).
} 
a elaboração ou aplicação (em alguns casos mesmo a imposição) de tabelas sugestiva de preços de honorários médicos (tabela médica). A hipótese aqui aventada, com base no apresentado acima, é de que, no que se refere à conduta em questão, os argumentos econômicos tenham sobrepujado os de cunho jurídico, convertendo o direito concorrencial em uma função da teoria econômica.

\subsubsection{Limites da relação entre o direito e teoria econômica no controle antitruste: algumas conclusões}

Uma vez apresentada i) a histórica relação entre a teoria econômica e o direito da concorrência, com suas variadas nuances; ii) a maneira pela qual esses sistemas podem se relacionar e ainda assim preservar sua autonomia; e iii) os benefícios que tendem a decorrer dessa relação, este item se voltou a explorar seus limites.

Para tanto, abordou-se, por um lado, as limitações da própria teoria econômica para servir de único critério a informar o controle antitruste. A partir de diferentes referenciais teóricos buscou-se explicar por que a teoria econômica não desfruta da objetividade matemática e neutralidade ideológica propagandeada por tantos defensores de que a eficiência econômica seja empregada como norte exclusivo da análise concorrencial.

Por outro lado, para além das limitações da própria teoria econômica, o item em questão se debruçou sobre as razões pelas quais deve-se atentar para a preservação do elemento jurídico nas análises antitruste. Mais uma vez, aqui, recorreu-se a diferentes autores para explorar a ideia de que o sistema jurídico tem como importante função a proteção de direitos e que não se pode substituir seus critérios de análise, sua racionalidade, sem comprometer, concomitantemente, o desempenho dessa função. Em face disso, a despeito dos benefícios decorrentes da interdisciplinaridade entre direito concorrencial e teoria econômica, é necessário que essa relação seja operacionalizada de maneira cautelosa, sobretudo considerando a tendência expansiva do sistema econômico. O afã em substituir formas jurídicas por econômicas - seja em nome de uma maior dinamicidade, seja em nome de uma pretensa maior objetividade - pode, inclusive, significar, simplesmente, a substituição do conceitualismo de uma disciplina pelo da de outra. 
Não obstante as ponderações acima, há o diagnóstico, por parte de certos autores, de que a teoria econômica figura, atualmente, no Brasil e em outras jurisdições, como o único critério considerado válido a orientar o direito antitruste. A próxima parte desse trabalho se dedica a verificar se tal avaliação procede no que diz respeito à jurisprudência do Cade sobre tabelas médicas. 


\section{Mapeamento e análise da jurisprudência do Cade sobre tabelas médicas}

A presente parte desse trabalho se volta à análise da jurisprudência do Cade sobre tabelas médicas, com vistas a compreender melhor os critérios utilizados pela autoridade antitruste brasileira no julgamento desses casos. O escopo, aqui, é buscar elucidar o teor da relação entre os argumentos de cunho econômico e aqueles de cunho jurídico invocados pela autoridade antitruste para tomar suas decisões, sem proceder, contudo, a uma análise substantiva, de mérito, desses argumentos.

Antes, porém, de proceder a análise da jurisprudência mapeada, será feita breve explanação sobre o mercado de saúde de suplementar no Brasil, discorrendo sobre seu histórico, a maneira como ele está regulado e organizado, quais são suas principais características e como isso impacta na regulação do setor, e, finalmente, abordando o panorama da saúde suplementar no País. Apenas então voltar-se-á à jurisprudência do Cade.

Quanto a esta última, vale notar que a seleção dos casos analisados no presente trabalho se baseou, primeiramente, na leitura das atas de sessão de julgamento (ordinárias, extraordinárias e reservadas) disponíveis no sítio eletrônico do Cade. A partir da leitura das 642 atas, que vão desde junho de 1996 até dezembro de 2014, foram selecionados todos os casos que envolvessem o setor de saúde ${ }^{79}$.

Dentre os casos selecionados, foram escolhidos aqueles em que estivesse em disputa a elaboração ou aplicação (em alguns mesmo a imposição) de tabelas sugestiva de preços de honorários médicos ${ }^{80}$ (tabela médica) ${ }^{81}$ e em que pelos menos uma das partes

\footnotetext{
${ }^{79}$ Nesse sentido, a referência a "sociedade médica", "cooperativa médica", "associação médica”, "sindicato médico", "seguradora de saúde", "operadora de plano de saúde”, "clínica”, "hospital” ou qualquer outra menção que remete ao setor de saúde foi fundamental para orientar a triagem dos processos.

${ }^{80}$ Foram excluídos os casos em que estava em disputa tão somente a elaboração, divulgação ou mesmo a imposição de tabela de serviços hospitalares e laboratoriais. Foi, portanto, excluída do escopo da pesquisa a grande maioria de casos envolvendo hospitais, laboratórios ou suas respectivas entidades representativas. Dentre os casos em que estava disputa a licitude de tabela de serviços hospitalares e laboratoriais, foram considerados apenas aqueles em que também estivesse em disputa a licitude da tabela de honorários médicos. Vale observar que, nessa hipótese, a tabela de honorários médicos era objeto de conduta levada por entidades representativas dos médicos (associações, sindicatos, conselhos, etc.), cooperativas ou clínicas.

${ }^{81}$ A aplicação ou imposição de tabela médica algumas vezes vinha acompanhada de outras espécies de conduta, como, por exemplo, a imposição de unimilitância. Esses casos envolvendo outras condutas além da aplicação ou imposição de tabela médica foram incluídos na análise jurisprudencial. Por outro lado, os casos que tratavam tão somente de outras condutas, foram excluídos.
} 
no polo passivo fosse entidade representativa de médicos, cooperativa ${ }^{82}$ ou clínica médica. Ademais, como o propósito do presente estudo é analisar a evolução das decisões do Cade sobre tabela médica considerando o posicionamento final do Tribunal em cada caso apreciado, foram selecionados apenas processos administrativos ou procedimentos recursais em que a autoridade foi chamada a rever questões de mérito ${ }^{83}$.

A partir da triagem acima foram selecionados 49 casos que mereceram estudo mais aprofundado. Para tanto, foram objeto de leitura o(s) relatório(s), votos e pareceres ${ }^{84}$ proferidos em cada caso. Cabe destacar, adicionalmente, que casos anteriores a 1996 período em que as atas de julgamento não estão disponíveis no referido sítio eletrônico e que, portanto, não foi incluído na pesquisa - mencionados nos votos analisados também podem ser considerados no presente estudo, ainda que não se encontrem contabilizados dentro da jurisprudência levantada.

\subsection{Mercado de saúde suplementar:}

\subsubsection{Breve histórico da saúde complementar no Brasil}

Além de consagrar a saúde como direito de todos e dever do Estado, a Constituição de 1988, ao autorizar a atuação do setor privado na assistência à saúde, consolidou a divisão de dois subsistemas que já existiam há décadas: o público e o privado.

O primeiro está organizado em torno do Sistema Único de Saúde (SUS), sistema de acesso universal e que tem por características o financiamento e a gestão pública. $\mathrm{O}$ subsistema privado, por sua vez, pode ser dividido em dois subsetores.

\footnotetext{
${ }^{82}$ Cabe ressaltar que, apesar de cooperativas médica não serem entidades representativas, mas sim sociedades de pessoas constituídas para prestar serviços aos associados, o volume de casos julgados pelo Cade envolvendo a aplicação ou imposição de tabela médica por essas entidades é expressivo. Desse modo, resta claro que uma análise adequada da jurisprudência da autoridade antitruste brasileira sobre tabela médica não pode prescindir da análise dos casos envolvendo cooperativas.

${ }^{83}$ Restaram excluídos, por exemplo, requerimentos e decisões referentes a averiguações preliminares (instauração, arquivamento, recursos, etc.).

${ }^{84}$ Os pareceres a que alguns votos fazem referência são emitidos pela Secretaria de Direito Econômico (SDE); pelas Secretaria de Acompanhamento Econômico (Seae); pela Procuradoria Especializada do Cade (Procade); pelo Ministério Público Federal (MPF) e pela Superintendência-Geral do Cade (SG).
} 
O subsetor liberal clássico consiste em serviços particulares prestados por profissionais de saúde de maneira autônoma, na medida em que eles próprios determinam as condições de tratamento e a forma de remuneração pelo seu serviço. Já no subsetor de saúde suplementar, os serviços são prestados por agentes privados, credenciados por operadoras de planos de saúde, que fazem a intermediação entre os prestadores de serviços e seus consumidores.

As origens da saúde suplementar remontam à década de 1940, com a criação das caixas de assistência, que "beneficiavam os empregados de algumas empresas por meio de empréstimos ou reembolso pela utilização de serviços de saúde externos à Previdência Social” (BRASIL, 2007, p. 22). Elas passam também pela década de 1950, em que surgiram sistemas assistenciais próprios a certas empresas estatais e a multinacionais instaladas no Brasil, os quais prestavam assistência médica direta a seus funcionários (BRASIL, 2007). No entanto, a década de 1960 é que foi de fato o marco das atividades de saúde suplementar no País. Ainda que se tratasse de um fenômeno circunscrito, as conquistas trabalhistas dessa época impulsionaram o oferecimento de serviços de saúde a funcionários de alguns setores - como estatais, bancos e certas instituições do governo federal (BRASIL, 2007), e abriram espaço para o posterior surgimento de planos voltados a classes sociais menos carentes (ALMEIDA, 2009).

No período militar a atuação de grupos privados na área de saúde expandiu-se substancialmente. De acordo com M. F. de Castro (2003), nas décadas de 1960 e 1970 verificou-se a "privatização da assistência médica promovida pelo Estado" (ELIAS, s.d, p. 94, apud CASTRO, 2003), a qual se institucionalizou mediante a captura da despesa social por grupos privados que se beneficiavam de um "mercado cativo" (ELIAS, s.d., p.94, apud CASTRO, 2003). Isso, somado à incapacidade do Estado de atender à demanda por assistência à saúde (PEREIRA, 2003) ${ }^{85}$, resultou no expressivo crescimento de planos e seguros de saúde na década de 1980.

Se, por um lado, a expansão do setor de saúde suplementar, nos anos de 1980, servia para suprir uma demanda a qual o Estado não conseguia responder, por outro, o crescimento acelerado do número e das modalidades de operadoras e da comercialização

\footnotetext{
${ }^{85}$ Apesar de o SUS representar um avanço nas políticas voltadas à inclusão da população e à universalização de serviços públicos, sua montagem lenta e precária acabou por ampliar a demanda por serviços de saúde suplementar (PEREIRA, 2003).
} 
de planos tornou evidente uma série de problemas característicos desse mercado (ALMEIDA, 2009). Segundo Pereira, durante a década de 1990, o mercado de planos de saúde foi marcado pelos seguintes problemas: restrição de cobertura e exclusão de procedimentos; cobranças indevidas para a admissão de pacientes; carências irregulares; falta de cobertura para doenças crônicas e degenerativas; insuficiência da abrangência geográfica do plano; descumprimento das normas de atendimento de urgência e emergência, dentre outros.

Apesar de o Código de Defesa do Consumidor (Lei $\mathrm{n}^{\circ}$ 8.078, de 11 de setembro de 1990) ter representado um incremento na proteção do usuário de assistência à saúde, os abusos praticados pelas operadoras levaram numerosas entidades representativas de usuários e de profissionais de saúde a pressionar pela regulamentação do setor de saúde suplementar (SALAZAR et al., 2003).

O governo, por seu turno, via a iniciativa regulatória como uma ação estratégica apta a redirecionar as tensões e reclamações dos consumidores em relação ao setor (PEREIRA, 2003).

Como consequência, foi editada, em 1998, a Lei $\mathrm{n}^{\circ}$ 9.656, a qual constitui o marco legal da regulação de saúde suplementar no Brasil. Esta lei, que dispõe sobre os planos e seguros privados de assistência à saúde, levou a importantes mudanças no setor, como veremos a seguir.

\subsubsection{A regulação da saúde suplementar}

Antes de tratarmos das características da saúde suplementar em geral e do impacto causado no setor por sua regulamentação, cabe discorrer suscintamente sobre como ele está organizado, quem são seus agentes e que tipo de serviços são nele prestados. Para tanto, as normas sobre o setor são bastante elucidativas. 


\subsubsection{Organização da saúde suplementar no Brasil}

De acordo com a Lei $n^{\circ}$ 9.656/98, planos privados de assistência à saúde são definidos como serviços de prestação continuada ou de cobertura de custos assistenciais a preço pré ou pós-estabelecido e por prazo indeterminado. Sua finalidade é garantir, sem limite financeiro, a assistência à saúde, por meio do acesso a profissionais ou serviços de saúde, visando a assistência médica, hospitalar e odontológica, que deve ser paga integral ou parcialmente às expensas da operadora contratada.

As operadoras de plano de assistência à saúde, por seu turno, são definidas pela mesma lei como as pessoas jurídicas constituídas sob a modalidade de sociedade civil ou comercial, cooperativa, ou entidade de autogestão, que operem planos de saúde. Essa definição é ainda desdobrada pela Resolução no 39 de 2000 da Agência Nacional de Saúde Suplementar (ANS) que determina que essas operadoras podem ser divididas em seis tipos, de acordo com a forma de acesso e o sistema de pagamento contratado: i) administradora $^{86}$; ii) cooperativa médica ou odontológica ${ }^{87}$; iii) $\operatorname{autogestão~}^{88}$; iv)

\footnotetext{
${ }^{86}$ Administradora: pessoa jurídica que propõe a contratação de plano coletivo na condição de estipulante (nesse caso a administradora assume o risco decorrente da inadimplência, com a vinculação de ativos garantidores para tanto) ou que presta serviços para pessoas jurídicas contratantes de planos privados coletivos de assistência à saúde. A Administradora tem também como características não possuir rede própria de serviços médico-hospitalares ou odontológicos, nem beneficiários próprios e poder ser vinculada a uma seguradora ou a outra modalidade de plano de saúde (ALMEIDA, 2009). Apesar de a RN no 39 da ANS estabelecer que a administradora é um tipo de operadora de plano de saúde, são as RNs no 195/09 e $\mathrm{n}^{\circ}$ 196/09 da ANS que a conceituam e dispõem sobre seu funcionamento.

${ }^{87}$ Cooperativa médica ou odontológica: sociedade de pessoas sem fins lucrativos, constituída conforme o disposto na Lei n 5.764 de 1971 (define a Política Nacional de Cooperativismo e institui o regime jurídico das sociedades cooperativas), que opera Planos Privados de Assistência à Saúde.

${ }^{88}$ Autogestão: entidade ou empresa que, por intermédio de seu departamento de recursos humanos ou órgão assemelhado, responsabiliza-se pela administração do plano privado de assistência à saúde de uma ou mais empresas. Esse plano deve ser destinado, exclusivamente, a oferecer cobertura aos empregados, pensionistas, aposentados e familiares dessa instituição ou, ainda, ser oferecido por associações de pessoas físicas ou jurídicas, fundações, sindicatos, entidades de classes profissionais ou assemelhado. Apesar de a $\mathrm{RN} \mathrm{n}^{\circ} 39$ da ANS estabelecer que a entidade de autogestão é um tipo de operadora de plano de saúde, é a $\mathrm{RN} \mathrm{n}^{\circ}$ 137/2006 da ANS que a conceitua e dispõe sobre seu funcionamento.
} 
filantrópica ${ }^{89}$; v) seguradora especializada em saúde ${ }^{90}$; ou vi) medicina ou odontologia de $\operatorname{grupo}^{91}$.

Uma vez esclarecido que o mercado de saúde suplementar no Brasil atualmente envolve um grupo de entidades - denominadas de operadoras de planos ou seguros privados de assistência à saúde (OPS) - autorizadas a administrar e comercializar serviços de planos ou seguro privados de assistência à saúde, cabe elucidar quais são os tipos de planos de saúde hoje existentes.

Os planos de saúde são classificados, pela $\mathrm{RN} \mathrm{n}^{\circ} 195$ da ANS, quanto às formas de contratação, em i) individual ou familiar; ii) coletivo empresarial; e iii) coletivo por adesão. Enquanto o primeiro oferece cobertura da atenção prestada para a livre adesão de beneficiários, pessoas naturais, com ou sem grupo familiar, os dois últimos são contratados por uma pessoa jurídica que mantém vínculo empregatício ou estatutário (no caso do plano coletivo empresarial), associativo ou sindical (no caso do plano coletivo por adesão).

Conforme explicita a jurisprudência do Conselho Administrativo de Defesa Econômica $^{92}$, apesar de ofertarem serviços de natureza significativamente semelhante (serviços de assistência à saúde), certas diferenças no formato e nas condições de contratação justificam o agrupamento dos planos individuais e coletivos em duas categorias distintas, as quais são aqui demarcadas para que se possa, mais adiante, compreender a atual situação do mercado de saúde suplementar no País.

\footnotetext{
${ }^{89}$ Filantrópica: entidade sem fins lucrativos que opera planos privados de assistência à saúde e que tenha obtido o certificado de entidade beneficente de assistência social (Ministério competente para emissão desse certificado varia conforme o caso), bem como a declaração de utilidade pública. Tal declaração obtida junto ao Ministério da Justiça ou aos respectivos órgãos dos estaduais e municipais.

${ }^{90}$ Seguradora especializada em saúde: sociedade que opera e comercializa seguro saúde, serviço que garante ao segurado a cobertura de riscos de assistência à saúde mediante a livre escolha do prestador de serviço e o respectivo reembolso. Sua autorização para operar planos de saúde está condicionada a sua constituição exclusivamente como seguradora especializada nesse ramo de seguro, estando vedada sua atuação em outros ramos e modalidades. A Lei $\mathrm{n}^{\circ}$ 10.185/01 dispõe sobre a especialização das sociedades seguradoras em planos privados de assistência à saúde e equipara essas entidades às demais modalidades de operadoras de saúde, bem como os planos por ela comercializados aos planos privados de assistência à saúde. Assim, também as seguradoras em questão devem se submeter às normas e fiscalização da ANS.

${ }^{91}$ Medicina ou odontologia de grupo: categoria subsidiaria de operadora, a qual abarca as empresas ou entidades que operam planos privados de assistência à saúde, excetuando-se aquelas classificadas nas modalidades apresentadas acima.
}

${ }^{92}$ Ver, nesse sentido, por exemplo, Ato de Concentração nº 08700.004065/2012-91. 
Dentre essas diferenças entre os planos individuais e coletivos, merecem destaque i) o fato de que os preços dos planos individuais são regulados pela ANS, enquanto que os preços dos planos coletivos podem ser reajustados livremente; ii) a diferença no rateio do risco da carteira de beneficiários dos planos individuais vis-à-vis a dos planos coletivos; e iii) a diferença nos prêmios pagos a esses planos. Esses dois últimos elementos, evidentemente, estão intimamente relacionados. Nos planos individuais o rateio do risco envolve um grupo bastante heterogêneo de pessoas, ao passo que, no plano coletivo, há maior homogeneidade dentro da população. Como consequência do risco superior envolvendo a carteira de contratos dos planos individuais, o preço pago pelos beneficiários desses planos é substancialmente superior ${ }^{93}$.

\subsubsection{Características da saúde suplementar e o impacto da regulamentação no setor}

De acordo com Arrow (1963), o mercado de cuidados médicos possui características específicas - derivadas em sua totalidade da incerteza que nele prevalece - que o impossibilitam de atingir as condições necessárias para alcançar um equilíbrio competitivo e um estado ótimo. Essas características, denominadas de falhas de mercado, são de dois tipos no caso em tela: a existência de externalidades e a assimetria de informações ${ }^{94}$.

A primeira delas ocorre quando um agente leva a cabo uma "ação que afeta outros diretamente, sem que tenha que pagar pelo resultado maléfico ou sem que seja remunerado pelo resultado benéfico" (STIGLITZ \& WALSH, 2003, p. 194). Já a segunda

\footnotetext{
93 A título de exemplo, registra-se que a instrução no Ato de Concentração no 08700.004065/2012-91 revelou, com base em dados das próprias operadoras, que um plano individual pode ser até $218 \%$ mais caro que o mesmo plano contratado via administradora (plano coletivo). De acordo com o parecer da Superintendência do Cade no caso em tela, isso ocorre tanto pela já mencionada diluição do risco quando a contratação ocorre de maneira coletiva, quanto pelo maior poder de barganha da administradora.

94 Arrow se refere às falhas de mercado em questão como "nonmarketability of the bearing of suitable risks" e "imperfect marketability of information". Segundo o autor, "the special structural characteristics of the medical-care market are largely attempts to overcome the lack of optimality due to the nonmarketability of the bearing of suitable risks and the imperfect marketability of information" (1963, $p$. 947). Nesse sentido, vale também esclarecer o que o autor entende por "marketability": "marketability refers to cases in which organization of the market does not require an individual to pay for costs that he imposes on others as the result of his actions or does not permit him to receive compensation for benefits he confers" (2003, 944).
} 
(assimetria de informações) se faz presente nas hipóteses em que um ou mais agentes de uma transação dispõem de mais ou melhores informações que o(s) outro(s).

No mercado de saúde suplementar, a externalidade se verifica no fato de que "os impactos de assistência à saúde vão além do bem-estar do indivíduo que obteve acesso a tratamento médico" (ALMEIDA, 2010, p. 4) ${ }^{95}$. A assimetria de informações, talvez a falha de mercado mais representativa do setor, se dá, por sua vez, entre seus três agentes relevantes: o consumidor, a operadora de plano de saúde e o prestador do serviço médico. Conforme explica Goldberg:

\begin{abstract}
Os provedores dos serviços segurados - os médicos - têm o incentivo a sobreofertar procedimentos a fim de aumentar a sua remuneração direta e elevar a certeza do diagnóstico às expensas do segurador. Já entre o paciente consumidor e o segurador, na presença de um plano sem restrições, os consumidores tendem a sobreutilizar o serviço, já que o custo marginal do produto demandado é zero (ANDRADE e MAIA, 2005). Para além do risco moral, um dos problemas clássicos - também decorrente de informação assimétrica - que afetam o setor é o da seleção adversa. Consumidores com maior propensão a doenças procuram o seguro e consumidores saudáveis deixam a carteira por considerarem o prêmio demasiadamente elevado. $\mathrm{O}$ resultado desse movimento é que as operadoras acabam selecionando um grupo de consumidores com risco mais elevado do que o da média observada na população (...). (2008, pp.330-331)
\end{abstract}

Nesse cenário, as operadoras tendem a buscar meios para limitar seus riscos, adotando práticas - como a limitação de cobertura ou a exclusão de doenças preexistentes - que podem acabar por "diminuir a efetividade da função seguro para a população coberta (...) [ou] por produzir uma segmentação da população em diferentes grupos de risco, com problemas, entre outros, de se assegurar o financiamento dos indivíduos mais pobres" (VIANNA, 2003, p. 337). De fato, muitas das queixas registradas antes da edição da Lei ${ }^{\circ}$ 9.656/98 dizem respeito a práticas das operadoras no sentido de mitigar seus riscos e custos.

Se, por um lado, as operadoras se deparam com um problema de risco moral e de seleção adversa, deve-se registrar, por outro lado, que esses agentes possuem melhores informações do que os consumidores sobre a qualidade do serviço ofertado, sobre seu

\footnotetext{
${ }^{95}$ Um exemplo clássico de externalidade existente no mercado de saúde, e empregado pelo próprio Arrow, é o caso da vacinação. Isso porque, os benefícios de vacinar um indivíduo excedem os benefícios gerados a esse indivíduo apenas, na medida em que assegura uma saúde melhor não apenas para ele, mas também para outros (1963).
} 
grau de solvência (segurança ou estabilidade financeira) e, consequentemente, sobre sua existência no futuro (SANTACRUZ, 2010, pp. 115-117).

Diante dessas falhas, a regulação do setor revela-se como uma alternativa voltada a garantir um serviço adequado e efetivo. Conforme observa Santacruz (2010):

\begin{abstract}
[O]s resultados dos mercados de assistência à saúde são indesejáveis do ponto de vista do bem-estar econômico e social, indicando a necessidade de presença de um agente regulador, especialmente por se tratar de um serviço no qual o funcionamento adequado e a necessidade de amplo acesso têm forte apelo político e social. (SANTACRUZ, 2010, 119)
\end{abstract}

A promulgação da Lei 9.656/98 e a criação da Agência Nacional de Saúde Suplementar (ANS) vieram a responder a essa demanda pela presença estatal no setor.

Em face do objetivo de reverter as distorções existentes nesse mercado e garantir os direitos dos usuários desse sistema, optou-se por regular fortemente o produto ofertado (assistência à saúde) e tentar assegurar que os investimentos no setor correspondessem àqueles socialmente desejáveis. Nesse sentido, Ragazzo e Machado notam que, para tornar mais equilibrada a relação entre beneficiários e operadoras e fazer com que essas últimas ficassem menos suscetíveis à falência, o marco regulatório buscou dar maior segurança aos consumidores quanto a seus direitos e aumentou as exigências econômicofinanceiras das operadoras (2011). Esses autores destacam que, entre as principais alterações promovidas pela referida lei, encontram-se:

(i) limitações quanto à regra de cálculo do prêmio, (ii) preços mínimos de comercialização do plano (medida que evita a admissão de riscos excessivos); (iii) a inclusão de uma cobertura obrigatória e limites máximos de carência, (iv) exigência de capital mínimo, (v) provisões de risco, (vi) provisão para eventos ocorridos e não avisados, e (vii) margem de solvência. (RAGAZZO \& MACHADO, 2011, p. 6).

É importante observar que, ao introduzir condições de entrada, de saída e de permanência das operadoras e ao exigir que um pacote mínimo de benefícios fosse ofertado - eliminando a possibilidade de as operadoras criarem "classes" de usuários com graus distintos de serviços de saúde cobertos - a Lei $\mathrm{n}^{\circ}$ 9.656/98 alterou profundamente a estrutura do risco das operadoras (VIANNA, 2003). É dizer, embora tais medidas tenham aumentado a proteção ao consumidor, elas tiveram como consequência a elevação de custos das operadoras. 
Ademais, ao mesmo tempo em que as operadoras se deparavam com a necessidade de reajustar preços para cobrir os novos custos, o fim do ganho inflacionário, com o lançamento do Plano Real, exigiu delas uma gestão mais profissional e eficiente (VIANNA, 2003).

O resultado dessas mudanças foi a saída do mercado de "empresas de menor porte, que não detinham ganhos de economias de escala, eram menos eficientes e com maiores riscos de insolvência" (ALMEIDA, 2010, p. 4). Logo, as transformações no setor aqui descritas tiveram como decorrência um aumento tanto do incentivo para a concentração quanto da dificuldade para a entrada de novas operadoras, características bastante úteis para compreender as tendências do setor de saúde suplementar, bem como sua situação atual.

\subsubsection{Panorama da saúde suplementar no Brasil}

Ao analisarmos a saúde suplementar no País, chama a atenção, em primeiro lugar, o já mencionado notável crescimento do setor. De acordo com dados da ANS, no primeiro trimestre de 2014, o setor de saúde suplementar contava com quase 51 milhões de beneficiários de planos de assistência médica ${ }^{96}$, registrando, portanto, um aumento de quase $63 \%$ em relação a dezembro de 2000 , quando o número de beneficiários desses planos era de pouco mais que 31 milhões. Nota-se também que, com exceção do período entre 2001 e 2002, o número de beneficiários aumentou em todos os períodos.

\begin{tabular}{|l|l|l|}
\hline Data & $\begin{array}{l}\text { Número de beneficiários de planos } \\
\text { de assistência médica }\end{array}$ & $\begin{array}{l}\text { Crescimento em relação ao } \\
\text { período anterior }\end{array}$ \\
\hline dez/00 & 31.161 .481 & -- \\
\hline dez/01 & 31.727 .080 & $1,8 \%$ \\
\hline dez/02 & 31.513 .309 & $-0,7 \%$ \\
\hline dez/03 & 32.074 .667 & $1,8 \%$ \\
\hline dez/04 & 33.840 .716 & $5,5 \%$ \\
\hline
\end{tabular}

96 Quantidade refere-se a beneficiário de planos de saúde com assistência médica, seja com ou sem odontologia. 


\begin{tabular}{|l|l|l|}
\hline dez/05 & 35.441 .349 & $4,7 \%$ \\
\hline dez/06 & 37.248 .388 & $5,1 \%$ \\
\hline dez/07 & 39.316 .313 & $5,6 \%$ \\
\hline dez/08 & 41.468 .019 & $5,5 \%$ \\
\hline dez/09 & 42.686 .816 & $2,9 \%$ \\
\hline dez/10 & 45.154 .355 & $5,8 \%$ \\
\hline dez/11 & 46.499 .273 & $3,0 \%$ \\
\hline dez/12 & 48.243 .789 & $3,8 \%$ \\
\hline dez/13 & 50.574 .517 & $4,8 \%$ \\
\hline mar/14 & 50.722 .522 & $0,3 \%$ \\
\hline
\end{tabular}

Fonte: ANS- Cadernos 2014

Por outro lado, o referido crescimento do setor não foi acompanhado por uma correspondente pulverização. Enquanto o mercado de planos privados de saúde tinha 1.305 operadoras ativas com beneficiários cadastrados ${ }^{97}$ em 2001, em 2014 esse número passou para 914 , o que representa uma queda de $30 \%$ do número de operadoras ${ }^{98}$ (ANS, 2014).

Ao tratarem das modificações estruturais no mercado de saúde que resultaram em maior concentração do setor, Ragazzo e Machado (2011) e apontam para o aumento nas operações de fusões e aquisições entre operadoras de planos de saúde, hospitais, laboratórios e outros. Segundo eles, apenas entre 2003 e 2010, foram notificadas 29 operações ao Sistema Brasileiro de Defesa da Concorrência (SBDC) envolvendo a aquisição de empresas do mesmo mercado e, em menor medida, a compra de empresas a montante ou a jusante da cadeia produtiva (RAGAZZO \& MACHADO, 2011).

Para além da queda do número de operadoras ocorrida pela saída de algumas empresas do mercado ou pelas aquisições e fusões entre empresas concorrentes ou verticalmente relacionadas, há que se notar também a tendência de concentração do setor em torno de operadoras com uma grande quantidade de beneficiários.

\footnotetext{
${ }^{97}$ Nesse dado excluem-se as operadoras exclusivamente odontológicas e sem beneficiários.

${ }^{98}$ Idem
} 
Em 1999 as operadoras com até 2.000 beneficiários detinham 52,1\% do total de beneficiários. Em 2008 verificou-se uma queda de mais de 50\% nessa fatia, na medida em que elas passaram a deter $21,7 \%$ dos beneficiários. No mesmo período, as operadoras com mais de 50.000 beneficiários, por sua vez, registraram um movimento no sentido contrário. Enquanto elas detinham apenas 3,6\% do total de beneficiários em 1999, esse percentual saltou para 13,6\% em 2008. Com base nesses dados Ragazzo \& Machado concluem que "(i) houve forte redução do número de pequenas operadoras e significativo aumento das operadoras de grande porte; [e que] (ii) a maior parte dos beneficiários se deslocou das pequenas para as operadoras "médias"' (2011, p. 206). Esses fenômenos notam os autores - não foram, porém, pontuais, mas contínuos, revelando uma tendência de crescimento, sobretudo no que tange às grandes operadoras (RAGAZZO \& MACHADO, 2011).

De fato, segundo a ANS, em março de 2014, mais de 25 milhões de beneficiários eram cobertos por apenas 25 operadoras. Isso significa que mais de $50 \%$ dos beneficiários de planos de assistência médica do País estavam sob cobertura de menos de 3\% das operadoras. Também merece destaque o fato de que apenas 3 operadoras $(0,3 \%$ do total de operadoras) detinham quase $20 \%$ do total de beneficiários.

\begin{tabular}{|l|l|l|l|}
\hline \multicolumn{4}{|l|}{ Assistência médica com ou sem odontologia } \\
\hline $\begin{array}{l}\text { Cobertura } \\
\text { assistencial do plano }\end{array}$ & $\begin{array}{l}\text { Percentual acumulado } \\
\text { de beneficiários }\end{array}$ & Operadoras & $\begin{array}{l}\text { Percentual acumulado } \\
\text { de operadoras }\end{array}$ \\
\hline 3.866 .971 & $7,60 \%$ & 1 & $0,1 \%$ \\
\hline 9.592 .249 & $18,90 \%$ & 3 & $0,3 \%$ \\
\hline 15.233 .253 & $30,00 \%$ & 7 & $0,8 \%$ \\
\hline 20.221 .360 & $39,90 \%$ & 13 & $1,4 \%$ \\
\hline 25.401 .807 & $50,10 \%$ & 25 & $2,7 \%$ \\
\hline 30.351 .176 & $59,80 \%$ & 47 & $5,2 \%$ \\
\hline 35.441 .285 & $69,90 \%$ & 89 & $9,8 \%$ \\
\hline 40.560 .510 & $80,00 \%$ & 161 & $17,7 \%$ \\
\hline 45.639 .134 & $90,00 \%$ & 298 & $32,7 \%$ \\
\hline
\end{tabular}




\begin{tabular}{|l|l|l|l|}
\hline 50.722 .522 & $100,00 \%$ & 912 & $100,0 \%$ \\
\hline
\end{tabular}

Fonte: ANS- Cadernos 2014

Verifica-se, assim, que os dados atuais sobre o setor de saúde suplementar no Brasil confirmam a tendência, identificada por diversos autores, de concentração no mercado em questão, com prevalência das grandes operadoras.

Para além da questão da concentração, outro aspecto importante para a compreensão desse setor diz respeito aos dados sobre as formas de contratação dos planos de saúde.

Se, nos últimos 10 anos, o número de beneficiários em planos de assistência médica cresceu em todos os tipos de contratação, o crescimento dos planos coletivos empresariais merece destaque. Enquanto o número de beneficiários em planos individuais cresceu cerca de 19,7\% - atingindo 10 milhões de vínculos - e o de planos coletivos por adesão cresceu 4,3\% - alcançando 6,7 milhões-, o de planos coletivos empresariais cresceu 106,6\% - chegando a 33,3 milhões de vínculos. Em uma década, esse tipo de contratação recebeu cerca de 17 milhões de novos vínculos e foi o único a apresentar variação positiva do número de beneficiários em todo o período.

Mais importante, porém, do que notar o crescimento isolado do plano coletivo empresarial, é notar que os planos coletivos conjuntamente (empresarial e por adesão) considerados registraram, em meados de 2014, mais de 40 milhões de beneficiários, o que significa 79,1\% do número total de beneficiários. Logo, os planos contratados via pessoas jurídicas detêm parcela predominante do total de planos de saúde contratados no País.

\subsubsection{Mercado de saúde suplementar: algumas conclusões}

A expansão da saúde suplementar no País, ao mesmo tempo em que serviu (e ainda serve) para suprir uma demanda a qual o Estado não conseguia responder, exigiu que se procedesse a regulamentação do setor, com vistas a mitigar uma série de problemas característicos desse mercado. 
Tal regulamentação, assim como as circunstâncias históricas, acabaram, por seu turno, por impor um perfil às operadoras de planos de saúde. Diante da nova estrutura de risco, verificou-se tanto um incentivo para concentrações, quanto uma dificuldade para a entrada de novas operadoras no mercado. Como consequência, o exponencial crescimento do setor, nos últimos quinze anos, não foi acompanhado por um correspondente aumento no número de operadoras. Pelo contrário, houve um decréscimo na quantidade de OPS, com, por um lado, a saída de agentes do mercado (sobretudo os pequenos), e, por outro, operações de concentração entre tantos outros agentes. Ademais, registrou-se uma concentração de consumidores em poucas operadoras, detentoras de parcela substancial do número de beneficiários nacionais.

Outra característica que merece destaque é que, embora o número de beneficiários em planos de assistência médica tenha crescido em todos os tipos de contratação na última década, o crescimento dos planos coletivos empresariais salta aos olhos. Isso, somado ao crescimento dos planos por adesão, fez com que os planos coletivos conjuntamente considerados detivessem, em 2014, quase $80 \%$ do número total de beneficiários de planos de saúde no Brasil, o que significa que os planos contratados via pessoas jurídicas detêm parcela predominante do total de planos de saúde contratados no País.

Quanto à concentração de mercado, importa ressaltar que ela não é algo necessariamente pernicioso. O próprio Guia para Análise Econômica de Atos de Concentração Horizontal da Secretaria de Acompanhamento Econômico (Seae) destaca que pode haver eficiências específicas a essas operações, como economias de escala e de escopo, a introdução de tecnologias mais produtivas, a apropriação de externalidades positivas ou a eliminação de externalidades negativas e a geração de um poder compensatório (SEAE, 2001).

No caso do setor de saúde suplementar, como vimos, a própria legislação gerou incentivos para que houvesse maior concentração no setor, criando empresas mais sólidas e menos suscetíveis a riscos. Por outro lado, não podemos olvidar que a maior concentração tende a trazer consigo maior poder de mercado que, exercido de forma abusiva, prejudica a livre concorrência ou mesmo outros valores e direitos amparados pelo ordenamento jurídico brasileiro e pelo próprio SBDC. Diante desse risco, a análise pelo SBDC deve ser especialmente aprofundada e cautelosa em casos envolvendo esse 
setor, e isso não apenas em sede de controle de concentrações, mas também em controle de condutas.

Por fim, o fato de quase $80 \%$ do número total de beneficiários no Brasil contratar planos de saúde via pessoas jurídicas (através de planos coletivos empresariais ou por adesão) denota uma tendência dominante no sentido de o consumidor não negociar a contratação desses serviços individualmente, o que, por sua vez, tende a lhe empoderar nessa transação. Também isso (além do alto nível de concentração entre operadoras de planos de saúde) é uma característica marcante do setor de saúde suplementar no Brasil, que pode vir a ser relevante quando da análise de um caso nesse ramo.

\subsection{Jurisprudência do Cade acerca de tabelas médicas}

A vasta jurisprudência do Cade sobre tabelas médicas não deixa dúvidas sobre a nítida orientação da autoridade no sentido de condenar essa conduta. Dentre os 49 casos analisados, 37 resultam na condenação das partes representadas ${ }^{99}$, o que significa que em pelo menos $75 \%$ dos $\operatorname{casos}^{100}$ a autoridade conclui pela ilicitude da conduta. O presente trabalho, porém, não visa a se debruçar sobre a correção dessas decisões, avaliando o mérito dos argumentos econômicos ou jurídicos empregados pelo Cade. Pretende-se, na realidade, deter-se em momento anterior e analisar como esses argumentos interagem entre si, qual peso lhes é conferido e se há, mesmo, eventualmente, prevalência de uma espécie de argumento sobre outro. Afinal, a parte anterior deste trabalho buscou explicar como o direito e a teoria econômica mantêm uma relação histórica no controle antitruste, sem que isso implique num comprometimento da autonomia dessas disciplinas (ou sistemas). Foi, então, abordado como a relação entre elas, ao mesmo tempo em que benéfica, possui limites que devem ser respeitados. A presente parte desse trabalho se volta, portanto, a verificar como isso se dá na prática

\footnotetext{
${ }^{99}$ Em um dos casos analisados (PA n $\left.{ }^{\circ} 08012.005135 / 05-57\right)$, a decisão da autoridade foi pelo arquivamento para uma das partes e pela condenação das demais.

${ }^{100}$ Diz-se, aqui, "pelo menos" porque, considerando que, dentre os casos analisados, 4 foram arquivados por vícios processuais e 1 encontra-se sobrestado em virtude do julgamento pendente de um mandado de segurança em outro processo, o índice de condenação poderia ser maior, fosse o mérito desses processos analisado.
} 


\subsubsection{Mapeamento e análise jurisprudencial}

Ao estudarmos a jurisprudência do Cade sobre tabela médica a partir de 1996, notamos que - nos moldes do afirmado pelo Conselheiro Eduardo Pontual, no Processo Administrativo $n^{\circ}$ 08012.006552/2005-17 - o Conselho tem sido incisivo na condenação de entidades representativas de prestadoras de serviços médicos pela imposição da tabela de honorários, seja pela mera existência da tabela, seja pelo emprego de meios coercitivos para impô-la. Mais do que isso, verifica-se que a autoridade sistematicamente condena esse tipo de tabela com base, fundamentalmente, num ideal de livre mercado, cujas forças de oferta e demanda seriam perfeitamente capazes de, por si só, estabelecer o equilíbrio desejado. São inúmeros os exemplos nesse sentido.

Essa ideia é claramente colocada, no Processo Administrativo $\mathrm{n}^{\circ}$ 08000.011520/94-40, pelo Conselheiro-relator Ruy Santacruz, para quem "[d]e fato, o preço justo é, por definição, aquele que surge como resultante das forças de mercado, isto é, das condições da oferta e da demanda. Não existe preço justo se fixado por uma das partes". Incorporando em seu voto decisões anteriormente proferidas sobre o tema, o relator reforça ainda essa posição ao dispor que a "adoção dessas tabelas é, em princípio, prejudicial à concorrência, porquanto elimina os mecanismos normais de formação de preços no mercado, de acordo com as regras da oferta e da procura"101 e que "não há dúvida de que a elaboração [delas] só pode ter o objetivo de obstar a atuação dos mecanismos de mercado para a formação de preço, ou seja, prejudicar a concorrência"102.

A defesa de que tabelas sugestivas de preços de honorários médicos seriam inadmissíveis na medida em que deturpariam o bom funcionamento do livre mercado é ainda explicitamente reiterada em outros votos ${ }^{103}$. No Processo Administrativo $\mathrm{n}^{\mathrm{o}}$ 08012.021738/96-92, por exemplo, após asseverar que a representada teria atuado de modo a subverter os mecanismos de livre formação de preços dos serviços médicos de anestesiologia, o Conselheiro Fernando de Oliveira Marques enfatiza:

\footnotetext{
101 Trata-se de trecho extraído do voto do Conselheiro Carlos Eduardo Viera de Carvalho, no PA n ${ }^{\circ}$ 62/92.

102 Trata-se de trecho extraído do voto da Conselheira Neide Terezinha Mallard, no PA no 53/92:

${ }^{103}$ Ver nesse sentido, ainda: PA n ${ }^{\circ}$ 158/94; PA no 173/94; PA n ${ }^{\circ}$ 174/94; PA n ${ }^{\circ}$ 08000.027395/95-80; PA $n^{\circ}$ 011518/94-06; PA n ${ }^{\circ} 08012.006397 / 97-02$; e PA n ${ }^{\circ} 08000.021976 / 1997-51$.
} 
[A] liberdade de mercado é princípio vital protegido pela legislação antitruste tanto do consumidor, quanto do ofertante, em arbitrar seu preço, disputando as preferências do consumidor. O equilíbrio entre essas duas forças se dá de forma natural e qualquer tentativa de imposição artificial de preços é causa de mal-estar econômico." (grifo nosso)

Nos Processos Administrativos $\mathrm{n}^{\mathrm{o}} \quad 08012.008060 / 2004-85$ e $\mathrm{n}^{\circ}$ 08012.005194/2001-00, o Ministro Villas Bôas Cueva apresenta argumento no mesmo sentido, ao constatar que o tabelamento prejudica o jogo de mercado, no qual os preços são livremente estabelecidos. De acordo com ele, o ideal competitivo estaria comprometido pelo fato de, através das tabelas, os preços dos serviços serem estabelecidos uniformemente, e não caso a caso. Do mesmo modo, o Conselheiro Eduardo Pontual, no Processo Administrativo no 08012.006552/2005-17, nota que a liberdade de mercado e livre negociação restariam prejudicadas, uma vez que o preço do serviço não estava sendo determinado no embate das forças de mercado, pelos mecanismos naturais de formação de preços.

Ao explicar como os efeitos perniciosos da distorção das forças de oferta e demanda se dariam concretamente nos casos de tabelas de honorários médicos, o Conselho comumente recorre à ideia de que a uniformidade gerada pela tabela não respeitaria as diferenças de custo enfrentadas pelos ofertantes, nem refletiria as diferenças na qualidade do produto ofertado.

Mais especificamente, a tabela comprometeria o equilíbrio natural gerado pelos mecanismos normais de formação de preço, na medida em que impediria que cada agente (médico) negociasse individualmente com o adquirente de seu serviço a que preço e condições este deveria ser prestado. Isso teria como resultado, por um lado, a supressão da possibilidade de escolha do consumidor com base no preço, uma vez que os preços estariam todos artificialmente uniformizados. Por outro, impediria que as operadoras negociassem com cada profissional tendo por base as particularidades deste.

A ideia de que a tabela médica suprimiria a possibilidade de diferenciação do serviço com base em sua qualidade foi expressa no Processo Administrativo no 156/94, no qual a Conselheira Lucia Helena Salgado transcreveu manifestação de Neide Mallard no PA n ${ }^{\circ}$ 61/93:

[M]édicos distinguem-se pela especialidade, notoriedade, experiência, atividade acadêmica, participação em congressos e seminários. A tabela 
médica, pela uniformização de preço, termina por igualar os desiguais e colocar no mesmo nível os bons e maus profissionais. (grifo nosso)

Em linha com esse entendimento, o Conselheiro Ruy Santacruz, no já mencionado PA no 08000.011520/94-40, incorporou os argumentos do Conselheiro Carlos Eduardo Viera de Carvalho no PA n ${ }^{\circ}$ 62/92:

De fato, é mesmo de se inferir que tais tabelas não terão trazido qualquer benefício aos usuários dos serviços, inibidos que são de exercer livremente sua escolha, em um mercado não competitivo, em que os preços são artificialmente idênticos; também preços tabelados tampouco beneficiam as entidades contratantes dos serviços, que não conseguem negociar, individualmente, preços, prazos e condições de pagamento. ${ }^{104}$ (grifos nossos)

Em suma, as decisões do Cade - predominantemente pela condenação de tabelas de honorários médicos - se fundam amplamente na noção de que as tabelas em questão distorceriam as forças que regulam o livre mercado. No caso, isso ocorreria através da supressão das peculiaridades de cada contrato que de outro modo existiriam e que com a tabela seriam tolhidas, uma vez que haveria impedimentos a que cada agente negociasse individualmente seus preços de acordo com seus custos e méritos.

Para além da defesa do ideal de livre mercado - amparado na argumentação de que as forças de oferta e demanda teriam condições de estabelecer naturalmente preços que não fossem uniformes, respeitando as particularidades dos prestadores de serviço -, outro argumento com bastante força nesses casos refere-se à análise de eficiências. No PA n ${ }^{\circ}$ 08012.007042/2001-33, por exemplo, o Conselheiro Schuartz afirma que

\begin{abstract}
Ante uma conduta de barganha coletiva de honorários por parte de um grupo de médicos, a questão jurídica relevante (...) é: A conduta é parte constitutiva de uma estratégia eficiente e mais ampla de integração de serviços e compartilhamento de riscos? Se não o for, deve ser - e provavelmente será - considerada uma violação da legislação antitruste e, enquanto tal, proibida
\end{abstract}

Em linha com isso é também a argumentação do Conselheiro Cueva e Pontual. O primeiro argumenta que, mesmo que se estiver diante de poder de oligopsônio das operadoras de planos de saúde, apenas a eficiência pode figurar como justificativa para conduta de tabelamento (Processo Administrativo $\mathrm{n}^{\circ}$ 08012.008060/2004-85). O

\footnotetext{
${ }^{104}$ Ver também, nesse sentido: PA no 158/94; PA no 173/94; PA no 174/94; PA nº 08000.010318/94-73; PA $n^{\circ}$ 011518/94-06; PA n 08012.021738/96-92; PA n 08000.027395/95-80; e PA n ${ }^{\circ} 08012.008477 / 2004-$ 48, no qual o Conselheiro Marcio de Oliveira toma como evidência do prejuízo da conduta a uniformização de preços imposta pelas entidades de classe, a qual falseia a concorrência.
} 
Conselheiro Pontual, por seu turno, além de afirmar que a eficiência é o valor orientador do direito da concorrência (Processo Administrativo no 08012.006552/2005-17) e esclarecer que são os "movimentos normais de acomodação no mercado que possibilitam maior eficiência alocativa", defende que a própria "legalidade depende de uma análise de custo benefício social sob a lei da concorrência" (Processo Administrativo $\mathrm{n}^{\circ}$ 08012.008477/2004-48).

A centralidade da eficiência como critério de análise de legalidade sob o ponto de vista do direito antitruste se torna particularmente evidente no debate sobre a licitude das tabelas adotadas por cooperativas ou clínicas médicas. Pode-se dizer que esse debate tem sua centelha em uma decisão de 2001, na qual o relator Arinos de Mello Franco Neto chama a atenção para o fato de que não havia indícios de que tivesse havido conduta concertada entre a clínica representada e seus concorrentes e, portanto, não haveria que se falar em conduta colusiva:

\footnotetext{
"Como já é conhecido pela jurisprudência do Cade sobre o assunto, o uso por vários participantes do mercado de tabela comum de preços pode configurar ilícito concorrencial quando configura exercício coordenado de poder de mercado (...), pela sua função de instrumento de coordenação das políticas de preços praticadas por concorrentes. (...) Em nenhum momento se alega no processo a presença de conduta concertada de preços referenciados à tabela da $\mathrm{AMB}$ no mercado relevante (...) Desse modo, o exame do enquadramento da conduta nos incisos referidos requer somente a verificação das condições para exercício individual de poder de mercado, o qual, por sua vez, não pode ter nenhuma relação causal com o uso da tabela." (grifos nossos)
}

A decisão do Conselho nesse caso, pelo arquivamento do processo com base no argumento acima relatado, apesar de estar então isolada, antevê uma discussão que ganha corpo apenas em 2005, com o PA nº 08012.003664/2001-92. Mais especificamente, é neste último que é aprofundado o argumento, até então subliminar, de que uma clínica ou uma cooperativa constitui um só agente, de modo que não caberia tomar a atuação de seus membros por uma conduta concertada. O debate em torno da adequação de se considerar a adoção de tabelas de preços pelas cooperativas médicas uma conduta colusiva ou indutora à colusão passa, a partir daí, a ter nítidos contornos. O voto da Conselheira Elizabeth Querido Farina é ilustrativo disso:

[D] eve-se fazer duas distinções no presente caso: i) a distinção entre os conceitos de concorrente e cooperado e ii) a distinção entre preço por serviço e sugestão de preços a concorrentes. A Lei no 8.884/94 veda a adoção de conduta comercial uniforme ou concertada entre concorrentes. A competição se dá entre agentes, que podem ser indivíduos ou 
organizações, mas não entre indivíduos da mesma organização. Logo, os médicos, enquanto cooperados da COOPANEST, não concorrem entre si, mas sim cooperam entre si na atividade cooperativa. Uma vez que a legislação não proíbe cooperativas, a atividade dos médicos como cooperados não é ilícita do ponto de vista concorrencial. (grifos nossos)

Nota-se, portanto, o entendimento (de ao menos de parte do Conselho) no sentido de que, nesses casos envolvendo cooperativas, não haveria conduta uniforme entre concorrentes, mas tão somente convenção de um preço a ser cobrado pelo prestador de serviços (a própria cooperativa). Nestes termos, o Conselheiro Roberto Castellanos Pfeiffer afirma:

[A] COOPANEST, no momento em que contrata, fixa o preço de seus serviços, como qualquer outra sociedade que irá vender seu produto, sendo que o contratante tem a liberdade para acordar ou não. A cláusula em questão trata nada mais nada menos do que o preço dos serviços que ela propõe a [sic.] prestar. ${ }^{105}$ (grifo nosso)

No mesmo sentido é o argumento do Conselheiro Luiz Carlos Delorme Prado:

\begin{abstract}
A tabela de preços a que se refere a conduta analisada consta dos contratos de prestação de serviços firmados entre COOPANEST- CE e os planos de saúde. Ora, o preço é elemento essencial para a formação deste contrato. A tabela apenas fixa o preço de tais contratos. Seria impossível a formulação de tais contratos sem que conste uma fixação de preços. Note-se que é a COOPERATIVA que firma o contrato e recebe o pagamento pelos serviços. ${ }^{106}$ (grifos nossos)
\end{abstract}

Dentro dessa análise, torna-se essencial o argumento de que não caberia perquirir se a adoção de tabela constituiria conduta concertada entre concorrentes, mas sim se haveria abuso de poder de mercado pela representada. Isto é, o fato de a tabela ser impositiva ou meramente sugestiva passa a ser de extrema importância. A existência de cláusulas de exclusividade que obrigassem os médicos a prestarem serviço unicamente à cooperativa ou a ameaça de descredenciamento e de instauração de processos disciplinares contra médicos que prestassem serviços a outras empresas seriam evidências de que a cooperativa estaria agindo de forma abusiva. Por outro lado, na ausência de coerções que impedissem os profissionais de contratar com concorrentes da cooperativa, o que subsistiria é a liberdade dos médicos de escolher com quem contratar:

A não existência da referida cláusula de exclusividade permite aos médicos negociarem livremente junto aos planos de saúde a sua remuneração. Se existe preferência, por parte dos médicos, de negociar e prestar seus serviços por

\footnotetext{
${ }^{105}$ Trecho do voto do Conselheiro Roberto Castellanos Pfeiffer no PA n ${ }^{\circ}$ 08012.003664/2001-92.

106 Trecho do voto do Conselheiro Luiz Carlos Delorme Prado no PA nº 08012.003664/2001-92.
} 
meio da Cooperativa, essa opção é legítima e pertence à esfera privada da liberdade de contratar ${ }^{107}$. (grifos nossos)

Da mesma forma, na medida em que deixava de ser, segundo esses argumentos, uma indução à conduta coordenada entre concorrentes, ou mesmo a conduta coordenada em si, e passava a ser mera fixação de preço por um agente no mercado, a adoção de uma tabela de preços tornava-se uma opção privada da cooperativa.

\begin{abstract}
Denota-se no caso em tela uma verdadeira relação privada entre COOPANEST-CE e as sociedades prestadoras de plano e seguros de saúde, uma relação contratual entre duas pessoas jurídicas, com personalidade e capacidade para contratarem, e não uma conduta por parte da primeira visando impor aos seus associados uma fixação de preços de seus honorários $^{108}$. (grifo nosso)
\end{abstract}

No entanto, essa linha argumentativa - de que cooperativas (e, pela lógica, clínicas também) não poderiam ser acusadas de conduta coordenada pela mera utilização de tabela médica para referenciar seus contratos - sofre grande abalo diante do questionamento da personalidade jurídica das cooperativas e clínicas com base no critério de eficiência.

A lógica apresentada pelo Conselheiro Villas Bôas Cueva é especialmente ilustrativa de como esse argumento é construído. Além de endossar o entendimento prevalecente na jurisprudência do Cade de que tabelas médicas seriam ilícitas pela distorção dos mecanismos naturais do mercado de formação de preço, ele se volta especificamente contra o argumento de que não se poderia atribuir conduta colusiva a uma cooperativa pelo fato de ela adotar tabela médica como base para remuneração de seus médicos cooperados.

[N]ão se admite o argumento de que a personalidade jurídica da cooperativa representada afastaria, por si só, a colusão. Como se sabe, a concessão de personalidades distintas para a sociedade e seus sócios é mera técnica de separação de patrimônios e não pode ser considerada finalidade em si mesma. Há que se analisar sempre a efetiva existência, a natureza, o funcionamento real das sociedades. Do contrário, estar-se-ia aceitando que as sociedades que se prestassem a encobrir situações de fato diferentes das disciplinadas em seus estatutos sociais, em claro abuso de forma. $\mathbf{O}$ direito da concorrência, contudo, deve privilegiar a substância sobre a forma e perquirir pelos reais efeitos de determinadas condutas, sem se deixar iludir por simulacros destinados a contornar a finalidade protetiva das normas jurídicas. ${ }^{109}$

\footnotetext{
107 Trecho do voto do Conselheiro Luiz Carlos Delorme Prado no PA n 08012.003664/2001-92.

108 Trecho do voto do Conselheiro Roberto Castellanos Pfeiffer no PA nº 08012.003664/2001-92.

109 Trecho do voto proferido pelo Conselheiro Ricardo Villas Bôas Cueva nos PA n ${ }^{\circ}$ 08000.005351/199742.
} 
Para o Conselheiro, portanto, é necessário atentar para se as cooperativas não estariam meramente representando um meio de legalizar um acordo para fixação de preços e condutas, ao invés de desempenhar outras funções justificáveis e legítimas. Logo, sob esse ponto de vista, a questão passa a ser como determinar quando uma cooperativa é constituída e está operando de acordo com seus fins legítimos e quando se trata de mero embuste jurídico para acobertar conduta colusiva.

Se, por um lado, revela-se absolutamente pertinente indagar sobre os aspectos fáticos dos casos apreciados, por outro, chama a atenção o critério proposto pelo Conselheiro para conduzir a análise desses fatos. A ideia de que as cooperativas ou clínicas poderiam constituir simulacros destinados a contornar a finalidade protetiva das normas jurídicas e de que a personalidade jurídica não deve servir de proteção para esse tipo de comportamento remete à noção de que poderia ocorrer o desvio de finalidade dessas entidades, com vistas a burlar o direito concorrencial. Para se compreender quais casos poderiam constituir um uso indevido ou anormal da personalidade jurídica, há que se ter um parâmetro, isto é, há que se identificar qual seria, afinal, "a efetiva natureza, o real funcionamento dessas sociedades".

Com vistas a apurar isso, o Conselheiro Cueva, não se volta, porém, a compreender o que são as organizações societárias em questão de acordo com o direito brasileiro, explorando, por exemplo, o que dispõem as normas que regulam as sociedades cooperativas. Em lugar disso, o Conselheiro propõe que se aplique o roteiro sobre joint ventures médicas desenvolvido pelas autoridades da concorrência norte-americanas Federal Trade Commission (FTC) e Department of Justice (DOJ) - para auxiliar a análise de concentrações nesses casos.

De acordo com esse roteiro, uma joint venture se encontra numa zona de segurança antitruste ${ }^{110}$ caso atenda a critérios baseados no percentual de mercado, no compartilhamento de riscos financeiros e na existência ou não de cláusula de exclusividade $^{111}$. Uma vez fora da zona de segurança, o roteiro instrui que se analise não

\footnotetext{
${ }^{110}$ Trata-se de zona que, ausentes circunstâncias extraordinárias, permite que a autoridade encerre o estudo do caso, ante a pequena probabilidade de preocupações concorrenciais.

${ }^{111}$ Segundo o roteiro, não provocarão preocupações concorrenciais, salvo em casos extraordinários, as joint ventures que: i) possuindo exclusividade, seus participantes compartilhem riscos financeiros e representem $20 \%$ (vinte por cento) ou menos do mercado relevante geográfico; ii) não possuindo exclusividade, seus participantes compartilhem riscos financeiros e representem $30 \%$ (vinte por cento) ou menos do mercado relevante geográfico.
} 
só os efeitos competitivos da joint venture sobre o mercado relevante, mas também as eficiências por ela geradas para o mercado. Na presença de efeitos anticompetitivos e na ausência de eficiências compensatórias, a joint venture não deve ser aprovada.

É com base nesse roteiro que o Conselheiro Cueva aprecia, em diversos processos administrativos ${ }^{112}$, se a cooperativas representadas se justificariam enquanto tais perante o direito antitruste brasileiro. Assim, uma vez constatado que elas não compartilham riscos financeiros e detêm porcentual de mercado maior do que o aceito para integrar a zona de segurança proposta pelo referido roteiro, o Conselheiro se dedica a analisar as eficiências geradas pelas cooperativas:

\begin{abstract}
Analisando os estatutos e a atividade da cooperativa no mercado, será possível avaliar em sua forma de operar, este grau de integração (...) que possa justificar a reunião entre concorrentes. Sob esta ótica, tal reunião só pode ser aceita por uma explicação mais plausível como, por exemplo, possuir objetivos econômicos, de melhoria técnica, redução de custos, aumento de bem-estar, etc. Em outras palavras, há que se ter benefícios reais para os profissionais que, de alguma forma possam se refletir no mercado, gerando, pois, as chamadas eficiências. Caso contrário, a própria atuação da cooperativa no mercado restaria caracterizada como um ilícito antitruste.
\end{abstract}

Não constatando tais eficiências compensatórias da uniformização de conduta, o Conselheiro conclui que a adoção de tabelas de honorários médicos pelas cooperativas constitui um ilícito concorrencial. Mais do que isso até: caso não se constatem eficiências, a própria atuação das cooperativas nos casos analisados seria um ilícito desse tipo. Ele não perquire, portanto, quais os fundamentos jurídicos das cooperativas, se de fato a eficiência é uma característica necessária para que elas restem configuradas ou se o ordenamento pátrio reconhece nesse tipo de organização algum valor que não a eficiência.

Nesse raciocínio, o Conselheiro Cueva é acompanhado por diversos Conselheiros, em uma série de outros casos. O Conselheiro Schuartz, por exemplo, em mais de um caso endossa a tese exposta acima e reitera que, sem eficiência - caracterizada pela integração clínica ou econômica -, não há que se falar em cooperativa (PA nº 08012.005194/200100 e PA n $\left.{ }^{\circ} 08012.007042 / 2001-33\right)$.

O Conselheiro Furquim, do mesmo modo, considera eficiência como critério válido a determinar se cooperativa é ou não um simulacro, na medida em que afirma que

${ }^{112}$ Ver, por exemplo, PAs no 08012.007042/2001-33, no 08012.008060/2004-85 e n ${ }^{\mathrm{o}} 08012.005194 / 2001-$ 00 
embora seja absolutamente consensual na literatura econômica que o compartilhamento de risco, como o praticado pela cooperativa (...) gera ganhos líquidos, não há qualquer indicação de que esses ganhos sejam suficientes para atenuar os prejuízos decorrentes da ação concertada entre os médicos e o ônus da prova de eficiência é das representadas (PA $\mathrm{n}^{\circ}$ 08012.008060/2004-85).

Mesmo em alguns dos casos em que se chega à conclusão de que a cooperativa médica constitui uma forma de organização societária lícita e que pode regularmente determinar o preço dos serviços prestados por seus cooperados, é interessante notar que o argumento empregado também se baseia na noção de eficiência - nesses casos, na existência dela. É nesse sentido, por exemplo, o voto da Conselheira Farina, no PA n ${ }^{\circ}$ 08012.007042/2001-33. Após considerar, nos moldes do apresentado acima, que “competição se dá entre agentes, que podem ser indivíduos ou organizações, mas não entre indivíduos da mesma organização" e que "a legislação não proíbe cooperativas", a conselheira pondera que não há que se falar que as cooperativas seriam meras máscaras jurídicas para encobrir um ilícito antitruste, pois

\begin{abstract}
parece haver racionalidade e incentivos econômicos legítimos na organização dos médicos em cooperativas. É admissível que a cooperativa propicie economia de custos de transação (...) é plausível que a cooperativa, mantendo um setor especializado na análise de glosas seja mais eficiente que o médico autônomo, na medida que o setor especializado acumula informação sobre o comportamento e os critérios de interpretação dos contratos das diversas entidades conveniadas (...) Ademais, a alocação do tempo médico em atividades burocráticas não é eficiente (...). (grifos nossos)
\end{abstract}

A força dos argumentos baseados no funcionamento do livre mercado e na eficiência é manifesta. Tendo tais conceitos como norte da análise da legalidade de condutas sob o ponto de vista do direito concorrencial, a jurisprudência do Conselho predominantemente considera a ilicitude das tabelas em questão como algo autoevidente. Isso se mostra de forma clara pelo fato de que, uma vez constatada a existência de tabela, suas decisões prescindem, em grande medida, de maiores considerações sobre eventuais particularidades dos casos analisados.

Nesse sentido, as nuances de como a tabela é implementada em cada caso são largamente irrelevantes na determinação da ilicitude da mesma. Os casos em que há meramente elaboração e divulgação de tabela recebem, em grande parte da jurisprudência, tratamento idêntico aos casos em que as entidades representativas dos médicos se utilizam de ameaças (descredenciamento, processo ético-disciplinar, etc.) para 
fazer valer suas tabelas junto a esses últimos ${ }^{113}$. É, inclusive, amplamente empregado o argumento de que a jurisprudência da autoridade é clara e consolidada no sentido de não exigir que a tabela seja impositiva para ser ilícita, haja vista que, mesmo a tabela sem qualquer tipo de coerção, afetaria o poder de decisão individual de cada agente econômico para estabelecer seus próprios preços ${ }^{114}$. Em outros casos, apesar de a coerção ser apontada como evidência da ilicitude da conduta, não se coloca que tal ilicitude decorre estritamente da coerção. Os incentivos ao boicote a certas operadoras ou a existência de ameaças a médicos que não atenderem às determinações das entidades representativas são, então, apresentados como elementos que compõem o ilícito concorrencial, mas não consta de maneira expressa se, na ausência dessas práticas, a ilicitude ainda restaria configurada $^{115}$.

Além de frequentemente não diferenciar as tabelas com base nos meios utilizados para garantir que elas sejam respeitadas pelas operadoras e pelos prestadores de serviço, o Cade tampouco costuma diferenciá-las em função do agente que as implementa.

Uma evidência disso é fato de que o órgão frequentemente aplica indistintamente suas decisões sobre tabela de serviços laboratoriais e hospitalares aos casos envolvendo tabelas de honorários médicos. Assim, uma vez constatada a existência de tabela sugestiva de preço, os argumentos aplicados a laboratórios e hospitais ou a entidades representativas desses dois são integralmente transpostos aos casos envolvendo entidades representativas de médicos, cooperativas e clínicas. Essa abordagem fica clara pela integral incorporação de votos referentes a tabelas impostas por laboratórios a casos em que se discute a legalidade de tabelas de honorários médicos, sem que qualquer ressalva seja feita quanto à diferença de poder de barganha de que dispõem os hospitais e os profissionais médicos individualmente considerados ${ }^{116}$.

Por fim, outro aspecto que evidencia que, uma vez constatada a existência de tabela, as decisões do Cade prescindem, em grande medida, de maiores considerações

\footnotetext{
113 Vale notar que há casos nos quais, embora se fale num ilícito decorrente tanto de uma conduta concertada, quanto do abuso de posição dominante, não se delineia expressamente os contornos de cada conduta, fala-se. Ver, por exemplo, os votos do Conselheiro Cueva nos PAs nº 08012.005194/2001-00 e 08012.008060/2004-85.

${ }^{114}$ Ver, por exemplo, PAs no 08000.021976/1997-51 e nº 08000.010318/94-73.

115 Ver, nesse sentido, os votos do Conselheiro Eduardo Pontual nos PAs no 08012.006552/2005-17, $\mathrm{n}^{\circ}$ 08012.005135/2005-57, $\mathrm{n}^{\mathrm{o}}$ 08012.008477/2004-48.

116 Ver, nesse sentido, PAs $n^{\circ} 156 / 94, n^{\circ} 158 / 94, n^{\circ} 173 / 94, n^{\circ} 174 / 94$, nos quais a relatora incorpora em seu voto o PA $\mathrm{n}^{\circ}$ 155/94, que condena laboratórios por tabela sugestiva de preço.
} 
sobre eventuais particularidades dos casos analisados, é o fato de o Conselho não se debruçar sobre o contexto em que se insere a tabela sugestiva de preços para honorários médicos. Em outras palavras, a dinâmica e as particularidades próprias à relação entre operadoras de planos de saúde e prestadores de serviços médicos são comumente desconsideradas pelo Conselho ao avaliar a licitude da conduta.

Há que se notar que não são poucas as manifestações das partes no sentido de chamar a atenção do Conselho para o fato de que o ideal de livre mercado, em que os médicos negociariam caso a caso com as operadoras o preço do serviço prestado, com base tanto em seus méritos quanto em seus custos, não corresponde à realidade do funcionamento desse mercado. As representadas constantemente apontam que as operadoras, ao invés de negociar individualmente cada contrato de modo a estabelecer preços que refletem a "especialidade, notoriedade e experiência" de cada profissional, realizam verdadeira imposição de preços e condições. O relatório do PA nº 011518/9406 coloca isso de maneira clara:

\begin{abstract}
[A]s representadas (...) declaram que o CIEFAS ${ }^{\mathbf{1 1 7}}$ vem tentando impor aos médicos de Sergipe uma tabela e um CH [Coeficiente de Honorários] já extintos desde 1993 pela AMB [e que] se tal prática [acordo que fixa preço único para a prestação de serviço] veio a ocorrer foi nas muitas ocasiões em que o CIEFAS definiu e ditou os preços dos procedimentos médicos e consultas a serem cobrados pelos milhões de agentes médicos de todo o país $^{118}$. (grifos nossos)
\end{abstract}

Outros exemplos de casos em que as representadas relatam dificuldade de negociar com as operadoras de planos de saúde que insistem em não conceder reajuste nos valores de honorários médicos se encontram nos relatórios dos PAs $\mathrm{n}^{\circ}$ 08012.006397/97-02 no 08000.021054/96-27. Neste último, além de afirmar que é a representante (operadora de autogestão) quem impõe os preços e de observar que sua conduta é uma contraposição ao valor imposto pela operadora, a representada ainda faz notar o fato de que os médicos compõem um mercado sabidamente disperso e atomizado.

No PA nº 08000.021976/1997-51, por seu turno, as representadas trazem diversos elementos concretos que jogam luz sobre a dinâmica da relação entre operadoras e prestadores de serviços médicos. Nele, elas primeiramente alertam para o fato de que, mesmo antes da elaboração de tabela por entidades representativas de médicos, não havia

\footnotetext{
${ }^{117} \mathrm{O}$ Comitê de Integração de Entidades Fechadas de Assistência à Saúde - CIEFAS é entidade representativa de operadoras de autogestão e representante do processo administrativo em questão.

118 Trata-se de Processo Administrativo de relatoria do Conselheiro João Bosco Leopoldino da Fonseca.
} 
realmente barganha individual com a representante (sindicato das empresas de medicina de grupo):

[T]ais empresas de saúde, através de suas associações, estipulavam os preços dos honorários médicos; e estipulavam também quais procedimentos (exames) que estes médicos poderiam solicitar a seus pacientes. Comportamentos estes que impediam estes médicos, individualmente, de negociar seus honorários e os procedimentos a serem solicitados. Na realidade, a intenção das empresas de saúde, através de suas associações, era neutralizar qualquer iniciativa individual de negociação dos médicos. (grifos nossos)

As representadas também explicam como são firmados os contratos entre operadoras e prestadores de serviço e afirmam que existe uma dependência dos médicos em relação às operadoras:

[A]s empresas de medicina de grupo e até mesmo as caixas assistenciais celebram com os médicos, laboratórios e hospitais, os chamados contratos de credenciamento. Tais contratos podem ser classificados como contratos de adesão, uma vez que todas as condições são impostas pelas empresas, ficando o médico, profissional liberal, totalmente submisso às cláusulas: o que ofende frontalmente os princípios constitucionais da livre concorrência e da livre iniciativa, pois raras são as consultas efetuadas a pacientes particulares, que não pertencem a um grupo de empresa de saúde. (grifos nossos)

Partindo do argumento de que inexiste negociação individual com os médicos e de que os contratos celebrados entre esses últimos e as operadoras são de adesão, as representadas se voltam também contra a ideia de que, na ausência de uma tabela colocada pelos médicos, a livre negociação refletiria melhor os atributos dos médicos e as especificidades dos serviços prestados:

[T] odo procedimento constante dos contratos de credenciamento tem seus valores fixados através de uma determinada tabela. Tabela essa utilizada por todos os credenciados, sem levar em conta a capacidade profissional do médico, se o mesmo tem ou não título de especialista, se é ou não um profissional atualizado (...). (grifos nossos)

Com vistas a atestar a uniformização de preços por parte das operadoras, as representadas inclusive apresentam, no Processo Administrativo em comento, contratos firmados nos quais constam cláusulas por meio das quais as operadoras impõem a seus contratados suas tabelas de honorários.

As representadas sustentam, ainda, que a disparidade na barganha entre operadoras e médicos, evidenciada - segundo elas - pelos argumentos acima, é agravada 
pelo fato de que a maioria das empresas de medicina de grupo e caixas assistenciais celebra contratos de credenciamento através de suas associações e sindicatos, o que faz com que as condições e preços sejam homogêneos.

Nota-se, portanto, que os elementos trazidos à discussão pelas representadas nos processos acima citados constituem verdadeira objeção à ideia de livre mercado em que cada médico, com base em seus custos e méritos individuais, negocia com as operadoras de planos de saúde seus preços. É dizer, o argumento de que os mecanismos de mercado, através das forças de oferta e demanda, inibiriam a uniformização e imposição de preços por uma das partes e evitariam que desiguais (médicos com diferentes competências) fossem igualados, não corresponde à descrição de como o mercado em questão funciona concretamente.

Não obstante tantas objeções à concretização do ideal funcionamento do mercado defendido pelo Conselho, este último, ao decidir os referidos casos, mesmo que narre esses fatos, se restringe, habitualmente, a fazer considerações sobre a ilicitude da tabela de maneira genérica e abstrata. Conforme exposto, as decisões da autoridade, pela ilicitude da tabela sugestiva de preços de honorários médicos, são largamente baseadas no argumento de que as forças de mercado são aptas a atingir o preço de equilíbrio e a impedir a imposição de preço por qualquer das partes, bem como na ideia de que toda a conduta tem de ser eficiente para ser lícita concorrencialmente. Em geral, o maior grau de concretude que se obtém da jurisprudência do Cade sobre esse tema é através de ponderações no sentido de que cabe exclusivamente ao médico estipular seus honorários, de que tal jurisprudência não exige que a tabela seja impositiva para ser ilícita e de que a divulgação de tabela de preços evitaria que os preços fossem determinados pelas regras de mercado.

Aqui, há que se fazer a ressalva de que os argumentos colocados pelas entidades representativas de médicos não passam desapercebidos a todas as decisões do Conselho. No que tange às cooperativas, por exemplo, alguns conselheiros argumentam que a licitude dessa forma de organização e da utilização da tabela médica como referencial não se baseia estritamente em argumentos de direito privado, referentes a liberdade de contratar. Seu entendimento é de que a atuação da cooperativa teria, sim, sentido para além da mera colusão para obter preços artificialmente mais altos: ela serviria para equilibrar uma relação entre agentes com poderes bastante distintos. 
Nesse sentido, a Conselheira Farina argumenta, no já mencionado PA $n^{\circ}$ 08012.003664/2001-92, que “[h]á lógica da ação coletiva na atuação das cooperativas, para equilibrar posição na barganha de seus contratos" ${ }^{119}$. O Conselheiro Pfeiffer também afirma, no mesmo processo: "parece-me legítimo que os médicos organizem-se por meio de cooperativa, o que lhes permite, inclusive, melhores condições de negociar com as operadoras de planos de saúde e seguro-saúde, detentores [sic.] de inegável poder de barganha".

Já nessas manifestações, deixa-se antever a ideia de que a licitude de determinada forma de organização, mesmo sob o ponto de vista do direito concorrencial, não se restringe aos casos em que se constata eficiências. Ao esclarecer que a lógica das cooperativas pode estar amparada na necessidade de equilibrar uma relação entre as partes de uma transação, alguns conselheiros demonstram que entendem não apenas que o direito concorrencial não é informado tão somente pelo ideal de eficiência, como também que ele se insere em um ordenamento mais amplo, com uma racionalidade própria, distinta da racionalidade que orienta a teoria econômica.

Outro exemplo de que as alegações das partes representadas não passam desapercebidas por todos os conselheiros da autoridade é o voto do Conselheiro Paulo Furquim, no PA $n^{\circ}$ 08012.007042/2001-33. Nele, o conselheiro traz valorosas contribuições que reforçam a ideia de que, apesar de a eficiência constituir um elemento a ser ponderado na análise antitruste, ela não deve figurar sozinha nesse processo.

Em seu voto, a tese do poder compensatório é tratada, pela primeira vez, de maneira estruturada. De acordo com ele, a ideia de se admitir a criação de um poder que compense uma assimetria de um poder de barganha pré-existente está ligada à própria origem do direito antitruste. Isso porque, o fundamento para a aplicação da defesa da concorrência é a própria assimetria entre os atores econômicos, uma vez que, "[f]ossem todos equivalentes em sua capacidade de influenciar os mercados, não haveria motivos

${ }^{119}$ Vale notar que o posicionamento da Conselheira Farina é bastante oscilante nos casos envolvendo o tema em comento. 
para o controle do poder de mercado"120 121 . Logo - conforme explica o Conselheiro -, o intuito de dotar agentes com a capacidade para lidar em bases equivalentes em uma situação de barganha é o princípio legitimador a amparar não apenas as cooperativas, mas qualquer forma de associação que represente esse papel de coordenação horizontal, contanto que não prejudique o consumidor ${ }^{122}$.

Em face disso, o Conselheiro chama a atenção para a necessidade de se atentar para as especificidades dos casos concretos analisados sob a ótica do direito antitruste. Tratar todas as hipóteses de coordenação horizontal como idênticas, desconsiderando a existência de assimetria de poder de barganha entre as partes, contrariaria, segundo ele, a lógica do direito concorrencial ${ }^{123}$.

Além de identificar uma relação entre as origens da defesa da concorrência e o objetivo de se corrigir uma assimetria de poder, o Conselheiro também afirma em seu voto que a própria literatura econômica (ou ao menos parte dela) reconhece que fusões

\footnotetext{
120 Nos termos do Conselheiro Paulo Furquim, no PA no 08012.007042/2001-33: Nos termos do Conselheiro Paulo Furquim, no PA n ${ }^{\circ}$ 08012.007042/2001-33: “ o fundamento para a aplicação da defesa da concorrência é a assimetria entre os atores econômicos, que, para alguns, é resultado inevitável da própria concorrência. Fossem todos - fornecedores, processadores, distribuidores e consumidores - numerosos e equivalentes em sua capacidade de influenciar os mercados, não haveria motivos para o controle do poder de mercado. Entretanto, raramente este é o caso. Daí a importância de um sistema que quando possível, preserve as condições de concorrência entre empresas e consumidores.

${ }^{121}$ Para subsidiar esse argumento, o Conselheiro faz, inclusive, uma digressão histórica sobre a defesa da concorrência, traçando um paralelo entre ela, a origem de movimentos trabalhistas, a consolidação do cooperativismo e o surgimento dos primeiros mecanismos de proteção aos consumidores. $\mathrm{O}$ denominador comum desses movimentos é, segundo ele, "a criação de um quadro institucional voltado à proteção dos interesses daqueles que apresentavam maiores custos de coordenação para se fazerem representar autonomamente". Esse quadro institucional, segundo ele - e nos moldes do apresentado no início do presente trabalho -, se mostrou dinâmico, e, a despeito de eventuais conflitos iniciais, a legislação antitruste norte-americana, foi gradativamente transformada ${ }^{121}$ - de modo a compatibilizar a defesa da concorrência com a existência de sindicatos e cooperativas - com base na ideia de poder compensatório.

${ }^{122}$ Nos termos do Conselheiro Paulo Furquim, no PA no 08012.007042/2001-33: "nas palavras de Frederick, uma das razões para permitir a ação conjunta por meio de cooperativas era 'promover seu poder econômico, de modo a dotá-las de capacidade para lidar em bases equivalentes com processadores e distribuidores'. Com base nesse princípio, não somente cooperativas eram protegidas, mas qualquer forma de associação que representasse o mesmo papel de coordenação horizontal, desde que não prejudicasse consumidores finais. Essa ressalva é essencial para identificar os limites da permissividade da organização cooperativa. O princípio que sempre orientou esse caminho de consolidação institucional foi o de refrear os efeitos adversos das inevitáveis assimetrias de negociação entre os atores econômicos. Dessa forma, a pertinência das condutas uniformes por parte de trabalhadores e cooperativas decorre da existência prévia de assimetria. Por esse motivo, práticas sindicais e de cooperativas são condenadas se implicarem abuso de poder, ou inversão da assimetria de negociação, que constitui o pressuposto para a sua tolerância por parte das autoridades antitruste". (grifos nossos)

${ }^{123}$ Nos termos do Conselheiro Paulo Furquim, no PA n ${ }^{\circ}$ 08012.007042/2001-33: "aplicar a defesa da concorrência, sem maiores qualificações, para impedir a organização de fornecedores de serviços por meio de associações ou cooperativas - sem dúvida, formas de coordenação horizontal - é contradizer o princípio que deu origem e justifica a própria existência do sistema de defesa da concorrência". (grifos nossos)
} 
ou mesmo condutas uniformes de comercialização são benéficas, do ponto de vista social, nos casos em que resultam em poder compensatório. Isto é, em que se verifica uma contraposição ao poder prevalecente de uma dada contraparte em uma negociação qualquer ${ }^{124}$. É por isso que, mesmo uma análise sob a ótica da teoria econômica, voltada à aferição do bem-estar líquido gerado por uma conduta, não poderia desconsiderar as particularidades do contexto em que essa conduta se insere. Somente a partir dos elementos do caso concreto (se os termos da transação, como preço, quantidade, qualidade e alocação de riscos, são definidos de maneira descentralizada ou em uma barganha bilateral) é que se poderia avaliar se certa conduta uniforme é admissível ou não ${ }^{125126}$.

Para além da assimetria do poder de barganha e da tese do poder compensatório, primeiramente aventado pelo Conselheiro Furquim, outros Conselheiros chamam a atenção para aspectos diversos da relação, entre os agentes do mercado de saúde

\footnotetext{
${ }^{124}$ Tendo por base a tese de J.K. Galbraith, o Conselheiro explica que o poder compensatório se sustenta na ideia de que os efeitos deletérios de uma relação muito assimétrica podem ser atenuados no caso de a parte desfavorecida reunir condições para contrabalancear a negociação ${ }^{124}$. O que, por sua vez, diferencia a hipótese de poder compensatório daquela em que ocorre o problema de dupla-margem - ou seja, daquela em que a concentração em elos sucessivos de uma cadeia de produção resulta na redução do bem-estar social e no aumento do preço do consumidor final - é a existência ou não da interdependência entre as partes: "do ponto de vista teórico, é fundamental notar se as partes entram em um processo de barganha bilateral ou se tomam suas decisões sem considerar a interdependência de suas ações. Em casos concretos, é fundamental notar se há um processo descentralizado de negociação, onde poderia ocorrer duplamargem, ou uma barganha bilateral, em que diversos termos da transação, como preço, quantidade, qualidade, alocação de riscos, entre outros, são definidos" ${ }^{124}$. (grifo nosso)

${ }^{125}$ Essa admissibilidade, observa o Conselheiro, se daria apenas em hipóteses muito específicas: [c]oncluise que a conduta uniforme na comercialização é admissível em condições bastante restritivas: a) existência de forte assimetria de negociação ex-ante e em desfavor daqueles que buscam se coordenar; b) que a coordenação horizontal resulte em uma mudança no padrão de negociação, de descentralizada, para uma barganha bilateral; e c) que aquilo que seria um poder compensatório não inverta a relação de assimetria que é o pressuposto para sua tolerância. (grifos nossos)

${ }^{126} \mathrm{Na}$ análise da licitude da conduta apreciada no PA em questão, para determinar se estavam presentes as condições necessárias para que uma conduta uniforme seja considerada admissível, o Conselheiro se voltou aos elementos do caso concreto. Assim, ao avaliar a existência de forte assimetria de negociação ex-ante, ele ponderou que havia evidências de que as operadoras de planos de saúde (entidades de autogestão, no caso) adquiriam os serviços médicos de maneira conjunta, por um "Comitê de Negociações"; que o Conselho já havia expressado várias vezes o fato de esses planos atuarem "no sentido de aviltar a remuneração dos profissionais"; e que a própria ANS havia afirmado em reunião do plenário Cade que seria "negligenciável a possibilidade de venda dos serviços médicos diretamente ao paciente". Da mesma forma, ao apreciar se a coordenação horizontal dos médicos havia levado a uma mudança no padrão de negociação, possibilitando uma barganha bilateral, o Conselheiro considerou as narrações factuais presentes nos autos, que revelavam reuniões para definição dos termos do contrato e negociação continuada entre as partes. Por fim, ao avaliar se o poder compensatório criado invertia ou não a relação de assimetria, o Conselheiro levou em consideração não apenas a fatia de mercado detida pela representada, como também averiguou se existia qualquer mecanismo de coação e retaliação aos médicos cooperados que prestassem serviço a outras organizações. Com base nesses argumentos, o Conselheiro votou pelo arquivamento do processo em questão, posicionamento no qual foi, contudo, vencido. Não obstante, vale observar que esse caso marca uma verdadeira divisão do Conselho. Dentre os sete conselheiros, três se manifestaram pelo arquivamento do processo.
} 
suplementar, que merecem, igualmente, consideração. As diversas manifestações do Conselheiro Delorme Prado, em casos sobre esse tema, é exemplo disso.

Para ele, é necessário que a autoridade se atente não apenas para o fato de que as relações de poder entre as operadoras e os prestadores de serviços individualmente considerados tendem a ser assimétricas e que o subsiste na ausência de tabelas médicas são contratos de adesão apresentados pelas OPS. O Conselheiro também destaca que o bem-estar do consumidor, além de ser afetado pelo preço do serviço, também depende de sua qualidade e esta, diante da impossibilidade de negociação em virtude da assimetria no poder de barganha, provavelmente restaria comprometida (PA n ${ }^{\circ} 08000.020294 / 1996$ $03)$.

Além disso, no PA no 08012.005194/01-00, o mesmo Conselheiro critica a maneira como o Cade tende a deliberar sobre os casos de tabela médica e sustenta que "[n]ão se pode aplicar de forma acrítica um modelo universal de teoria econômica a qualquer país e qualquer formação social, sem considerar as características históricas, sociais e institucionais dessa sociedade".

A partir disso, o Conselheiro não se limita a esclarecer que o controle antitruste pode ter por objetivo outros fins que não meramente a eficiência alocativa, tais quais, a eficiência dinâmica e distributiva, a inovação, a diversificação de produtos, dentre outros. Ele chama atenção especificamente para a relevância de se atentar para o aspecto jurídico desse controle e para as prioridades a serem estabelecidas tendo em vista o que prevê o ordenamento jurídico. Afinal, afirma o Conselheiro, "a livre concorrência é um princípio da ordem econômica, mas este está subordinado à função social da propriedade e à valorização do trabalho humano, ou seja, prioriza-se a dignidade do indivíduo, que é o sujeito da lei, a um conceito abstrato de eficiência".

Outra importante dissidência dentro da jurisprudência do Cade sobre tabelas médicas se encontra nas manifestações da Conselheira Ana Frazão ${ }^{127}$. De acordo com ela, não apenas uma série de fatos e argumentos deveria ser considerada pela autoridade quando da realização de sua análise, como a própria abordagem da autoridade - em grande medida surda a ponderações jurídicas - deveria ser repensada. Mesmo porque,

${ }^{127}$ As manifestações da Conselheira Ana Frazão aqui transcritas são extraídas de seu voto no PA $\mathrm{n}^{\circ}$ 08012.006552/2005-17. No entanto, importa notar que elas são reiteradas pela Conselheira em outros votos seus sobre o tema. 
conforme observa a conselheira, a "controvérsia não está propriamente na existência ou não de desigualdade entre os médicos e operadoras - que é reconhecida unanimemente mas nos limites admitidos pelo direito antitruste para endereçar o problema" ${ }^{28}$. Com base nisso, ela evoca uma gama de considerações jurídicas que, até então, sequer eram objeto de apreciação pelo Cade.

Nesse sentido, a Conselheira lembra que os processos administrativos julgados pela autoridade antitruste, como qualquer outro processo dessa espécie, são regidos pelo princípio da verdade real, de modo que "a Administração Pública, em vez de ficar restrita ao que as partes demonstrem no procedimento, deve buscar realmente a verdade, em atenção à indisponibilidade ao interesse público". A observância a esse princípio se revela ainda mais elementar face do fato de que tais processos possuem nítido viés punitivo, o que exige especial cautela com o emprego de presunções. Considerando que a responsabilidade objetiva não se coaduna com direito administrativo sancionador sendo, portanto, inadmissível desconectar a sanção da culpabilidade - subsiste, segundo a Conselheira, a necessidade de se analisar a existência de excludentes de antijuridicidade e de culpabilidade.

Com base nisso, a Conselheira Ana Frazão enfatiza que a própria análise de poder compensatório tem de ser realizada sob um enfoque jurídico, perquirindo sobre a reprovabilidade da conduta. Segundo ela, embora o exame dessa tese (poder compensatório) venha se concentrando nas hipóteses de monopsônio ou oligopsônio "até porque, em geral, os estudos sobre o tema têm unicamente um viés econômico e preocupam-se, prioritariamente, com os efeitos da coordenação horizontal sobre os preços dos planos de saúde" -, cabe avaliar se o poder compensatório pode figurar como excludente de ilicitude de conduta, mesmo quando essas hipóteses não se verem preenchidas. Isso porque ele (poder compensatório) pode estar sendo utilizado para se contrapor a uma posição dominante existente, a fim de evitar que esta abuse de seu poder.

\footnotetext{
${ }^{128}$ De fato, conforme registra a Conselheira Frazão, mesmo os conselheiros que consideram as tabelas ilícitas em qualquer hipótese, tendem a reconhecer a assimetria de poder de barganha entre os agentes desse mercado. A título de exemplo, menciona-se a manifestação do Conselheiro Cueva no PA $n^{\circ}$ 08012.005194/2001-00: "não se nega aqui que o poder de mercado das empresas tomadoras de serviço de saúde, eventualmentem justificaria a filiação de médicos a organizações aptas a se contrapor a uma tal excessiva concentração de poder. Mas não considero tal fato como suficiente para autorizar uma ação coordenada que, fixando preços, acabe por impedir a formação natural de preços"(grifo nosso). Registra-se, aqui, também, a facilidade com que a constatação de uma característica concreta do caso (assimetria do poder de barganha) é descartada com base em um argumento teórico abstrato (comprometimento da "formação natural de preços").
} 
Em linha com essas considerações, a Conselheira destaca a elementaridade de se preservar o elemento jurídico nas análises dos casos envolvendo tabelas médicas

Sob a ótica deontológica e vinculante do direito, ao analisar a conduta dos agentes econômicos, é imprescindível examinar se ela está em conformidade com os princípios e regras jurídicas pertinentes, ou seja, se pode ser considerada legítima diante da racionalidade própria do direito, a ser desenvolvida por um juízo de fundamentação e aplicação dos princípios constitucionais e demais normas jurídicas.

Nesse sentido, ela também critica a identidade estabelecida, pela jurisprudência, entre eficiência e licitude. Segundo ela, ainda que se admitisse que a conduta em questão não traz qualquer incremento de eficiência ao mercado de saúde suplementar, tal constatação por si só, não a tornaria ilícita. Tal entendimento, apesar de comum, reflete de acordo com a Conselheira - meramente de uma tradição welfarista que - nos moldes do já apresentado no presente trabalho - tem como pernicioso resultado uma desconstitucionalização do direito da concorrência. Mais especificamente, trata-se, segundo ela, de uma

ampla e irrefletida aceitação da análise antitruste baseada exclusivamente em critérios econômicos consequencialistas, que teria sido adotada no Brasil como 'referencial normativo indisputado, pronto e acabado para uso imediato, tornando-se uma norma quase-evidente.

Aqui, a conselheira, além de ressaltar os próprios limites da teoria econômica indicando que os instrumentos por ela oferecidos não eliminam nem a incerteza, nem a imprecisão -, aponta que os casos de tabelas médicas são compostos por uma série de elementos concretos ${ }^{129}$ que tornam clara a necessidade de se demonstrar maior humildade

\footnotetext{
${ }^{129}$ Os votos da Conselheira Frazão são especialmente ricos, na medida em que fazem um apanhado bastante robusto da própria jurisprudência do Cade e dos argumentos e fatos trazidos à baila, por diferentes partes, ao longo dos anos. Nesse sentido, a Conselheira nota, por exemplo, que é "curioso e preocupante que as mesmas OPSs que se unem em negociação coletiva para aumentar seu poder de barganha frente aos médicos, sem vislumbrar nenhum problema antitruste nessa iniciativa, venham a bater às portas do SBDC para denunciar os médicos quanto são estes que tentam negociar coletivamente. Para Furquim e Almeida, os dados indicam a possibilidade de que o SBDC tenha sido utilizado como árbitro para solucionar conflitos privados entre as associações de médicos e as operadoras de planos de saúde" (grifos nossos). A Conselheira também observa que Furquim e Almeida realizaram análise empírica a qual demonstrou que "existem impactos positivos associados à criação do poder compensatório cristalizado na ação coordenada dos médicos. Assim, o Cade pode ter [condenado] práticas que, em última análise, poderiam levar à redução de preços aos consumidores finais". Outro dado interessante, recuperado pela Conselheira, que lança dúvida sobre os alegados malefícios decorrentes da tabela médica, provém de estudo da própria Secretaria de Direito Econômico (SDE) sobre negociações no mercado de saúde suplementar, que registra que $44,73 \%$ das operadoras por ela questionadas afirmaram que as negociações individuais, com cada médica, acarretariam um aumento de custos. Por fim, vale também mencionar referência da Conselheira a estudo da SDE no PA $n^{\circ}$ 08012.002039/2010-05, o qual evidencia que não é prática recorrente adotar honorários diferenciados, em razão de qualificação, experiência e reputação profissional ( $84 \%$ das operadoras oficiadas responderam que não adotam diferenciação dos honorários, segundo esses critérios). Tal estudo desconstrói, portanto, o argumento amplamente utilizado de que, na
} 
e desconfiança em relação à ideia de perfeição dos mecanismos de mercado. Mesmo porque, "havendo posição dominante da outra parte, não há que se falar propriamente em livre concorrência". Ademais, trata-se, segundo ela, de setor complexo e problemático, que requer que o bem-estar do consumidor seja protegido de forma diferenciada: não apenas em relação a preço, mas também no que diz respeito à oferta do serviço e sua qualidade.

Assim, ao contrastar uma série de fatos e argumentos com as disposições legais que disciplinam a defesa da concorrência no Brasil - e aqui incluem-se não apenas a Lei $\mathrm{n}^{\mathrm{o}}$ 12.529/11, que dispõe especificamente sobre a matéria, mas outras normas que informam o direito concorrencial -, a Conselheira Frazão conclui que, diante da assimetria de poder de barganha entre operadoras e prestadores de serviços, a ilicitude da tabela médica se verifica nas hipóteses em que for levada a cabo alguma prática que exceda o poder compensatório (através de ameaças, via descredenciamento, por exemplo), fazendo com que a tabela extrapole a reinvindicação por honorários médicos não aviltantes. Segundo ela, portanto, a existência de ameaça - a ser averiguada no caso concreto, sob análise - é fundamental para determinar se a tabela médica sob julgamento é lícita ou não. Essa licitude, ademais, deve ser aferida com base em ponderações jurídicas e, ainda que a teoria econômica sirva como instrumento de análise antitruste, esta última não deve estar calcada estritamente em argumentos econômicos abstratamente considerados, indiferentes tanto aos fatos, quanto ao direito.

Não obstante toda a variedade de argumentos trazidos pelos votos que dissentem da orientação majoritária do Cade, a autoridade não apresenta, via de regra, abertura para sua apreciação de fato. Na realidade, para além das decisões que sequer atentam para as características próprias ao setor de saúde suplementar e para a correspondência entre o funcionamento deste e do ideal de mercado preconizado, há um número não desprezível de manifestações do Cade que chamam a atenção para as particularidades do referido

ausência de tabelas médicas, e sob a vigência das forças de mercado, as operadoras, ao negociar com os médicos individualmente, levariam em conta as particularidades de cada serviço (ou, no caso, de seu prestador) para a formação de seu preço, evitando que esse último fosse estabelecido uniformemente. 
setor, mas não incorporam esses mesmos elementos às decisões exaradas ${ }^{130131}$. Nesses casos, após ponderar uma série de elementos que exigiriam uma flexibilização dos pressupostos teóricos econômicos habitualmente empregados na análise antitruste, os conselheiros acabam por amparar suas decisões em considerações abstratas referentes a

${ }^{130}$ Exemplos bastante paradigmáticos de casos nesse sentido são os votos do Conselheiro Mércio Felsky, no PA no 08000.011517/94-35 e no PA n ${ }^{\circ}$ 08000.022630/97-52. Neles, o Conselheiro fornece até mesmo informações relevantes para a compreensão do setor, as quais ele mesmo ignora ao emitir sua decisão. Mais especificamente, no primeiro deles, ao ponderar que as tabelas de preços médicos são uma reação tanto à imposição pelas operadoras dos valores dos serviços médicos, quanto à interferência dessas empresas nas condições de trabalho desses profissionais, cita estudo que investiga a situação dos médicos no Brasil: "pode-se dizer que a tabela é uma resposta ao poder de mercado que passaram a ter esses novos agentes no mercado, as empresas de convênio ou planos de saúde. Estas, detentoras de uma invejável carteira de clientes usuários de serviços médicos, fruto mesmo do encarecimento desses serviços, passam a intermediar a prestação de serviços, contratando-os dos médicos. Os profissionais médicos se dão conta de que a clientela não está mais livre, individualizada e dispersa no mercado (...). Com a entrada das empresas intermediárias de saúde, os médicos perdem, em grande parte, a autonomia técnica e econômica, fundamento da prática liberal (...) posta em xeque por diversas forças transformadoras das relações de trabalho." (Os médicos no Brasil: um retrato da realidade, coordenado por Maria Helena Machado, Rio de Janeiro, Fiocruz, 1999, grifo nosso). Já no PA nº 08000.022630/97-52, o mesmo conselheiro faz eloquente exposição sobre como a remuneração dada aos médicos pode interferir na qualidade de seu trabalho, de modo que há aqui, pela primeira vez na jurisprudência do Cade, uma reflexão sobre o impacto da tabela médica sobre os consumidores para além da questão do eventual aumento do preço. De acordo com ele, não se deve descartar "a evidência empírica de que a qualidade do atendimento médico guarda uma íntima relação com o valor recebido pela consulta ou pelos serviços prestados pelo médico", nem que, "como empresa, é racional que esses convênios possam privilegiar a busca de lucro". Em face dessas observações, o conselheiro avalia que: “(...) num mercado com essas características, nada garante que o banimento da tabela de honorários ou lista de procedimentos, editadas pela AMB, repercuta diretamente em benefícios ao consumidor, e não em aumento de lucro para as empresas. Além disso, como já foi observado, a tabela nem sempre funciona como piso dos honorários médicos". O conselheiro também aponta que, no Brasil, a "tendência do mercado da medicina privada é de inspirar-se cada vez mais no sistema americano (Managed Health Care), que [sic.], segundo algumas opiniões, o maior objetivo é maximizar lucros para executivos e investidores". Segundo ele, além de o sistema norte-americano ser avaliado muito negativamente pela população, especialistas entendem que a maneira como o Managed Care trata os médicos compromete a qualidade do serviço por eles prestados. Apesar dessas considerações sobre i) o poder que as operadoras têm sobre o trabalho e a remuneração do médico; ii) sobre como o preço pago pelo serviço pode afetar sua qualidade; iii) sobre os incentivos que as operadoras têm de reduzir ao máximo seus custos, sem necessariamente repassar tal redução ao consumidor; e iv) sobre como o setor de saúde suplementar brasileiro progressivamente se aproxima de um sistema de saúde de méritos contestáveis, o conselheiro, em ambos os casos, acaba por decidir com base no argumento de que as eficiências ${ }^{130}$ de um mercado livre não seriam superadas por aquelas eventualmente produzidas pela tabela sugestiva de preços, sem elaborar em maiores detalhes como esse sopeso ocorreu no caso concreto ${ }^{130}$. As ressalvas sobre o setor, diligentemente pontuadas pelo conselheiro, são, então, facilmente colocadas de lado em nome de um modelo de mercado abstrato. Exemplo disso é que, feitas as acuradas ponderações sobre os problemas e limites do modelo americano, o conselheiro se contenta em afirmar: "apesar dos problemas acima, acredito que o modelo americano possa servir como indicativo de que é possível a competição no setor de serviços médico-hospitalares, num contexto de mercado, com organizações apropriadas à competição, diferente do que tem sido no Brasil, com a intervenção das entidades representativas da classe médica".

${ }^{131}$ Outro exemplo de decisão nesse sentido (além dos PAs no 08000.011517/94-35 e n 08000.022630/9752) é o PA n 0 08012.006397/97-02 em que o conselheiro Roberto Pfeiffer assevera, por exemplo, que "[n]ão se nega a legítima possibilidade da associação representar os seus associados em negociações com as empresas de planos de saúde devido às peculiaridades da relação entre médicos e planos de saúde". Também nesse caso, apesar de notar que o setor em discussão possui particularidades que justificariam uma abordagem mais cautelosa, o relator se satisfaz em decidir com base no histórico jurisprudencial do Cade, que considera ilícitas tabelas de preços de qualquer tipo, uma vez que sua divulgação evitaria que os preços fossem determinados pelas regras de mercado. 
esses mesmos pressupostos. Tratam-se de manifestações que, ao mesmo tempo em que são especialmente confusas, ilustram a força da racionalidade econômica nas análises em comento. De qualquer modo, são, em ambos os casos (decisões que não se atentam para qualquer particularidade do caso e decisões que mencionam tais particularidades, mas acabam por ignorá-las), decisões que tomam as tabelas médicas por ilícitos concorrenciais, sem adentrar uma análise de seus efeitos no caso concreto.

Em outras palavras, embora haja, em alguns casos, menção a particularidades do mercado em comento - como, por exemplo, à existência de assimetrias de informação, de assimetria no poder de barganha, do risco de se considerar o bem-estar do consumidor tão somente com base no preço -, não se explora, via de regra, como essas particularidades se refletem na interpretação e aplicação das disposições legais ao caso concreto. Conforme exposto, a adesão quase-incondicional à teoria econômica, com seus modelos fechados, supostamente capazes de oferecer análises mais exatas e imparciais da realidade, é predominante nas análises do Cade nos casos envolvendo tabela médica. Tal teoria não apenas fornece o referencial teórico - com suas noções de "jogo do livre mercado", "forças de oferta e demanda", "mecanismos naturais de formação de preços", "eficiência", etc. - em detrimento de uma abordagem jurídica das regras que disciplinam a defesa da concorrência no Brasil, como se revela mesmo autossuficiente para a jurisprudência dominante da autoridade, a qual aparenta considerar desnecessário sequer checar se as hipóteses apresentadas pela teoria em tela têm algum respaldo nos fatos analisados $^{132}$.

\subsubsection{Jurisprudência do Cade acerca de tabelas médicas: algumas conclusões}

A análise jurisprudencial do Cade sobre tabelas médicas revela que a orientação majoritária da autoridade é no sentido de acolher argumentos lastreados estritamente -

\footnotetext{
${ }^{132}$ Vale mencionar que, embora haja na doutrina concorrencial uma discussão a respeito de quais condutas devem ser consideradas ilícitos pelo objeto e ilícitos pelos efeitos, não considero que tal discussão se aplique ao quanto analisado no presente trabalho. Isso porque, conforme esclarece o Conselheiro Marcos Paulo Veríssimo no PA n ${ }^{\circ}$ 08012.006923/2002-18, mesmo ilícitos por objeto não envolvem presunções absolutas de ilicitude, as quais independem de qualquer consideração a respeito dos efeitos de uma dada conduta. Tratam-se, na realidade, de presunções relativas de ilicitude, que podem e devem ser revistas mediante a apresentação de evidências em sentido contrário. Nos casos aqui examinados, o que se verifica é uma indiferença aos elementos e argumentos trazidos pelas partes à consideração da autoridade. A presunção de ilicitude das tabelas médicas é absoluta.
} 
ou, ao menos, preponderantemente - na teoria econômica. Conceitos e noções econômicas - como a capacidade de o livre mercado, através da atuação das forças de oferta e demanda, oferecer preços de equilíbrio que, por não serem impostos por nenhuma das partes, reflitam as particularidades do serviço prestado - são amplamente empregados como fundamento para as decisões pela ilicitude das tabelas, sem que haja uma verificação de se os pressupostos em que se baseiam esses conceitos guardam alguma correspondência com os fatos.

A despeito das constantes manifestações das representadas e mesmo de alguns conselheiros chamando a atenção para a necessidade de se atentar para outros elementos - tais como fatos e critérios propriamente jurídicos - na análise de legalidade das tabelas médicas, as decisões aqui examinadas estão amplamente amparadas na racionalidade da teoria econômica, a qual é considerada, inclusive, abstratamente.

Diante da força desses argumentos abstratos e autossuficientes, as ponderações propriamente jurídicas são negligenciadas ou mesmo informadas por critérios econômicos. Evidência disso é que, em alguns casos, a própria noção de licitude é absolutamente identificada com a noção de eficiência. 


\section{Conclusão}

O presente trabalho buscou explorar como se dá a relação entre direito e teoria econômica na aplicação do direito antitruste brasileiro. Para tanto, optou-se por analisar a jurisprudência do Cade sobre a adoção, sugestão de uso ou imposição de tabelas médicas por entidades representativas de profissionais desse ramo, cooperativas ou clínicas médicas.

Antes, porém, de se debruçar sobre as decisões da autoridade concorrencial a respeito desse tema, procurou-se apresentar os pressupostos teóricos que dão base à análise jurisprudencial. Mais precisamente, apresentou-se, em primeiro lugar, a relação histórica entre direito e teoria econômica no controle concorrencial, passando pelos diferentes objetivos já atribuídos à defesa da concorrência e pelos diferentes papéis que foram desempenhados por essas disciplinas, ao longo do tempo.

Conforme se pôde observar, a relação em tela é dinâmica e, embora o argumento de cunho econômico tenha ganhado bastante relevância há algumas décadas, a própria história da defesa da concorrência revela que a preponderância desse argumento sobretudo do argumento econômico pautado em uma única teoria - sobre argumentos de caráter político-valorativo (na elaboração, por exemplo, da legislação sobre a matéria) ou jurídico (na aplicação do direito antitruste) não reflete uma verdade necessária.

Feito isso, o trabalho se voltou a explorar como o direito e a teoria econômica no controle antitruste podem ser compreendidos como searas autônomas, mas que, ainda assim, se comunicam. Para tanto, fez-se uso da teoria dos sistemas de Luhmann, segundo o qual, há, na sociedade moderna, sistemas parciais que desempenham funções específicas para o sistema mais abrangente de todos, a própria sociedade. O sistema jurídico, como sistema parcial funcional, desempenha a função de garantia das expectativas normativas generalizadas, através da proteção de direitos.

Conforme se procurou explicar, longe de defender um autismo de cada sistema, a teoria luhmanniana sustenta que os sistemas podem, através de acoplamentos estruturais se relacionar com seu ambiente e com ele aprender. Também Faro de Castro argumenta que esse aprendizado mútuo, através da interdisciplinaridade, é benéfico. Para ele, a interação entre disciplinas é fundamental para combater um problema que identifica no direito brasileiro: o conceitualismo. Fazendo referência a esse espaço para o aprendizado e mesmo para o fortalecimento de cada sistema (ou disciplina), o trabalho em tela buscou 
explorar como a histórica e intrínseca relação entre o direito e a teoria econômica na defesa da concorrência pode ser compreendida como algo benéfico para ambos os ramos.

Por outro lado, apesar de benéfica, a relação entre sistemas possui limites os quais devem ser respeitados, de modo a garantir que a referida autonomia reste preservada. Isso se aplica também, naturalmente, à relação entre direito e teoria econômica no controle antitruste.

Para esclarecer os limites dessa relação específica, o trabalho se debruçou tanto sobre as próprias limitações da teoria econômica - as quais não são tão objetivas, neutras, completas e autossuficientes como os defensores da Escola Neoclássica de Chicago muitas vezes gostam de fazer crer -, quanto sobre a elementaridade do direito para o controle antitruste. Isso porque, nos moldes do que fora anteriormente apresentado, o sistema jurídico tem como importante função a proteção de direitos e não se pode substituir seus critérios de análise, sua racionalidade, sem comprometer, concomitantemente, o desempenho dessa função.

Mesmo diante dessas considerações - e da subsequente conclusão de que é necessário se proceder de maneira cautelosa ao operacionalizar a relação em questão - o diagnóstico de muitos autores, conforme demonstrado, é de que a teoria econômica figura, atualmente, no Brasil, assim como em outras jurisdições, como o único critério considerado válido a orientar o direito antitruste.

A segunda parte desse trabalho se dedicou, então, a verificar se tal avaliação procede, no que diz respeito à jurisprudência do Cade sobre tabelas médicas. Contudo, antes de adentrar a análise jurisprudencial, buscou-se delinear como o mercado de saúde suplementar está estruturado no País, como se dá seu funcionamento e quais são suas características particulares. Afinal, normas aplicadas a mercado abstratos não lidam de fato com os problemas que visam a solucionar e a defesa da concorrência - assim como sua implementação através da aplicação do direito concorrencial - não existe num vácuo, mas se destina a realidades específicas, que devem ser consideradas quando da aplicação das normas.

É nesse sentido que o trabalho verificou que, além de padecer das características comuns ao setor de saúde suplementar em geral, com suas falhas de mercado, o setor de saúde suplementar no País, pela própria maneira como está regulamentado, possui incentivos à concentração. Tais incentivos, conforme evidenciam os dados sobre o setor, 
têm se concretizado, de modo que há, hoje, no Brasil, um pequeno número de operadoras com uma parcela substancial do número de beneficiários totais. Outro importante dado sobre o setor é o fato de que a grande maioria dos beneficiários contrata planos de saúde via pessoas jurídicas (através de planos coletivos empresariais ou por adesão), indicando uma tendência dominante no sentido de o consumidor não negociar a contratação desses serviços individualmente, o que, por sua vez, tende a lhe empoderar nessa transação.

Assim, após ter apresentado um sucinto histórico sobre o mercado de saúde complementar no Brasil e analisado as características do setor - a quais deveriam servir para contextualizar o exame das decisões da autoridade - o trabalho se voltou à análise da jurisprudência do Cade.

Tal análise revelou que a linha argumentativa prevalecente na jurisprudência da autoridade sobre tabelas médicas se baseia quase que estritamente em argumentos de teoria econômica. Nesse sentido, conceitos e noções decorrentes dessa teoria - tais como, "jogo do livre mercado", "forças de oferta e demanda", "mecanismos naturais de formação de preços" e "eficiência" - despontam como os critérios determinantes para estabelecer a licitude ou, contrariamente, a ilicitude das tabelas médicas.

Verificam-se alguns posicionamentos questionando a correspondência dos argumentos derivados da teoria econômica com a realidade do funcionamento do mercado de saúde suplementar. Do mesmo modo, ponderações sobre questões de direito são aventadas por alguns conselheiros, que demandam que argumentos e raciocínios jurídicos sejam propriamente considerados na análise das condutas. No entanto, tais colocações são minoritárias e normalmente isoladas ao longo da jurisprudência. Os modelos econômicos - com suas formas sem muitas arestas e, portanto, capazes de fornecer respostas mais certas do que as que podem ser dadas através das discussões sobre o conteúdo de normas e princípios jurídicos-são o norte da análise do Cade no que tange a tabelas médicas. Ao aplicá-los, a autoridade normalmente não se atenta nem para as questões de fato trazidas pelas partes, nem para as questões de direito por vezes suscitadas por alguns conselheiros. Em alguns casos, mesmo, algumas peculiaridades do mercado são mencionadas pelos conselheiros, apenas para serem absolutamente ignoradas por eles próprios, na sequência.

Conforme já mencionado tantas vezes, o presente trabalho não se volta à análise do mérito ou validade dos argumentos econômicos ou jurídicos invocados pelo Cade em 
suas decisões. Logo, não se quer aqui contestar a correção das condenações ou dos arquivamentos dos casos de tabela médica. Questiona-se, isso sim, a maneira pela qual a autoridade tem procedido à análise desses casos, ignorando questões de direito ou mesmo esvaziando seu conteúdo em benefício de conteúdos ou racionalidades econômicas. As decisões calcadas predominantemente em análises de custo-benefício, na aferição de eficiências e em modelos abstratos sobre o funcionamento dos mercados não parece atentar para o fato de que esses critérios, ainda que possam informar o direito concorrencial, não são os únicos a fazê-lo. O direito concorrencial, enquanto ramo do sistema jurídico, se insere num ordenamento composto por normas e princípios que devem necessariamente ser considerados quando da aplicação desse direito.

Tendo em mente o que foi apresentado na primeira parte do presente trabalho, o que se verifica é que os limites da interdisciplinaridade entre direito e teoria econômica são, na análise dos casos de tabela médica, desrespeitados de maneira contumaz. A identificação da noção de licitude com a de eficiência talvez seja o exemplo mais gritante de como o próprio código binário do sistema jurídico se encontra comprometido. Afinal, a regra de duplicação "lícito/ilícito" é não raro retratada como mero reflexo da duplicação “eficiente/ineficiente". Nesse contexto, difícil imaginar que subsista um acoplamento estrutural, por meio do qual direito e teoria econômica se relacionam, mas preservam sua autonomia. O que parece ocorrer, pelo contrário, é a corrupção, a colonização, da racionalidade jurídica, pela econômica.

Mais uma vez: não se quer aqui argumentar que, caso se tivesse considerado os elementos jurídicos dos casos apreciados, as decisões do Cade teriam sido num sentido diverso do que o foram. Isso foge ao escopo do presente trabalho. O que se defende é que os aspectos jurídicos - assim como os fatos concretos que fornecem a eles e à teoria econômica substrato para análise - são essenciais à análise antitruste e não podem ser negligenciados. Conforme apresentado, não se pode prescindir da racionalidade e do conteúdo jurídico sem abrir mão, concomitantemente, dos direitos por eles resguardados. Nesse sentido, a lógica decisória do Cade, mais do que impactar os médicos, suas entidades representativas ou as operadoras de uma ou de outra forma, preocupa por minar a própria autonomia do sistema jurídico.

Os argumentos em prol da interdisciplinaridade entre direito e teoria econômica permanecem, naturalmente, válidos. Afinal, tal interação entre esses sistemas tem, de fato, o benefício de promover o aprendizado, a transformação e o próprio fortalecimento 
de cada um deles. Ademais, nos moldes do apontado por Castro (2012), o diálogo entre disciplinas pode ser uma forma de proteger o direito contra abordagens altamente abstratas, descoladas da realidade sobre a qual incide.

No entanto, nos casos aqui examinados, não se observa que a utilização da teoria econômica tenha levado a um maior engajamento com os fatos. Pelo contrário, as formas econômicas são empregadas abstratamente, de modo que sua "aplicação" aos casos não envolve nenhuma contraposição da teoria aos fatos concretos.

Consequentemente, o que se conclui a partir da análise da jurisprudência do Cade sobre tabelas médicas, é que o modo pelo qual a autoridade vem, de maneira geral, deliberando sobre o assunto, ao mesmo tempo em que não garante uma abordagem menos formalista e reificante do direito concorrencial, acaba por minar a racionalidade jurídica que deveria reger esse último. O resultado disso é um enfraquecimento do próprio sistema jurídico - ou, ao menos, do direito concorrencial - cuja importante função é a proteção de direitos. 


\section{Referências Bibliográficas}

ALMEIDA, S. F. Poder Compensatório e Política de Defesa da Concorrência: referencial geral e aplicação ao mercado de saúde suplementar brasileiro. Tese de doutorado. Escola de Economia de São Paulo da Fundação Getúlio Vargas. Prof. Orientador: Paulo Furquim de Azevedo. 2009. Disponível em: http://bibliotecadigital.fgv.br/dspace/bitstream/handle/10438/4259/Silvia_Faga_Almeid a_2009.pdf? sequence=4\&isAllowed=y. Acesso em 25 Novembro 2015.

ALMEIDA, S. F.; AZEVEDO, P. F. Cooperativas Médicas: ilícito antitruste ou ganho de bem-estar? Textos para Discussão 263, Escola de Economia de São Paulo/FGV. São Paulo: Fundação Getúlio Vargas, julho de 2010. Disponível em: http://bibliotecadigital.fgv.br/dspace/bitstream/handle/10438/6894/TD\%20263\%20\%20S\%C3\%ADlvia\%20Fag\%C3\%A1\%20de\%20Almeida.pdf?sequence=1\&isAllowed =y. Acesso em: 25 Novembro 2015.

ARROW, K. J. Uncertainty and the welfare economics of medical care. The American Economic Review. Vol. LIII, No. 5, December 1963, p. 941-973.

BAIN, J. S. Economies of Scale, Concentration, and the Condition of Entry in Twenty Manufacturing Industries. The American Economic Review, 1954, vol. 44, no 1, p. 1539. Disponível em: 〈http://www.jstor.org/stable/1803057〉. Acesso em: 15 Agosto 2014.

BAKER, J. A Preface to post-Chicago Antitrust. In: Post-Chicago Developments in Antitrust Law, p. 60-75. Edward Elgar Publishing, 2002.

BORK, R. H. Legislative Intent and the Policy of the Sherman Act. Journal of Law and Economics, p. 7-48, Outubro de 1966.

BRASIL. Agência Nacional de Saúde Suplementar. Caderno de Informação da Saúde Suplementar: beneficiários, operadoras e planos. Rio de Janeiro: ANS, junho de 2014. . Resolução Normativa n 39, de 29 de maio de 2003.

. Resolução Normativa n 137 , de 14 de novembro de 2006.

. Resolução Normativa nº 195 de 14 de julho de 2009.

. Resolução Normativa n ${ }^{\circ} 196$ de 14 de julho de 2009.

BRASIL. Conselho Administrativo de Defesa Econômica. AC no 08700.004065/201291; PA n ${ }^{\circ} 156 / 94$; PA no 174/94; PA no 173/94; PA n ${ }^{\circ} 158 / 94$; PA no 08000.011519/9461; PA n ${ }^{\circ} 08000.011520 / 94-40$; PA n ${ }^{\circ} 08000.027395 / 95-80$; PA n ${ }^{\circ} 08000.010 .318 / 94-$ 73; $\mathrm{PA} \mathrm{n}^{\circ} 08000.011518 / 94-06$; $\mathrm{PA} \mathrm{n}^{\circ} 08000.022630 / 97-52$; $\mathrm{PA} \mathrm{n}^{\circ} 08012.007460 / 97-74$; $\mathrm{PA} \mathrm{n}^{\circ}$ 08000.012252/94-38; PA n ${ }^{\circ} 08000.021054 / 96-27$; $\mathrm{PA} \mathrm{n}^{\circ} 08000.020425 / 96-71$; PA $\mathrm{n}^{\circ}$ 08012.021738/96-92; PA n ${ }^{\circ} 08012.006397 / 97-02$; PA n ${ }^{\circ} 08000.021976 / 97-51 ;$ PA $^{\circ}$ 08012.001098/01-84; PA n 08012.003664/01-92; PA no 08000.011522/94-75; PA n ${ }^{\circ}$ 08000.005351/97-42; PA no 08012.002153/00-72; PA n 08012.007042/01-33; PA n ${ }^{\circ}$ 08000.020294/96-03; PA n 08012.005194/01-00; PA no 08012.008060/04-85; PA n ${ }^{\circ}$ 08000.013470/95-25; PA no 08000.015228/94-60; PA no 08000.011516/94-72; PA n ${ }^{\circ}$ 
08012.014463/07-14; PA no 08012.006552/05-17; PA n 08012.005644/04-07; PA no 08012.005135/05-57; PA no 08012.006552/05-17; PA n 08012.008477/04-48; PA no 08012.007833/06-78; $\mathrm{PA} \mathrm{n}^{\circ} 08012.005374 / 02-64 ; \mathrm{PA} \mathrm{n}^{\circ} 08012.006552 / 05-17$; $\mathrm{PA} \mathrm{n}^{\circ}$ 08012.007833/06-78; PA n 08012.001790/04-55; PA n 08012.003048/03-01; PA n ${ }^{\circ}$ 08012.007042/01-33; PA n 08000.020294/96-03; PA n 08012.010703/94-84; PA no 08012.006923/02-18; PA n ${ }^{\circ} 08012.003048 / 03-01$; $\mathrm{PA} \mathrm{n}^{\circ}$ 61/92; $\mathrm{PA} \mathrm{n}^{\circ} 08000.007201 / 97$ 09; $\mathrm{PA} \mathrm{n}^{\mathrm{o}} 08012.007033 / 06-57$

BRASIL. Conselho Nacional de Secretários de Saúde. Saúde Suplementar. Coleção Progestores - Para entender a gestão do SUS, 11. Brasília: CONASS, 2007. 243 p. Disponível em: http://bvsms.saude.gov.br/bvs/publicacoes/colec_progestores_livro11.pdf. Acesso em 25 Novembro 2015.

BRASIL. Constituição da República Federativa do Brasil. Brasília, DF: Senado Federal: Centro Gráfico, 1988. . Lei ${ }^{\circ} 5.764$ de 16 de dezembro de 1971. . Lei $\mathrm{n}^{\circ} 8.078$, de 11 de setembro de 1990. Lei $\mathrm{n}^{\circ}$ 9.656, de 3 de junho de 1998. . Lei $\mathrm{n}^{\circ} 10.185$ de 12 de fevereiro de 2001. . Lei $\mathrm{n}^{\mathrm{o}} 12.529$ de 30 de novembro de 2011.

CASTRO, Marcus Faro de. Dimensões Políticas e Sociais do Direito Sanitário Brasileiro. In: ARANHA, Márcio Iorio (org.). Direito Sanitário e Saúde Pública: coletânea de textos, Vol. I. Brasília: Ministério da Saúde. p. 363-374.

CASTRO, M. F. de. Formas jurídicas e mudança social: interações entre o Direito, a Filosofia, a Política e a Economia. 1. ed. São Paulo: Saraiva, 2012.

CHRISTIANSEN, A. 2006. The 'more economic approach' in EU merger control: A critical assessment. Research Notes 21e. Deutsche Bank Research. http://ideas.repec.org/p/zbw/dbrrns/21e.html

COOPER, J.; FROEB, L.; O'BRIEN, D.; VITA, M. 2005. Vertical Restrictions and Antitrust Policy: What about the Evidence? SSRN Scholarly Paper ID 825089. Vanderbilt Public Law Research Paper No. 05-32. Rochester, NY: Social Science Research Network. http://papers.ssrn.com/abstract=825089.

DEVLIN, A. J. Antitrust in an Era of Market Failure. Harvard Journal of Law and Public Policy, 2010, vol. 33, p. 557. Disponível em: <http://ssrn.com/abstract=1429539> Acesso em: 21/09/2014.

DILORENZO, T. J. The origins of Antitrust: An Interest-group Perspective. International Review of Law and Economics. George Mason University, 1985. 
FORGIONI, P. A. Os Fundamentos do Antitruste. 8. ed. São Paulo: Editora Revista dos Tribunais LTDA, 1998.

FRAZÃO, A. de O. A necessária constitucionalização do Direito da Concorrência. Direitos fundamentais e jurisdição constitucional. 1. ed. São Paulo: Editora Revista dos Tribunais, 2014, vol. 1, p. 139-158.

FREDERICK, D. Antitrust status of farmer cooperatives the story of the CapperVolstead Act. U.S. Dept. of Agriculture, Rural Business-Cooperative Service, 2002.

GABAN, E. M.; DOMINGUES, J. O. Direito Antitruste. 3. ed. São Paulo: Saraiva, 2012.

GOLDBERG, D. K. Antitruste e a Barganha Coletiva no Mercado de Saúde Suplementar. In: MATTOS, C. (coord.). A revolução do antitruste no Brasil: A teoria econômica aplicada a casos concretos. São Paulo: Singular, 2008, p. 329-355.

GUERRA FILHO, W. S. Autopoiese do Direito na Sociedade Pós-Moderna: introdução a uma teoria social sistêmica. 1. ed. Porto Alegre: Livraria do Advogado, 1997.

HEYER, K. 2005. A World of Uncertainty: Economics and the Globalization of Antitrust. Antitrust Law Journal 72 (2): 375-422.

HOVENKAMP, H. Federal Antitrust Policy: The Law of Competition and Its Practice. 3. ed. West Group, 2005.

The Antitrust Movement and the Rise of Industrial Organization.

Texas Law Review, 1989, vol. 68, p. 105. Disponível em: <http://ssrn.com/abstract=1414452>. Acesso em: 22/08/2014.

KOVACIC, W.; SHAPIRO, C. Antitrust Policy: A Century of Economic and Legal Thinking. Journal of Economic Perspectives, 2000, vol. 14, nº 1, p. 43-60.

KRATTENMAKER, T.; LANDE, R.; SALOP S. Monopoly Power and Market Power in Antitrust Law. Georgetown Law Journal, 1987, p. 241-269.

LANDE, R. H. A traditional and textualist analysis of the goals of antitrust: efficiency, preventing theft from consumers, and consumer choice. Fordham Law Review, vol. 81, issue 5, article 8, 2003.

LUHMANN, N. Social Systems. Stanford: Stanford University Press, 1997.

Operational Closure and Structural Coupling: the differentiation of the Legal System. Cardoso Law Review, 13, p. 1419-1441, 1992.

La Sociedad de la sociedad. 1. ed. Herder, México, 2007.

. The Unity of the Legal System. In: "Autopoietic Law: A New Approach to Law and Society. European University Institute, De Gruyter, 1987, p. 12-36. 
MARSHALL, A. Principles of Economics. Cambridge: Cambridge University Press, 2013.

MATTHEIS, C. The System Theory of Niklas Luhmann and the Contitutionalization of the World Socitey. Goettingen Journal of International Law, no 4, p. 626-647, 2012.

MESTMÄCKER, H.J. Markt-Recht-Wirtschaftsverfassung. In: Zeitschrift für das gesamte Handelsrecht und Wirtschaftsrecht 137, pp. 97 e ss, 1973.

MOTTA, M. Competition Policy: Theory and Practice. Cambridge: Cambridge University Press, 2004.

NEVES, M. Entre Têmis e Leviatã: uma relação difícil: o Estado Democrático de Direito a partir e além de Luhmann e Habermas. 1. ed. São Paulo: Martins Fontes, 2006.

NEVES, M. Pesquisa Interdisciplinar no Brasil o Paradoxo da interdisciplinaridade. Revista do Instituto de Renneneutica Juridica. Vol. J, n. 3, 2005.

Entre Subintegração e Sobreintegração: A Cidadania Inexistente. Revista de Ciências Sociais, vol. 37, nº 2, pp. 253-276, 1994.

OLIVEIRA, G.; RODAS, J. G. Direito e Economia da Concorrência. 2. ed. São Paulo: Editora Revista dos Tribunais LTDA, 2013.

PEREIRA, C., O Marco Regulatório do Setor de Saúde Suplementar: Contextualização e Perspectiva. Fórum de Saúde Suplementar, Rio de Janeiro. 2003.

PITOFSKY, R. The Political Content of Antitrust. University of Pennsylvania Law Review, vol. 127, nº 4, 1979.

RAGAZZO, Carlos Emmanuel Joppert; MACHADO, Kenys Menezes. Desafios da Análise do CADE no Setor de Planos de Saúde. In: PERILLO, Eduardo Bueno da Fonseca; AMORIM, Maria Cristina Sanches. (Org.). Para entender a saúde no Brasil 4. 1ed. São Paulo: LCTE, 2011, p. 203-234

RODRIGUES, L. P.; NEVES F. M. Niklas Luhmann: a sociedade como sistema. 1. ed. Porto Alegre: EDIPUCRS, 2012.

SALAZAR, A.L.; RODRIGUES, K.; NUNES JÚNIOR, V.S. Assistência privada à saúde: regulamentação, posição do IDEC e reflexos no sistema público. In: ARANHA, Márcio Iorio (org.). Direito Sanitário e Saúde Pública: coletânea de textos, Vol. I, Brasília: Ministério da Saúde. pp. 333-362.

SALOMÃO FILHO, C. Direito Concorrencial: as condutas. 1. ed. São Paulo: Malheiros Editores, 2003.

. Direito Concorrencial: as estruturas. 3. ed. São Paulo: Malheiros Editores, 2007. 
. A paralisia do antitruste. In: GABAN, E. M.; DOMINGUES, J. O. (coord.)

Estudos de Direito Econômico e Economia da Concorrência. 1. ed. Curitiba: Juruá Editora, 2009.

Revolution through Law in the Economic Sphere. Seminario en Latinoamérica de Teoría Constitucional y Política, Paper 10, 2002.

SANTACRUZ, R. Regulação e Concentração no Mercado Brasileiro de Saúde Suplementar. In: FARINA, L; GUIMARÃES, D. A. (org.). Concorrência e regulação no setor de saúde suplementar. São Paulo: Singular, 2010, pp. 109-167.

SECRETARIA DE ACOMPANHAMENTO ECONÔMICO (SEAE/MF). Guia para análise econômica de atos de concentração horizontal. Portaria Conjunta SEAE/SDE $\mathrm{n}^{\circ} 50$, de 1 de agosto de 2001.

SCHUARTZ, L. F. Quando o Bom é o Melhor Amigo do Ótimo: a autonomia do direito perante a economia e a política da concorrência. Revista de Direito Administrativo, 245, Maio-Agosto, 2007, pp. 98-99 e 110.

A desconstitucionalização do direito de defesa da concorrência. FGV, Sistema de Bibliotecas, Direito Rio, Textos para discussão, 14/10/2008.

STIGLITZ J.E.; WALSH, C.E. Introdução à Microeconomia (tradução da $3^{a}$ edição americana) Rio de Janeiro: Elsevier Editora, 2003.

STUCKE, M. E. Reconsidering Antitrust's Goals. Boston College Law Review, vol. 53, p. 551, 2012. Disponível em: <http://ssrn.com/abstract=1904686>. Acesso em: 22/06/2014.

TEUBNER, G. Altera Pars Audiatur: o direito na colisão de discursos. In: LINDGREN ALVES, J. A. (org.). Direito e Cidadania na Pós-modernidade. Piracicaba, Editora Unimep, 2002, p. 93 e ss.

VIANNA, C. M. de M. O Impacto das Ações da Agência Nacional de Saúde Suplementar - ANS - no Mercado Operador. In: BRASIL, Ministério da Saúde. Regulação \& Saúde Vol. 3: Documentos técnicos de apoio ao Fórum de Saúde Suplementar de 2003, Tomo 1. Rio de Janeiro: Ministério da Saúde, 2004, p. 333-357.

WISH, R. Competition Law. 5. ed. Oxford: Oxford University Press, 2005. 